\title{
Heteropoda Latreille, 1804: new species, synonymies, transfers and records (Araneae: Sparassidae: Heteropodinae)
}

\author{
Heteropoda Latreille, 1804: новые виды, синонимия, комбинации \\ и находки (Araneae: Sparassidae: Heteropodinae)
}

\author{
Peter Jäger \\ П. Ягер
}

Arachnology, Senckenberg Research Institute, Senckenberganlage 25, 60325 Frankfurt am Main, Germany. E-mail: peter. jaeger@senckenberg.de

KEY WORDS: Huntsman spiders, Southeast Asia, systematics, revision.

КЛЮЧЕВЫЕ СЛОВА: пауки-спарассиды, Юго-Восточная Азия, систематика, ревизия.

ABSTRACT. The genus Heteropoda Latreille, 1804 is revised by means of original descriptions and respective type material as well as of material recently received. Seven new species are described: $H$. pekkai sp.n. from Bhutan ( + ), $H$. opo sp.n. from caves in Burma (+), H. cece sp.n. from a cave in Indonesia, Kalimantan $\left(\sigma^{7}\right), H$. duo sp.n. $\left(\sigma^{7}\right)$ from Indonesia, Kalimantan, H. kusi sp.n. from a cave in Indonesia, Kalimantan $\left(\sigma^{\top}+\right)$, H. maukin sp.n. from a cave in Indonesia, Kalimantan (+), H. obe sp.n. from a cave in Indonesia, Sulawesi $\left(\sigma^{7}+\right)$. Lectotypes are designated for: H. mediocris Simon, 1887 (†); H. kobroorica Strand, 1911 ( + ). Redescriptions are provided for: $H$. listeri Pocock, 1900 from $\sigma^{r}$ and $O$ syntypes from Christmas Island; H. nigriventer Pocock, 1897 from recently collected material from Central Sulawesi; $H$. mediocris Simon, 1887 from female lectotype from New Guinea; H. languida Simon, 1887 from + holotype from Burma; H. kabaenae Strand, 1911 from $ᄋ$ holotype from Indonesia, Sulawesi; $H$. analis Thorell, 1881 from $\rightarrow$ holotype from Fly River, Papua New Guinea. Following new synonymies are proposed: $H$. kobroorica Strand, 1911. syn.n. with $H$. analis Thorell 1881; H. regalis Roewer, 1938, syn.n. with $H$. mediocris; $H$. laurae Jäger, 2008 syn.n. with $H$. nigriventer Pocock, 1900; Ocypete thoracica C.L. Koch, 1845, syn.n., Sarotes aulicus L. Koch, 1878, syn.n., Sarotes truncus McCook, 1878, syn.n., H. venatoria japonica Strand, 1907, syn.n., H. venatoria chinesica Strand, 1907, syn.n., H. venatoria maculipes Strand, 1907, syn.n., H. nicki Strand, 1915, syn.n., H. nicki quala Strand, 1915, syn.n., H. tokarensis Yaginuma, 1961, syn.n., H. andamanensis Tikader, 1977, syn.n., H. nicobarensis Tikader, 1977, syn.n. and H. hainanensis Li, 1991, syn.n. with Heteropoda venatoria (Linnaeus, 1767). The following new combinations are established: Heteropoda megalopis (Thorell, 1891) comb.n. (ex Spariolenus Simon, 1880); Barylestis manni (Strand, 1906) comb.n., Pseudopoda aureola (He et Hu, 2000) comb.n., Pseudopoda shillongensis (Sethi et Tikader,
1988) comb.n., Pseudopoda straminiosa (Kundu, Biswas et Raychaudhuri, 1999) comb.n., Gnathopalystes denticulatus Saha et Raychaudhuri, 2007 comb.n., Olios bhattacharjeei Saha et Raychaudhuri, 2007 comb.n., Olios debalae (Biswas et Roy, 2005) comb.n., Spariolenus buxa (Saha, Biswas et Raychaudhuri, 1995) comb.n. (all ex Heteropoda). Heteropoda camelia Strand, 1914 belongs not to Heteropoda, but to an unrecognisable genus of Sparassidae. Biswas \& Raychaudhuri [2005] illustrate not a $H$. venatoria, but an unidentifiable species of Sparassidae. The following species described from juveniles are considered nomina dubia: $H$. annulipoda Strand, 1911 from Aru Islands, $H$. bimaculata Thorell, 1878 from Ambon, $H$. bivittata Thorell, 1887 from Sulawesi, H. megalopis (Thorell, 1891) from Nicobar Islands, and $H$. panaretiformis Strand, 1906 from Sumatra. Heteropoda zuviele Jäger, 2008 and H. simplex Jäger et Ono, 2000 are recorded the first time from Taiwan, H. boiei (Doleschall, 1859) from Borneo, H. parva Jäger, 2000 from Kalimantan and Sarawak. Heteropoda beroni Jäger, 2005 is recorded from the cave Gua Istani Taokala (Sulawesi, Maros karst, Bantimurung). Heteropoda sp. cf. sumatrana Thorell, $1890(+)$ is recorded from Java, Cibodas, described and illustrated.

РЕЗЮМЕ. Ревизован род Heteropoda Latreille, 1804: приведены оригинальные описания, исследованы типовые экземпляры, изучены новые материалы. Описано 7 новых видов: H. pekkai sp.n. (Бутан, †), H. оро sp.n. (пещера в Бирме, +), Н. сесе sp.n. (пещера в Индонезии, Калимантан, О), H. duo sp.n. (Индонезия, Калимантан, $\sigma^{7}$ ), H. kusi sp.n. (пещера в Индонезии, Калимантан, О’ + ), H. maukin sp.n. (пещера в Индонезии, Калимантан, +), H. obe sp.n. (пещера в Индонезии, Сулавеси, О' $)$ ). Выделены лектотипы для: H. mediocris Simon, 1887 (†); H. kobroorica Strand, 1911 (†). Переописаны: H. listeri Pocock, 1900 по синтипам $\sigma^{7}$ и + с о. Рождества; $H$. nigriventer Pocock, 1897 на основе недавно собран- 
ного материала из центрального Сулавеси; Н. mеdiocris Simon, 1887 по лектотипу + из Новой Гвинеи; H. languida Simon 1887 по голотипу ф из Бирмы; H. kabaenae Strand, 1911 по голотипу ф из Индонезии, Сулавеси; H. analis Thorell, 1881 по голотипу с Fly River, Папуа Новая Гвинея. Установлена новая синонимия: H. kobroorica Strand, 1911 , syn.n. $=H$. analis Thorell, $1881 ; H$. regalis Roewer, 1938, syn.n. $=H$. mediocris; H. laurae Jäger, 2008 syn.n. $=$ H. nigriventer Pocock, 1900; Ocypete thoracica C.L. Koch, 1845, syn.n., Sarotes aulicus L Koch, 1878, syn.n., Sarotes truncus McCook, 1878, syn.n., H. venatoria japonica Strand, 1907, syn.n., H. venatoria chinesica Strand, 1907, syn.n., H. venatoria maculipes Strand, 1907, syn.n., H. nicki Strand, 1915, syn.n., H. nicki quala Strand, 1915, syn.n., H. tokarensis Yaginuma, 1961, syn.n., H. andamanensis Tikader, 1977, syn.n., H. nicobarensis Tikader, 1977, syn.n. и H. hainanensis Li, 1991, syn.n. = Heteropoda venatoria (Linnaeus, 1767). Установлены следующие новые комбинации: Heteropoda. megalopis (Thorell, 1891) comb.n. (ex Spariolenus Simon, 1880); Barylestis manni (Strand, 1906) comb.n., Pseudopoda aureola (He et Hu, 2000) comb.n., Pseudopoda shillongensis (Sethi et Tikader, 1988) comb.n., Pseudopoda straminiosa (Kundu, Biswas et Raychaudhuri, 1999) comb.n., Gnathopalystes denticulatus Saha et Raychaudhuri, 2007 comb.n., Olios bhattacharjeei Saha et Raychaudhuri, 2007 comb.n., Olios debalae (Biswas et Roy, 2005) comb.n., Spariolenus buxa (Saha, Biswas et Raychaudhuri, 1995) comb.n. (все ex Heteropoda). Heteropoda camelia Strand, 1914 принадлежит не к роду Heteropoda, а к роду Sparassidae, который невозможно идентифицировать. Biswas \& Raychaudhuri [2005] проиллюстрировали не $H$. venatoria, a не определяемый по рисунку вид of Sparassidae. Ряд видов, описанных по неполовозрелым особям считаются nomina dubia: $H$. annulipoda Strand, 1911 (о-ва Аpy), H. bimaculata Thorell, 1878 (Амбон), H. bivittata Thorell, 1887 (Сулавеси), H. megalopis (Thorell, 1891) (Никобарские о-ва) и H. panaretiformis Strand, 1906 (Суматра). Heteropoda zuviele Jäger, 2008 и H. simplex Jäger et Ono, 2000 впервые отмечены на Тайване, H. boiei (Doleschall, 1859) — на Борнео, H. parva Jäger, 2000 на Калимантане и в Сараваке. Heteropoda beroni Jäger, 2005 отмечена в пещере Gua Istani Taokala (Сулавеси, карст Maros, Bantimurung). Heteropoda sp. cf. sumatrana Thorell, 1890 (†) отмечена на Яве, Cibodas, описана и проиллюстрирована.

\section{Introduction}

Heteropoda Latreille, 1804 is a large genus of huntsman spiders almost exclusively distributed in Asia and Australia. Currently 225 species and subspecies are known [Platnick, 2013], eight of which are considered nomina dubia. Four of those plus additional three species listed as valid are occurring outside of the distribution range of the genus making them likely either syn- onyms of the pantropical $H$. venatoria (Linnaeus, 1767) or are to be transferred to other genera. Another species, $H$. pumilla Keyserling, 1880, was recently transferred to the genus Sparianthina Banks, 1929 [Jäger et al., 2009]. Seven species are described by juveniles only, thus have to be considered nomina dubia thinking of the huge amount of mostly similar species in respect of somatic characters. In the present paper, 7 species are newly described, 15 are synonymised, 1 is transferred to Heteropoda and 8 are transferred to other genera, resulting in a current total of 211 valid Heteropoda species, including 15 nomina dubia.

Recently, Jäger [2008b] described 25 new Heteropoda species from Asia and Australia focussing on species with exceptional male palp conformations, e.g. of the Heteropoda javana-group. Eusemann \& Jäger [2009] recorded a high variation in one widely distributed species (H. tetrica). Jäger \& Bayer [2009] described two new species from Laos, and Bayer \& Jäger [2009] recorded the male of $H$. ocyalina (Simon, 1887) for the first time. In the meantime new material was trusted to the author and, additionally, type material of previously described species was either re-examined or examined for the first time resulting in new synonyms and redescriptions.

\section{Material and methods}

The examined spiders were preserved in 70\% denatured ethanol. Examination and drawings were carried out with a Leica MZ 16 stereomicroscope with camera lucida attachment. Female copulatory organs were dissected and the sclerotised internal duct system was cleared in $96 \%$ DL-lactic acid $\left(\mathrm{C}_{3} \mathrm{H}_{6} \mathrm{O}_{3}\right)$. All measurements are in $\mathrm{mm}$. Prosoma length/width means length/ width of the dorsal shield of prosoma. Leg formula, leg spination pattern and size classes follow Jäger [2001]. Palp and leg lengths are listed as: total (femur, patella, tibia, metatarsus, tarsus). Arising points of tegular appendages in males are described as clock-positions of the left pedipalp in ventral view. The part of the internal duct system with glandular pores is called "turning point", as at this point the duct system changes its direction. In schematic illustration of the courses it is marked with " $T$ ", the copulatory orifice with a circle, and the end of the fertilisation duct in direction of the uterus externus with an arrow. As in Jäger [2005: 88], slit sensilla close to the epigyne are illustrated as descriptive character.

Valid Heteropoda species are listed in order of their geographic appearance in South Asia, Southeast Asia and Papua New Guinea from West to East and North to South. Exception is H. venatoria, which is listed as pantropical type species first. At the end nomina dubia and species transferred to other genera are listed. Elevation is given in metres, indicated by adding an " $m$ " to the particular number. Geographic coordinates (and rough estimate of elevation) are given in square brackets when detected via Google Earth. Maps were produced with DIVA GIS version 7.5.0.0. Spe- 
cies groups are named and described if possible, if a certain set of characters occur steadily in some species and they can be considered belonging to one phylogenetic lineage. However, presently no statements about their systematic position can be made, i.e. which lineages are basal, which derived. Some species cannot be assigned to any distinct species-group. Some of them are recognised as being closely related to each other. In such cases a short paragraph in front of those species indicates shared characters. Formal species groups are not established in these cases, since character combinations and their consistency is too vague or there was not a sufficient amount of material available. Illustrations of some species have been made during visits in NHM or other large collections without taking exact measurements of all body parts partly due to their bad condition. Some of these specimens are nonetheless included since their types have never or only poorly been illustrated so far.

Abbreviations used in the text: ALE - anterior lateral eye; AME - anterior median eye; dRTA dorsal part/branch of RTA; PJ - numbers represent subsequent numbers of Sparassidae examined by the author; PLE - posterior lateral eye; PME — posterior median eye; RTA — retrolateral tibial apophysis; IIV - referring to leg numbers.

Terminology used in the text is explained in Figs 19. In other figures only exceptional or new features are indicated.

Museum collections (with curators): $\mathrm{AMNH}-$ American Museum of Natural History, New York (Norman Platnick); EZC — Entomological Laboratory, Department of Zoology, University of Calcutta (curator unknown); IRSN - Institut Royal des Sciences Naturelles de Belgique, Brussels (Leon Baert, Boudewijn Godeeris); IZCAS — Institute of Zoology, Academy of Sciences, Beijing (Shuqiang Li); MCSN - Museo Civico di Storia Naturale "Giacomo Doria", Genoa (Maria Tavano); MCZ - Museum of Comparative Zoology, Cambridge, Massachusetts (Gonzalo Giribet); MHNG - Museum d'Histoire de Naturelle, Geneve (Peter Schwendinger); MNHN - Muséum National d'Histoire de Naturelle, Paris (Christine Rollard); MZB - Museum Zoologicum Bogoriense, Jakarta (Yayuk R. Suhardjono); NHM - Natural History Museum, London (Janet Beccaloni); NHMB - Naturhistorisches Museum Basel (Ambros Hänggi); NHMW Naturhistorisches Musuem, Vienna (Christoph Hörweg); NMBE - Naturhistorisches Museum Bern (Christian Kropf); NSMT - National Science Museum, Tokyo (Hirotsugu Ono); NZSI - National Collection of the Zoological Survey of India, Calcutta (curator unknown); PPSG - Plant Protection Station of Ganzhou Prefecture, Jiangxi Province (Aihua Li); QMS - Queensland Museum, Brisbane (Robert Raven); RMNH - Nationaal Natuurhistorische Museum, Leiden (Jeremy Miller); SMF — Senckenberg Museum, Frankfurt (Peter Jäger); SMNS - Staatliches Museum für Naturkunde, Stuttgart (Joachim Holstein); TNHM - Tianjin Natural History Museum (curator unknown); WRSP - Western Regional Station, Zoological Survey, Poona (curator unknown); ZMB Zoologisches Museum, Berlin (Jason Dunlop); ZMUM - Zoological Museum of the University, Moscow (Kirill Mikhailov).

\section{Taxonomy}

Sparassidae Bertkau, 1872

Heteropodinae Thorell, 1873

Heteropoda Latreille, 1804

\section{Heteropoda venatoria (Linnaeus, 1767)} Figs 1-26.

Aranea venatoria Linnaeus, 1767: 1035, no. 33 (description; whereabouts of types from "America calidiore" [= warmer or tropical America] unknown, not in Linnean Society, London or NHM, London; most likely lost).

Ocypete thoracica C.L. Koch, 1845: 42, f. 982 (description of holotype $\sigma^{7}$, Java, Munich, types most likely lost). Heteropoda thoracica, - Thorell, 1878: 192, 273, 306 (description of $\sigma^{7}$; see note below). Syn.n.

Sarotes aulicus L. Koch, 1878: 766, pl. 16, f. 31 (description of ${ }^{\circ}$; $\rightarrow$ holotype not found). Syn.n.

Sarotes invictus L. Koch, 1878: 767, pl. 18, f. 32 (description of holotype + , PJ 470, Japan, Roretz A.-N. 20.II.1879, NHMW, Arachn. Inv. No. 17863, examined). Ono 2009: 473 (syn.).- Non(!) Bösenberg \& Strand, 1906: 275 (misidentification; $\sigma^{7}:$ Sinopoda forcipata; female: see Sarotes peditatus below).

Sarotes truncus McCook, 1878: 147, f. 2C (description of $q$; 9 holotype not found). Heteropoda truncus: Bösenberg \& Strand, 1906: 275 (assuming it is a Palystes according to Simon). Syn.n.

Sarotes peditatus Karsch, 1881: 38 (description of holotype + , PJ 3173, Japan, ZMB 3566, examined).

Heteropoda venatoria japonica Strand, 1907: 559 (description of $\sigma^{\gamma} ; \sigma^{7}$ syntypes, Japan, China, SMNS, destroyed in 2nd world war, Holstein, pers. comm.; not listed in Renner, 1988). Strand, 1909: 6. Syn.n.

Heteropoda venatoria chinesica Strand, 1907: 559 (description of holotype $\sigma^{7}$, China, SMNS, destroyed in 2 nd world war acc. to Renner [1988: 323]. Syn.n.

Heteropoda venatoria maculipes Strand, 1907: 559 (description of holotype $\sigma^{7}$, China, Guangdong Province, Fu Mui, SMNS, destroyed in 2nd world war, Holstein, pers. comm.; not listed in Renner [1988]. Syn.n.

Heteropoda nicki Strand, 1915: 246 (description of holotype + , PJ 230, Indonesia, E Java, SMF 4581, examined). Syn.n.

Heteropoda nicki quala Strand, 1915: 247 (description of holotype 9 , PJ 294, Indonesia, Sumatra, Bandar Kwala [= Bandar Kuala; $3^{\circ} 20^{\prime} 37.00^{\prime \prime} \mathrm{N}, 98^{\circ} 49^{\prime} 25.00^{\prime \prime} \mathrm{E}, 100 \mathrm{~m}$ ], SMF 4582, examined). Syn.n.

Heteropoda tokarensis Yaginuma, 1961: 84, f. G-L (description of $\sigma^{7}+$; $\sigma^{\top}$ holotype, 1 paratype, Japan, Nakanoshima Island

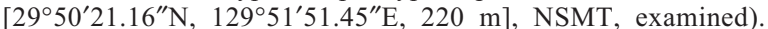
Syn.n.

Heteropoda andamanensis Tikader, 1977: 189, f. 16 A-E (description of $\sigma^{\top}+$; $q$ holotype: India, Andaman Islands, Long Island $\left[12^{\circ} 24^{\prime} 14.81^{\prime \prime} \mathrm{N}, 92^{\circ} 56^{\prime} 13.67^{\prime \prime} \mathrm{E}, 85 \mathrm{~m}\right]$ (holotype) and Havelock Island $\left[12^{\circ} 1^{\prime} 33.49^{\prime \prime} \mathrm{N}, 92^{\circ} 59^{\prime} 27.24^{\prime \prime} \mathrm{E}, 8 \mathrm{~m}\right]$ (paratype $\sigma^{7}$ ), WRSP, not examined). Sethi \& Tikader, 1988: 15, f. 40-45 (ㅇ). Syn.n.

Heteropoda nicobarensis Tikader, 1977: 191, f. 17 A-D (description of holotype $\rightarrow$, India, Nicobar Islands, Kamorta Island $\left[8^{\circ} 10^{\prime} 22.68^{\prime \prime} \mathrm{N}, 93^{\circ} 28^{\prime} 54.63^{\prime \prime} \mathrm{E}, 33 \mathrm{~m}\right]$, guest house, WRSP, not examined). Sethi \& Tikader, 1988: 28, f. 130-134 (). Syn.n.

Heteropoda hainanensis Li, 1991: 366, f. 1-4 (description of $\sigma^{7}$; $\sigma^{7}$ holotype, China, Hainan Province, Lingshui County [18 $\left.30^{\prime} 21.96^{\prime \prime} \mathrm{N}, 110^{\circ} 1^{\prime} 57.97^{\prime \prime} \mathrm{E}, 10 \mathrm{~m}\right]$, PPSG, not examined). Song et al., 1999: 467, f. 2680. Syn.n. 


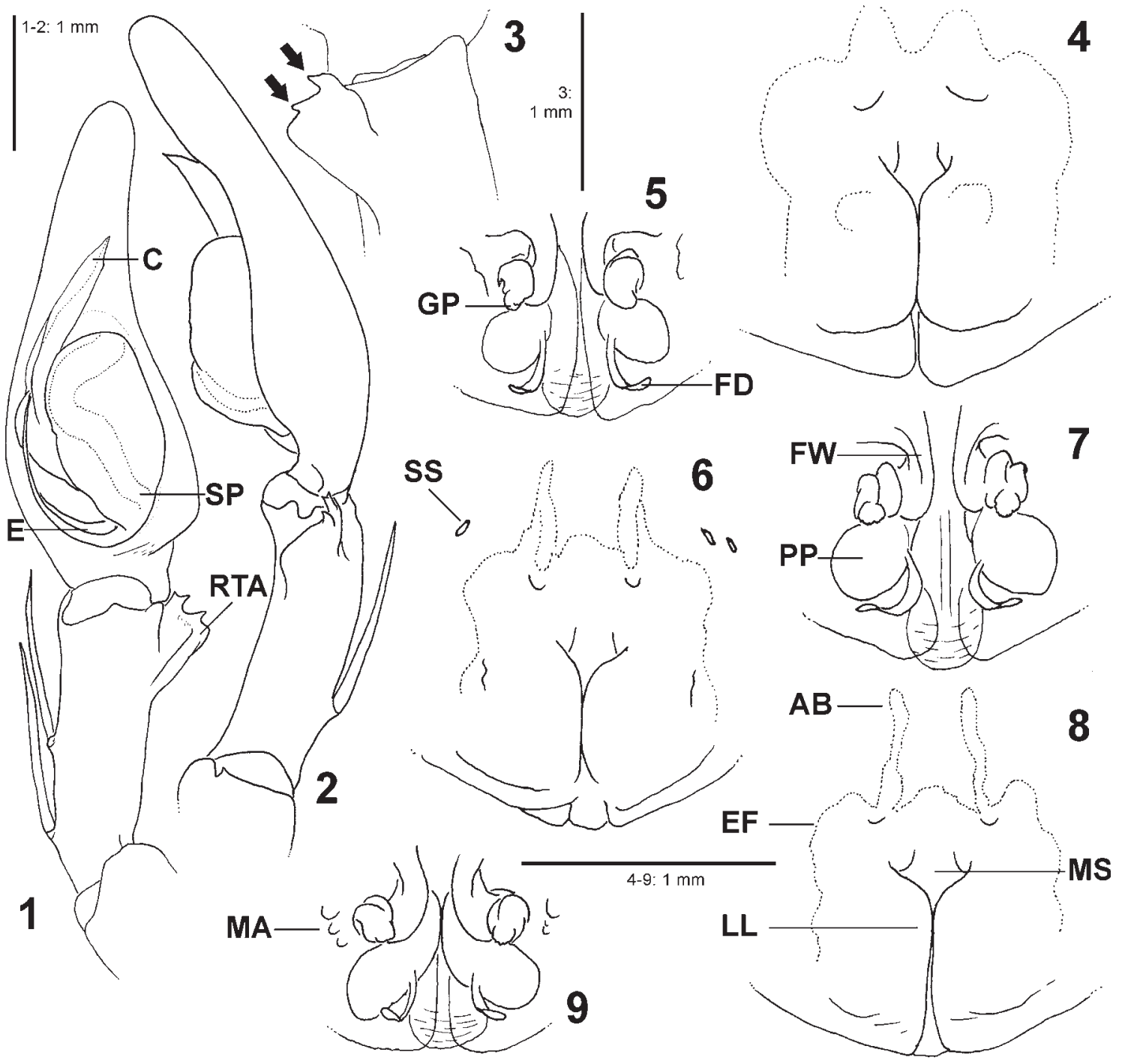

Figs 1-9. Heteropoda venatoria from Vietnam (1-2) and Krakatau (3-9), copulatory organs of males (1-3) and females (4-9). 1-2 left male palp (1 - ventral, 2 - retrolateral); 3 - RTA, dorsal; 4, 6, 8 - epigyne, ventral; 5, 7, 9 - internal duct system, dorsal. AB anterior bands, $\mathrm{C}$ - conductor, $\mathrm{E}$ - embolus, $\mathrm{EF}$ - epigynal field, FD — fertilization duct, FW — first winding of internal duct system, GP - glandular parts, LL — lateral lobes, MA - muscle attachment point, MS - median septum, PP - posterior part of internal duct system, RTA - retrolateral tibial apopyhsis, SP — spermophor, SS - slit sensilla. Arrows pointing to teeth-shaped extensions on dRTA.

Рис. 1-9. Heteropoda venatoria из Вьетнама (1-2) и Кракатау (3-9), копулятивные органы самцов (1-3) и самок (4-9). 1-2 левая пальпа самца (1 - вентрально, 2 - ретролатерально); 3 - RTA, сверху; 4, 6, 8 - эпигина, вентрально; 5, 7, 9 внутренняя система каналов сверху. АВ - передние полосы, С - кондуктор, Е - эмболюс, EF - область эпигины, FD оплодотворительный каналец, FW - первый изгиб семяпровода, GP - железистые участки, LL - боковые лопасти, MA мускульные точки, MS - септум, PP — задняя часть эндогины, RTA — ретролатеральный отросток голени, SP — cпермофор, SS щелевидный орган. Стрелки указывают на зубчатый вырост dRTA.

NOTE. Biswas \& Raychaudhuri, 2005: 104, figs $1-$ 7 ( $\bigcirc^{7}$, sub H. venatoria; misidentification). The species illustrated is definitely not $H$. venatoria. From none of the illustrations a statement can be made about the identity of this species.

For complete references and synonymies for $H$. venatoria see Platnick (2013).

ADDITIONAL MATERIAL EXAMINED: India: 3 우 (PJ 383-385), N India, Kooloo [= Kullu; 31 $57^{\prime} 37.09^{\prime \prime} \mathrm{N}, 77^{\circ} 6^{\prime} 31.12^{\prime \prime} \mathrm{E}$, $1200 \mathrm{~m}$, M.M. Carleton, 1870? (MCZ). $10^{7}$ (PJ 3), SE West Bengal, Kanchrapara $\left[22^{\circ} 56^{\prime} 2.01^{\prime \prime} \mathrm{N}, 8^{\circ} 25^{\prime} 50.88^{\prime \prime} \mathrm{E}, 15 \mathrm{~m}\right]$, Mont

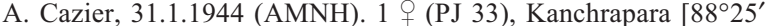
$\left.50.88^{\prime \prime} \mathrm{E}, 88^{\circ} 25^{\prime} 50.88^{\prime \prime} \mathrm{E}, 15 \mathrm{~m}\right], 1 .-30.6 .1944$ (AMNH). 1 우 (PJ $502)$, Calcutta $\left[22^{\circ} 34^{\prime} 9.06^{\prime \prime} \mathrm{N}, 88^{\circ} 21^{\prime} 43.53^{\prime \prime} \mathrm{E}, 12 \mathrm{~m}\right]$, Gravely, (NHMW). Nepal: $1 \sigma^{7}$ (PJ 194, 196), Tainkot, Hubert, 6.5.1990

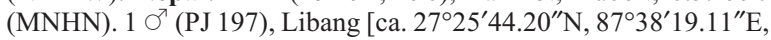
2100 m], Hubert, 4.+6.5.1990 (MNHN). 1 + , Kathmandu District, Kathmandu-Baneshwar $\left[27^{\circ} 43^{\prime} \mathrm{N}, 85^{\circ} 19^{\prime} \mathrm{E}\right], 1350 \mathrm{~m}$, J. Martens \& W. Schawaller, 18.4.1995 (SMF). 1 \%, Mugli [close to Baglung; $28^{\circ} 16^{\prime} \mathrm{N}, 83^{\circ} 36^{\prime} \mathrm{E}$ ], $250 \mathrm{~m}$, J. Martens, 1.6.1995 (SMF). 1 \% , Kathmandu-Balaju $\left[27^{\circ} 43^{\prime} \mathrm{N} 85^{\circ} 19^{\prime} \mathrm{E}, 1350 \mathrm{~m}\right]$, J. Martens, 26.3.1973 (SMF). 1 + (PJ 3196), Trisuli valley, $800 \mathrm{~m}\left[28^{\circ} 01^{\prime} \mathrm{N}, 85^{\circ} 11^{\prime} \mathrm{E}\right]$, J. Martens, 23.4.2004, SD 14 (SMF). Bhutan: $10^{\top}$ (PJ 217), border of Teesta valley [Sikkim?] (MCZ). Sri Lanka: $2 O^{7} \sigma^{7}$ (PJ 510- 

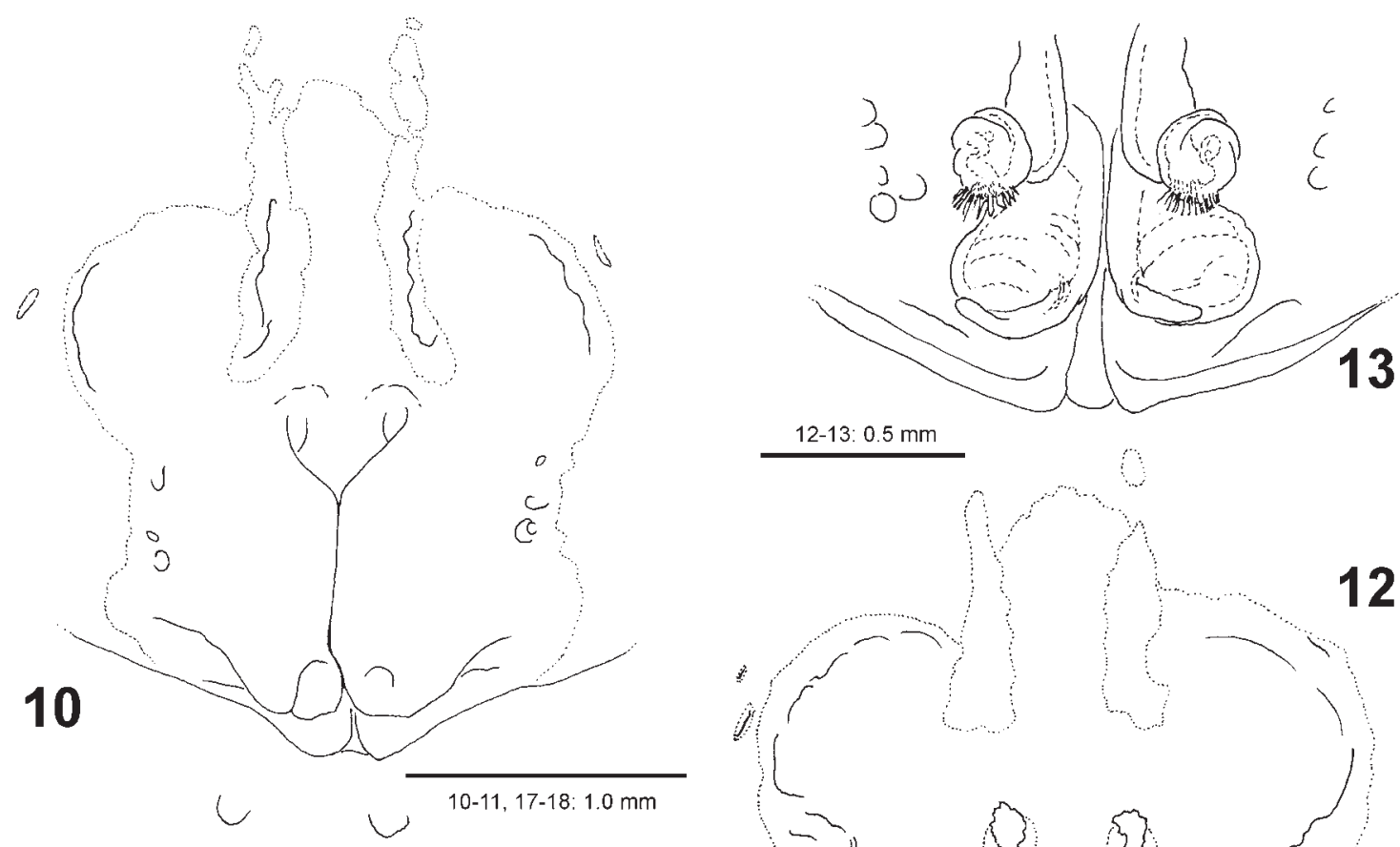

13
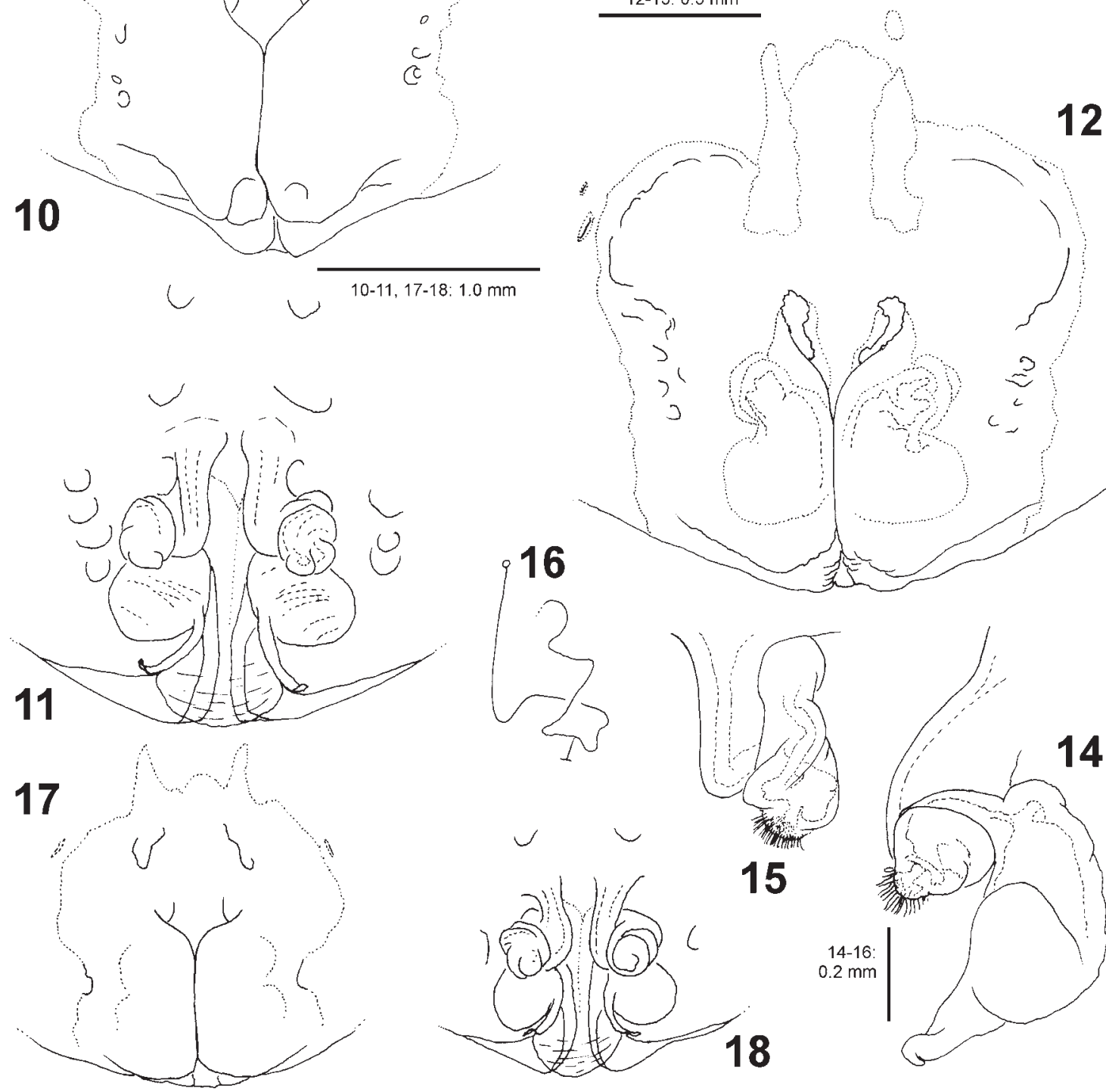

Figs 10-18. Heteropoda venatoria from Vietnam (10-11), Hainan (12-16) and Singapore (17-18), copulatory organs of females. 10, 12, 17 - epigyne, ventral; 11, 13-16, 18 - internal duct system $(11,13,18$ - dorsal; 14 - lateral; 15-16 - frontal).

Рис. 10-18. Heteropoda venatoria из Вьетнама (10-11), Хайнань (12-16) и Сингапура (17-18), копулятивные органы самок. $10,12,17$ - эпигина, вентрально; 11, 13-16, 18 - вульва (11, 13, 18 - сверху; 14 - латерально; 15-16 - спереди).

511), 4 우 (PJ 512-515), Redemann, 1893 (NHMW). 1 ○ (PJ 540), 7 우 (PJ 541-547), Locbell, 1899 (NHMW). 1 ○ (PJ 109), Kandy, Lady Horton's drive $\left[7^{\circ} 18^{\prime} 1.37^{\prime \prime} \mathrm{N}, 80^{\circ} 38^{\prime} 35.56^{\prime \prime} \mathrm{E}, 620\right.$ m], J. Mastbaum, 13.2.1914, S.G. IV 1914 (SMF). 1 ㅇ (PJ 48),
Ceylon (SMF 6086). 2 qo (PJ 49-50), Ceylon: Nunvura? (SMF 5559). Bangladesh: $1 \sigma^{7}$ (PJ 394), Chittagong, hill tracts: Rangamati $\left[22^{\circ} 39^{\prime} 26.33^{\prime \prime} \mathrm{N}, 92^{\circ} 10^{\prime} 25.27^{\prime \prime} \mathrm{E}, 48 \mathrm{~m}\right.$ altidtude], R. Paynter, 21.-27.2.1958 (MCZ). 1 ○ (PJ 395), E Pakistan [=Banglade- 


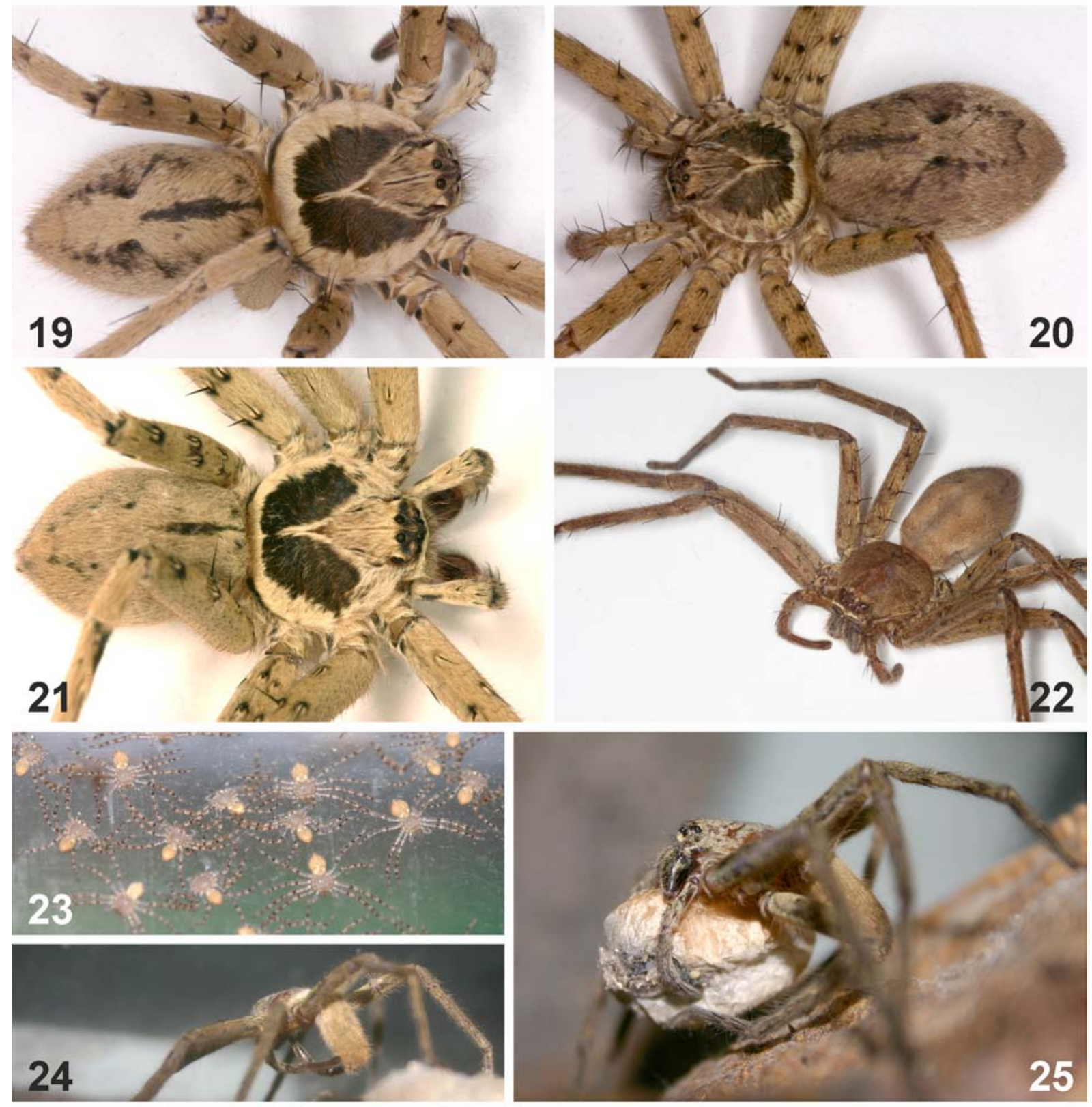

Figs 19-25. Heteropoda venatoria from Mauritius (19-20), Philippines (21), Dominican Republic (22) and Sri Lanka (23-25), habitus of males $(19,21)$, subadult male $(20)$, juveniles (23 showing distinctly different leg colouration than adults) and females $(22,24$ 25 showing cleaning and egg-sac carrying behaviour with hatching offspring).

Рис. 19-25. Heteropoda venatoria из Маврикия (19-20), Филиппин (21), Доминиканской Республики (22) и Шри Ланки (23$25)$, габитус самцов $(19,21)$, субадультный самец $(20)$, ювенилы (23 - показана окраска ног существенно отличющаяся от взрослых) и самок $(22,24-25$ - показаны чистка, перенос кокона с вылупляющейся молодью).

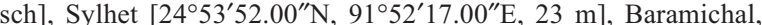
R. Paynter Jr., 26.4.-10.5.1958 (MCZ). Burma: $10^{7}$ (PJ 310), Karen Hills, Asciuii Cheba, Ghecu [ca. $19^{\circ} 19^{\prime} 31.89^{\prime \prime} \mathrm{N}, 96^{\circ} 48^{\prime}$ $2.99^{\prime \prime}$ E, 1100 m] (MCSN). 3 우 (PJ 396-398), Pegu [=Bago; $17^{\circ}$ $\left.19^{\prime} 60.00^{\prime \prime} \mathrm{N}, 96^{\circ} 28^{\prime} 60.00^{\prime \prime} \mathrm{E}, 15 \mathrm{~m}\right]$, C. H. Carpenter, 11.1966

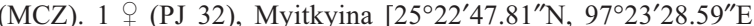
145 m], Capt. D.N. Marks (AMNH). 1 क (PJ 72), Mt. Victoria [21 $1^{\circ} 13^{\prime} 12.61^{\prime \prime} \mathrm{N}, 93^{\circ} 55^{\prime} 0.71^{\prime \prime} \mathrm{E}$, ca $2400 \mathrm{~m}$ ] (SMF 7961). China: 1 $\sigma^{\prime}$ (PJ 3358), Yunnan, Gaoligong Shan, 22 $54.439^{\prime} \mathrm{N}, 106^{\circ} 29$. $147^{\prime} \mathrm{E}, 1600 \mathrm{~m}$, J. Martens, 4.6.2011, by hand (SMF 62118). 4 우우 (PJ 503-505, 569), Shanghai $\left[31^{\circ} 16^{\prime} 8.40^{\prime \prime} \mathrm{N}, 121^{\circ} 29^{\prime} 22.56^{\prime \prime} \mathrm{E}, 10\right.$ $\mathrm{m}]$, Celebor, 18.1.1856, 15. 8.1896 (NHMW). (NHMW). 7 오오 (PJ $602-608)$, Hongkong $\left[22^{\circ} 18^{\prime} 39.28^{\prime \prime} \mathrm{N}, 114^{\circ} 10^{\prime} 38.53^{\prime \prime} \mathrm{E}, 30 \mathrm{~m}\right]$,
Berg, 1899, 019. (NHMW). 3 오 (PJ 2876-2878), Hainan, Mt. Bawangling, $19.1^{\circ} \mathrm{N}, 109.1^{\circ} \mathrm{E}$ (IZCAS). Taiwan: 1 ㅇ (PJ 1324), Kuantzuling, R. Kano[?], 25.5.1992 (NSMT-Ar 4202). 3 O $^{7} \sigma^{7}, 2$ 우, Pingtung County, Kengting, close to Howard Beach resort, $21^{\circ} 56.294^{\prime} \mathrm{N}, 120^{\circ} 48.531^{\prime} \mathrm{E}, 24 \mathrm{~m}$, secondary forest, S. Huber \& D. Court, 26-28.6.2013 (SMF 64113-64117). Japan: $10^{7}$ (PJ

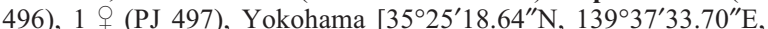
$40 \mathrm{~m}]$ (NHMW). 1 ㅇ (PJ 461), Nagasaki [32 $45^{\prime} 1.03^{\prime \prime} \mathrm{N}, 129^{\circ}$ 52'39.60"E, $20 \mathrm{~m}$ ], 14.6.1886, sub H. invicta (NHMW). 1 옹 (PJ 40), Kochi Province, Inoskiri, in institute, 10.197(1)9? (SMF). 1 ㅇ (PJ 1305), 1940 (NSMT-Ar 4206). 1 O $^{7}$ (PJ 469), A.-N. 1879.II.20., Arachn. Inv.No. 17.863, sub Sarotes invictus (NHMW). $10^{7}$, Tokyo, Chichijima, Ogasawara Islands $\left[27^{\circ} 4^{\prime} 36.87^{\prime \prime} \mathrm{N}, 142^{\circ}\right.$ 


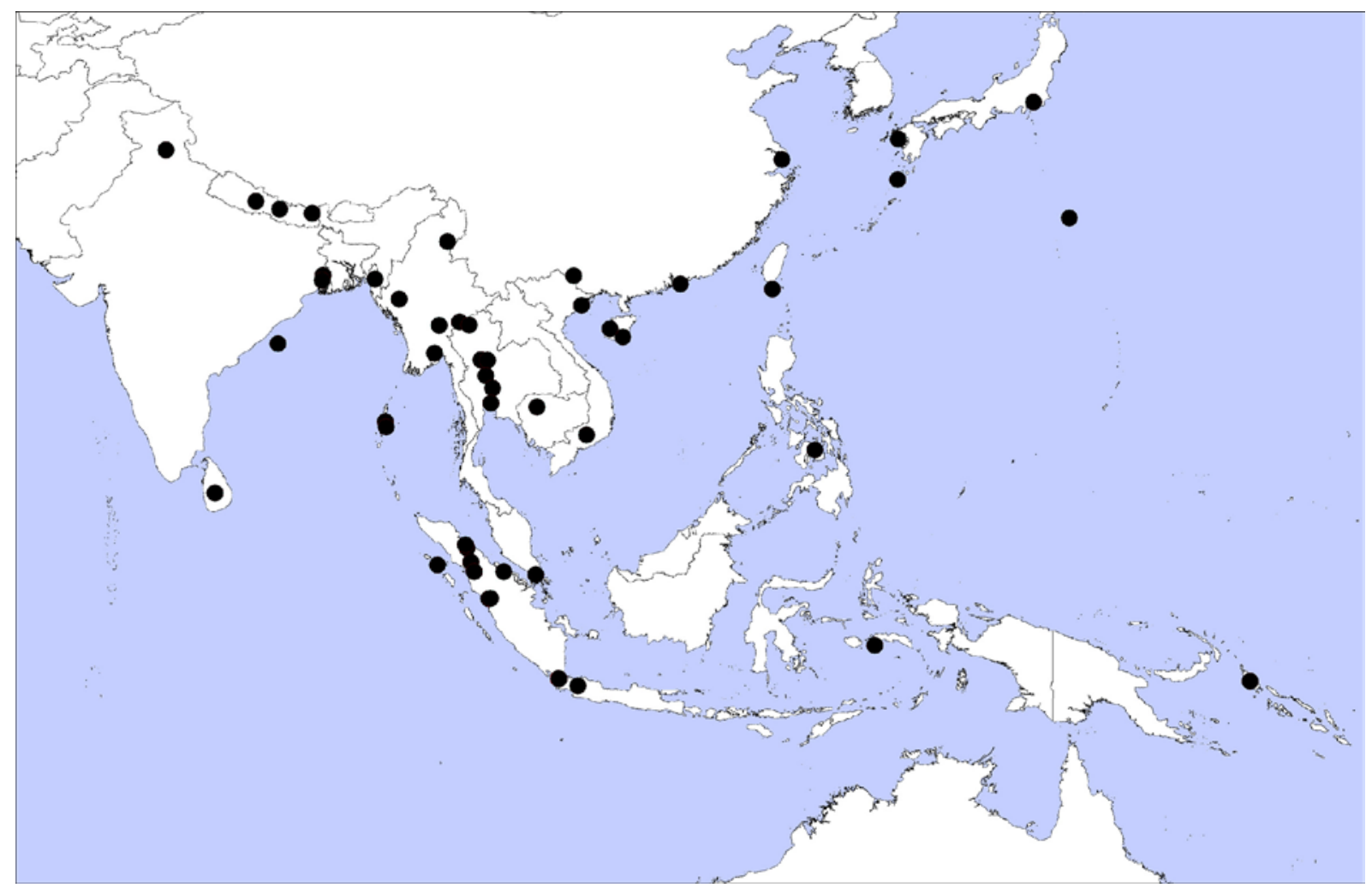

Fig. 26. Map of distributional records of Heteropoda venatoria in South, East and Southeast Asia. The records represent only a small fraction of the real distributional account, since this species is a pantropical spider occurring in almost every habitat in the tropics. Interesting to note where the northern boundary of the natural distribution (not in-house records) may be located.

Fig. 26. Карта с находками Heteropoda venatoria в южной, восточной и юго-восточной Азии. Точки показывают только небольшую часть находок, поскольку этот пантропический вид встречается практически в каждом биотопе в тропиках.

$12^{\prime} 51.00^{\prime \prime} \mathrm{E}, 160 \mathrm{~m}$ ], H. Ono, 20.5.2010 (SMF 63750). Thailand: $1 \mathrm{O}^{7}$, Mae Hong Son Province, near Soppong [19³4'28.36" N, $\left.98^{\circ} 16^{\prime} 45.54^{\prime \prime} \mathrm{E}, 660 \mathrm{~m}\right]$, bamboo internodes filled with water, Kovac, 8.2002 (SMF 63751). 1 (PJ 377), Chiang Dao [19 $\left.21^{\prime} 58.91^{\prime \prime} \mathrm{N}, 98^{\circ} 57^{\prime} 59.91^{\prime \prime} \mathrm{E}\right], 400 \mathrm{~m}, 10.12 .1986$, Coll. Raven (QMS 28044). $1 \sigma^{\top}$, Sukothai, Khiri-Mat (=Ban Tanot) $\left[16^{\circ} 50.026^{\prime} \mathrm{N}\right.$ 9947.996' E], 60 m, W. Thielen, VI.1986 (SMF 63612). 2 우, Phitsanulok $\left[16^{\circ} 49.443^{\prime} \mathrm{N}, 100^{\circ} 15.983^{\prime} \mathrm{E}\right], 60 \mathrm{~m}, \mathrm{~W}$. Thielen, VI.1986 (SMF 63618). $10^{7}, 2$ 90, Nakhon Sawan Province, 3 km W Ban Taling Sung [15 $\left.52.367^{\prime} \mathrm{N}, 99^{\circ} 21.208^{\prime} \mathrm{E}\right], 140 \mathrm{~m}$, W Thielen, 1987 (SMF 63613). 1 , Nakhon Sawan Province, 5 km E Nakhon Sawan Town $\left[15^{\circ} 42.259^{\prime} \mathrm{N}, 100^{\circ} 9.449^{\prime} \mathrm{E}\right], 90 \mathrm{~m}, \mathrm{~W}$ Thielen, 6.1986 (SMF 63615). $2 \sigma^{\top} \sigma^{\top}$ (PJ 324-325), Lop Buri [14 $\left.48^{\prime} 9.65^{\prime \prime} \mathrm{N}, 100^{\circ} 39^{\prime} 2.45^{\prime \prime} \mathrm{E}, 20 \mathrm{~m}\right]$, ca. $100 \mathrm{~km} \mathrm{~N}$ of Bangkok, on walls in an old house of store, Remy Van Herck, 13.4.1993,

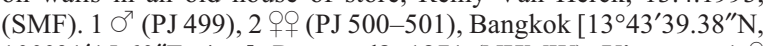
$100^{\circ} 31^{\prime} 15.60^{\prime \prime} \mathrm{E}, 4 \mathrm{~m}$ ], Rausonel?, 1871 (NHMW). Vietnam: 1 (PJ 1164), Ky Thuong, roof of village chief, by night, 05.7.1997, Coll. Ziegler (SMF). $1 \sigma^{\top}$ (PJ 409), 1 ( (PJ 410), Nam Cat Tien, $11^{\circ} 26^{\prime} \mathrm{N}, 107^{\circ} 26^{\prime} \mathrm{E}, 200 \mathrm{~m}$, Malicky, 17.-25.6.1995 (SMF 63753) 1 古 (PJ 285), N Vietnam, Cat Ba island $\left[20^{\circ} 47^{\prime} 2.31^{\prime \prime} \mathrm{N}, 107^{\circ}\right.$ $\left.3^{\prime} 55.17^{\prime \prime} \mathrm{E}, 10 \mathrm{~m}\right]$, near Haifon, in house, V.V. Yanushev, 11.12.1.1989 (ZMUM). 1 (PJ 1160), NW Ky Thuong, river Bau Tay, T. Ziegler, 07.7.2997 (SMF). 1 \% (PJ 280-281), with 187 nymphs, S Vietnam, Koshinin, in a hotel, A. Tykulov \& M.Y. Kalyakin, 28.7.1989 (ZMUM). 1 \& (PJ 284), Koshinin, A.A. Kuznetsov 12.4.1994, Acq.No. 4-1995 (ZMUM). 1 (PJ 282), Dong Nai Province, Ma Da, in a hotel, M.V. Kalyakin, 9.6.1999 (ZMUM) 2 우 (PJ 1170-1171), Vuih, Ziegler, 19.8.1997 (SMF). 1 ○ (PJ 275), N Vietnam, Haifon, 1960 (ZMUM). 1 ○ (PJ 277), Thuan Hai Province, Qua Phu, near S border of Phan Tui, palm, in a hole, V.V. Yanushev, 31.3.1987 (ZMUM). 1 क (PJ 278), S Vietnam,
Daklak Province, ca. $40 \mathrm{~km}$ NW of Buon Ma Thuot, Buon Ya Wan, 450 m, L. Medvedev et al., 2.-3.5.1986 (ZMUM). 1 (PJ 279), S Vietnam, Dong Nai Province, Ma Da forest, M.Y. Kalyakin, 1990, Acq.No. 32-1992 (ZMUM). 1 ○ (PJ 283), S Vietnam, Dong Nai Province, Ma Da, in house, M.V. Kalyakin, 23.8.1989, Acq.No. 11990 (ZMUM). Cambodia: $1 \sigma^{\top}$ (PJ 3414), Siem Reap, Angkor Thom area, $13^{\circ} 26.517^{\prime} \mathrm{N}, 103^{\circ} 51.358^{\prime} \mathrm{E}$ [40 m], S. Huber, 28.11. 2012 (SMF 63663). Malaysia: 1 क (PJ 465), Borneo, Sarawak (NHMW). Singapore: $1 O^{7}$ (PJ 495), Novara-travel (NHMW). 1 ㅇ (PJ 1720), Kranji War Memorial $\left[1^{\circ} 25^{\prime} 9.50^{\prime \prime} \mathrm{N}, 103^{\circ} 45^{\prime} 29.92^{\prime \prime} \mathrm{E}\right.$, $35 \mathrm{~m}]$, S. Huber, 24.12.2000 (SMF). Indonesia: 1 q (PJ 498), Medan [3 $3^{\circ} 35^{\prime} 10.24^{\prime \prime} \mathrm{N}, 98^{\circ} 40^{\prime} 33.63^{\prime \prime}$ E, 26 m], S.O.K., L. Fulmek (NHMW). 2 우 (PJ 1320-1321), Domai [=Dumai; 1 ${ }^{\circ} 37^{\prime} 55.67^{\prime \prime} \mathrm{N}$, $101^{\circ} 26^{\prime} 28.10^{\prime \prime} \mathrm{E}, 2 \mathrm{~m}$ ], jungle, 24.7.1971 (NSMT-Ar 4199). 4 우

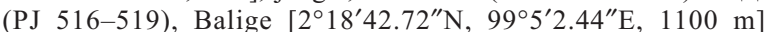

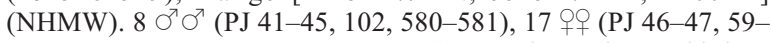
61, 103-104, 110, 133-134, 582-588), Fort de Kock [=Bukittinggi; $0^{\circ} 18^{\prime} 51.93^{\prime \prime} \mathrm{S}, 100^{\circ} 22^{\prime} 25.24^{\prime \prime} \mathrm{E}, 930 \mathrm{~m}$ ], E. Jacobson, 11.1913

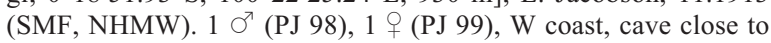
Baso [0¹7'11.25"S, 100³0'2.02"E, $860 \mathrm{~m}$ ], E. Jacobson, 10.1913 (SMF 4591). 2 우 (PJ 51-52), Sumatra, Simalur, Pulu Babi, $2^{\circ} 7^{\prime} \mathrm{N}$,

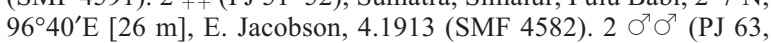
75), 5 우 (PJ 65-67, 76-77), W Sumatra, Bungar-Bondar [1 $\left.{ }^{\circ} 38^{\prime} 31.00^{\prime \prime} \mathrm{N}, 99^{\circ} 19^{\prime} 32.50^{\prime \prime} \mathrm{E}, 1140 \mathrm{~m}\right]$, Schultz ,14.4.1914 (SMF). $1 \sigma^{\top}$ (PJ 412-413), 1 9 (PJ 411), Krakatau Island, Sertung, forest, $6^{\circ} 05^{\prime} \mathrm{S}, 105^{\circ} 23^{\prime} \mathrm{E}$ [72 m], 11.9.1984 (NMBE). 1 ㅇ (PJ 414), Krakatau, Anak [6 $\left.6^{\circ} 5^{\prime} 52.25^{\prime \prime} \mathrm{S}, 105^{\circ} 25^{\prime} 44.02^{\prime \prime} \mathrm{E}, 34 \mathrm{~m}\right], 9.1990$, (NMBE). $10^{7}$ (PJ 487), 3 오 (PJ 488-490), Java, 14.2.1882 (NHMW). 2 $\sigma^{7} \sigma^{\top}$ (PJ 527-528), 3 우 (PJ 529-531), Java, Buitenzorg [6 $6^{\circ} 36^{\prime}$ $0.00^{\prime \prime} \mathrm{S}, 106^{\circ} 48^{\prime} 0.00^{\prime \prime} \mathrm{E}, 260 \mathrm{~m}$ ], Jacobson (NHMW). $2 \mathrm{O}^{7} \mathrm{O}^{7}$ (PJ 570-571), 7 우 (PJ 572-578), Java (NHMW). $1 \sigma^{77}$ (PJ 520), 6 우 (PJ 521-526), Borneo, Ida Pfeiffer, 10.2.1853 (NHMW). $1 \overbrace{}^{7}$ (PJ 
532), 7 우 (PJ 533-539), Borneo, Tervek, Breitenstein, 26.3.1882 (NHMW). 2 우 (PJ 506-507), Sulawesi, Wolf, 1893 (NHMW). 2

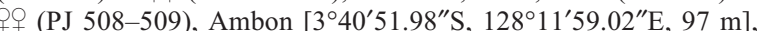
Doleschall, 32.I.1858 (NHMW). 1 ㅇ (PJ 601), Ambon, 7.1922 (NHMW). 1 ○ (PJ 1167), 1 ๆ (PJ 1168), Moluccas, Seram, 1996 (SMF). Philippines: $6 \sigma^{T} \sigma^{T}$ (PJ 548-553), 5 우 (PJ 554-558), Schadenberg, 1890 (NHMW). $1 \sigma^{7}$ (PJ 2851), Cebu City, Busay $\left[10^{\circ} 21^{\prime} 45.34^{\prime \prime} \mathrm{N}, 1^{\circ} 52^{\circ} 52.67^{\prime \prime} \mathrm{E}, 300 \mathrm{~m}\right]$, S. Huber, 13.3.2008 (SMF 63752). Papua New Guinea: $1 \sigma^{7}$ (PJ 1364), 3 오 (PJ 90 92), Bougainville, E coast, village Tobvoor? [Toboroi; $6^{\circ} 16^{\prime} 15.65^{\prime \prime} \mathrm{S}$

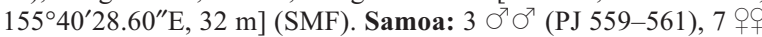

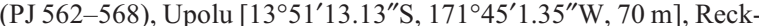
ingen (NHMW). Without clear locality: 2 우 (PJ 597-598), South Seas, Islands, 14.2.1882, Godeffroy, 1890 (NHMW). $1 \sigma^{7}$ (PJ 276), N.A. Zarenkov (ZMUM). 1 (PJ 111), [likely S India or Sri Lanka] R. Moll, 6.1913 (SMF).

More material was treated in Jäger [2000, 2002, 2007], Jäger \& Ono [2000; also sub H. tokarensis], Jäger \& Yin [2001], Jäger \& Kunz [2005] and Jäger \& Praxaysombath [2009]. Additional extensive unpublished material was examined and identified as $H$. venatoria from numerous museum collections (e.g., MNHN, Zoologische Staatssammlung Munich, Zoological Museum of the University Copenhagen).

NOTES ON SYNONYMIES. From the illustration of C.L. Koch [1845: fig. 982] his Ocypete thoracica is clearly $H$. venatoria with the typical dorsal pattern of prosoma. Thorell [1878: 192] did not describe the female as listed in Platnick [2013], but mentioned only a dubious juvenile specimen from a cave in Ambon: "exemplum singulum adultum (masculum) vidi. Femina adulta mihi ignota est" [I have seen a single adult male specimen. An adult female is unknown to me]. Platnick [2013] refers to page 23 in Koch's book, but there is no mention of this species, but on three different pages as indicated in the index (pp. 192, 273, 306). Thorell [1878: 193] mentioned the similarity with $H$. venatoria. Merian [1911] interpreted the form as subspecies ("Varietät") of $H$. venatoria.

L. Koch [1878] described two females as two new Sarotes species. One of them, Sarotes aulicus, is clearly identifiable as $H$. venatoria from the illustration (fig. 31 ), considering that only one other true Heteropoda species is occurring in Japan, $H$. simplex. This latter species shows a distinct different epigyne with its median septum freely visible and lateral lobes distinctly separated. The second species, Sarotes invictus, is not easy to identify from the illustration (fig. 32) and it was misidentified by Bösenberg \& Strand [1906: 275, fig. 448]. The latter authors illustrated a male which belongs clearly to Sinopoda forcipata (Karsch, 1881). The female holotype (see also Nishikawa \& Sattmann [2001] and their comments on the Roretz collection), however, belongs clearly to $H$. venatoria, therefore there is no doubt about this synonymy.

The female holotype of Sarotes peditatus Karsch, 1881 is clearly a $H$. venatoria, therefore a synonym of it. The holotype female has a body length of $27.3 \mathrm{~mm}$, Karsch [1881] wrote in his original description "ca. 30 mm". Considering, that ethanol specimens have a longer petiolus than in the condition when specimens were alive the size given by Karsch may be explained by this fact.
McCook [1878] noted in his description of Sarotes truncus, that only the shape of the prosoma differed from other specimens of $H$. venatoria "that it is probably entitled to be classified as a new species". This sentence together with the question mark behind ("Sarotes truncus, n. sp.?") and the annotation "the eyes and other parts correspond generally with those of $S$. venatorius" makes it most likely that the prosoma was damaged during the final moult and caused this misidentification.

Strand [1907] described three variations of $H$. venatoria: japonica, chinesica, maculipes. The first two forms clearly belong to $H$. venatoria, as Strand [1907, 1909] describes the typical shape of the male RTA. According to my observations on this species in the past 13 years the two teeth at the distal margin of the dRTA may vary in size and shape. None of these variations proved to be a diagnostic character of an own species. The same is valid to a certain extend for variation of female epigynes. In $H$. v. maculipes Strand stresses a colour variation. Since he lists in 1909 more material of this form from various regions including one caught "an Bord" (on board), it is most likely that $H$. venatoria is concerned considering that this species is known as a globetrotter and is still dispersed with cargo via shipping.

Strand [1915] described a new species and a new variation: $H$. nicki from E Java and $H$. nicki quala from Sumatra. Both forms show structures of epigyne and vulva typical for $H$. venatoria. Since Strand gives no differential diagnosis for the new species, I can only suppose that the smaller size may be one reason to establish a new species. Similarly small specimens of $H$. venatoria are known from other localities, e.g., Krakatau (Figs 3-9). From the latter island several specimens including males could be examined and identified as $H$. venatoria. The same is also valid for $H$. tokarensis described by Yaginuma [1961]. Original illustrations of male and female copulatory organs show clearly conspecifity with $H$. venatoria.

Tikader [1977] described H. andamanensis from Andaman Islands. Although some features in the original illustrations point to species status of the described specimens (e.g. hook-shaped dRTA, extremely narrow anterior width, median septum slightly visible), Sethi \& Tikader [1988] revise some of these structure with their drawings of the same specimens: anterior width of the prosoma is now wider, dRTA is prominent, but not hook-shaped, and lateral lobes of female epigyne touching each other. Therefore and from other features similar to those in $H$. venatoria (e.g., course of male spermophor, course and shape of internal duct system, as far as recognisable from fig. 45 of Sethi \& Tikader [1988]) conspecifity with $H$. venatoria is most likely.

Heteropoda nicobarensis was described by Tikader [1977] from the Nicobar Islands, Sethi \& Tikader [1988] illustrated the female holotype and showed the vulva for the first time. All illustrations and especially the type locality ("guest house") point to conspecifity with $H$. venatoria, which is known as widespread species invading human buildings. 
Illustrations of Li [1991] for H. hainanensis identify this species clearly as synonym of $H$. venatoria. Additional evidence give the three female specimens from Hainan, Mount Bawangling listed in the material section above, the type locality of $H$. hainanensis.

DIAGNOSIS. Males are distinguished from all other Heteropoda species by the two teeth-like projection on the dRTA (Fig. 3: arrows). Additional character in combination is the course of the spermophor with a large bend at a right angle in distal half of tegulum. Females do not exhibit a unique character like males. Probably they are best compared in a differential diagnosis with $H$. tetrica (cf. Eusemann \& Jäger, 2009: fig. 2 ). Epigyne of both species usually with lateral lobes touching each other along the median line showing only very anterior and posterior part of median septum (Figs $4,6,8,10,12,17$ ) with $H$. tetrica showing a higher variation. Internal duct system of $H$. venatoria with first windings almost parallel (distinctly bent in $H$. tetrica) and narrow glandular parts situated posterolaterally to first winding (Figs 5, 7, 9, 11, 13, 18) (wide glandular parts situated usually posteriorly to posterior-medially in $H$. tetrica). Sexual colour dimorphism (Figs 19-22) and especially the distinct colouration of the male with the bilobate dark patch on the dorsal shield of prosoma may help identify specimens from outside Asia and Australia, i.e. from the Americas, from Africa as well as from Europe. When localities getting closer to north-western Southeast Asia more species with similar colour patterns in males are present (e.g., H. tetrica, compare Eusemann \& Jäger [2009: fig. 3]). Heteropoda tetrica males exhibit additionally to the bilobate dark patch two dark parallel bars in fron of this patch (cf. Eusemann \& Jäger 2009: fig. 3). Moroever, the bilobate patch in $H$. tetrica is interspersed with light radial lines.

DISTRIBUTION. Pantropical, introduced in other regions with established populations in warm-houses (Fig. 26 for records from present paper).

\section{Heteropoda pekkai sp.n.}

Figs 27-32, 51-53, 57.

TYPE MATERIAL. BHUTAN: Holotype + (PJ 170), $52 \mathrm{~km}$ from Phuntsholling in direction Thimpu $\left[26^{\circ} 56^{\prime} 3.43^{\prime \prime} \mathrm{N}, 89^{\circ} 30^{\prime}\right.$ 57.32 "E, $1980 \mathrm{~m}$ ], Natural History Museum of Basel-Bhutan-Expedition, 30.6.1972 (NHMB). Paratypes: BHUTAN: 1 ㅇ (PJ 171), $87 \mathrm{~km}$ from Phuntsholling $\left[27^{\circ} 2^{\prime} 52.10^{\prime \prime} \mathrm{N}, 89^{\circ} 34^{\prime} 9.46^{\prime \prime} \mathrm{E}\right.$, $1700 \mathrm{~m}], 22.5 .1972,30$, Natural History Museum of Basel-Bhutan Expedition, 1972 (SMF). 2 우 (PJ 2346-2347), with same data as preceding specimen (NHMB).

NOTES. Baroni Urbani et al. (1973) described the habitats of one locality as following (translation from German text): “...87 km behind Phuntsholing on the road to Thimphu, $1700 \mathrm{~m}, 30.4$., 22.-23.5.1972 (few kilometres behind Mathur bridge). Upper limit of the evergreen montane forest. The unobstructed forest contains many oaks, which gives it a Mediterranean appearance. Unique fauna, which differs strongly from that of other zones. Here with still quite a lot of tropical elements. The fauna associated with wood (in any way) and moss (Symphyla, Mecistocephalidae) very rich. ..." The geographic coordinates given in the "type material"-paragraph were obtained by the map published in Baroni Urbani et al. (1973) and measuring road kilometres in Google-Earth in combination.

ETYMOLOGY. The species name is honouring the contribution of Pekka Lehtinen's oeuvre in the field of arachnology on the occasion of his $80^{\text {th }}$ anniversary on 5. April 2014; noun (name) in genitive case.

DIAGNOSIS. Females. Medium sized (body length: 18.8-20.3), may be recognised by the following combination of characters (Figs 27-32): 1. anterior part of median septum twice as long as triangular posterior part, 2. internal duct system with first part long and consisting of two loops oriented in a right angle to each other. Heteropoda phasma Simon, 1897 (described from the vicinity of Dehra Dun, Himalaya) with similar copulatory organ, but with shorter median septum, septum with curved lateral margins (almost parallel in $H$. pekkai sp.n.) and median lobes more distinctly separated. From general organisation of the internal duct system H. afghana Roewer, 1962 may belong to this group, too, but can be recognised by its first winding distinctly shorter than in $H$. pekkai sp.n. and section of turning point not visible in ventral view.

DESCRIPTION. Female (holotype). Prosoma length 7.5 , width 6.5 , anterior width 3.6 , opisthosoma length 11.5, width 7.4. Eyes: AME 0.32, ALE 0.57, PME 0.43, PLE 0.51, AME-AME 0.24, AME-ALE 0.06, PME-PME 0.33, PME-PLE 0.53, AME-PME 0.34, ALE-PLE 0.44, clypeus height at AME 0.57, at ALE 0.45 . Spination: palp: $131,101,2121,1014$; legs: femur I-II 323, III 333, IV 332; patella I-II 001, III 001/ 101, IV 101; tibia I-II 2026, III-IV 2126; metatarsus I-II 1014, III 2014, IV 3036. Metatarsus IV ventrally with many bristles along entire length. Leg formula: 2413. Measurements of palp and legs: palp 11.8 (3.4, $1.8,2.9,-, 3.7)$, leg I $31.2(8.5,3.8,8.5,7.8,2.6)$, leg II $34.9(9.7,3.9,10.0,8.6,2.7)$, leg III $28.9(8.3,3.4,8.0$, $6.9,2.3)$, leg IV $31.8(9.1,3.2,8.2,8.6,2.7)$. Cheliceral furrow with 100-120 denticles in basal, restricted patch. Promargin of chelicerae with 3 teeth, retromargin with 4 teeth. Palpal claw with 7 teeth.

Copulatory organ as in diagnosis (Figs 27-32). Epigynal field as long as wide with distinct anterior bands and two slit sensilla on each side. Median septum with bent anterior rims. Internal duct system with posterior part with humps, longitudinally oval (Figs 27-32).

Colouration (Figs 51-53): yellowish- to reddishbrown with dark hairs. Dorsal shield of prosoma with bright transversal crescent submarginally on posterior end. Prosoma and legs ventrally without pattern. Chelicerae darker reddish-brown with lateral brighter humps basally. Opisthosoma dorsally darker anteriorly and posteriorly, with white chevrons in posterior half. Opisthosoma ventrally with 4 longitudinal rows of tiny muscle sigilla, the outer ones as brighter lines.

Male. Unknown.

VARIATION. Palpal claw with 7 ( +1 small tooth) or 8 teeth. Spination: femur III 332/333, IV 331; patel- 


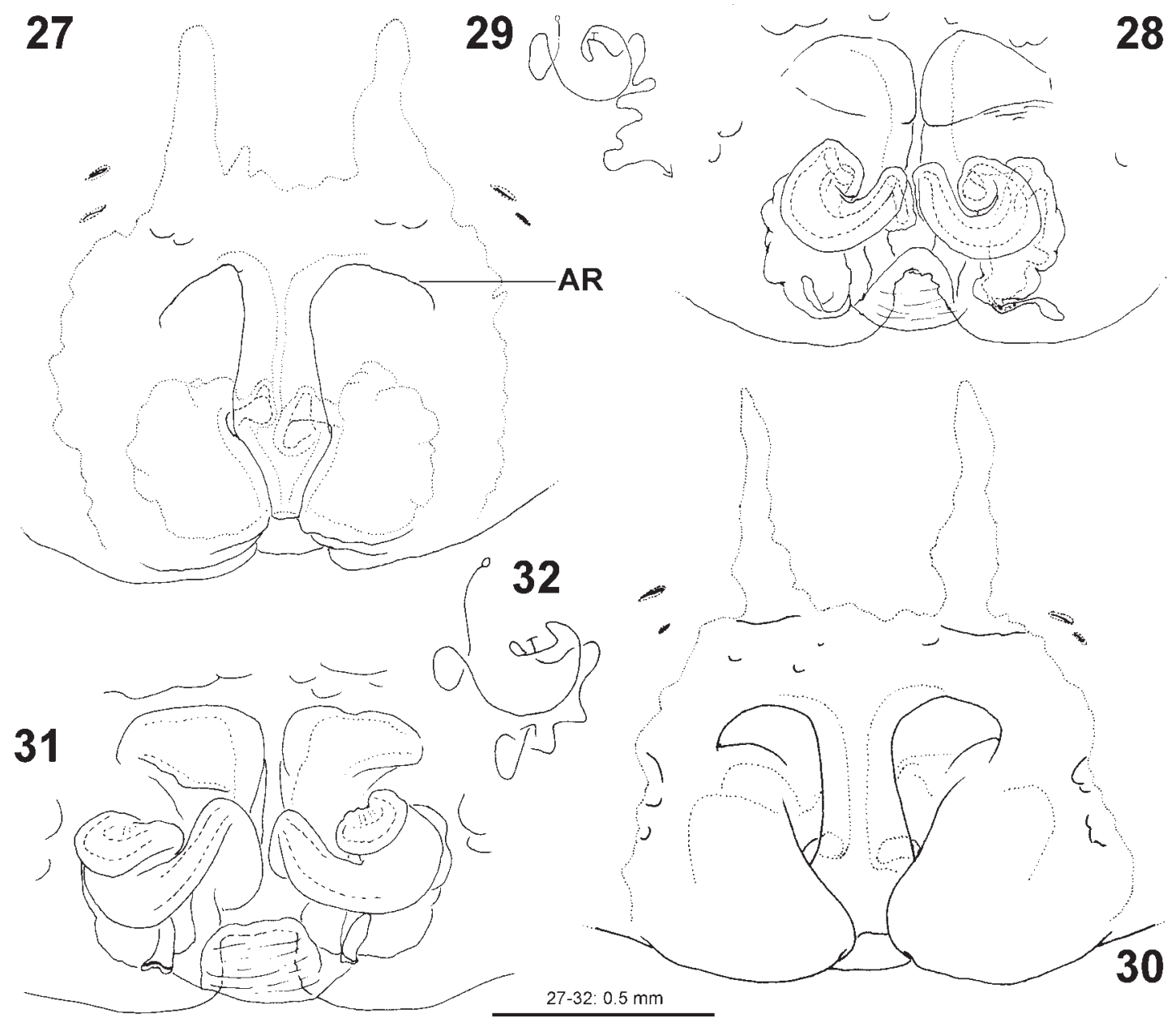

Figs 27-32. Heteropoda pekkai sp.n. from Bhutan, copulatory organ of holotype (27-29) and paratype (30-32). 27, 30 - epigyne, ventral; 28, 31 - internal duct system; 29, 32 - schematic course of internal duct system, dorsal. AR - anterior rims of median septum.

Рис. 27-32. Heteropoda pekkai sp.n. из Бутана, эпигина голотипа (27-29) и паратипа (30-32). 27, 30 - эпигина, вентрально; 28,31 - эндогина; 29,32 - схема канальцев эндогины, сверху. AR - передний край септума.

la I-IV 001, III 101 (left and right); tibia III 2026; metatarsus I 0014 , II 2026/1015, III 1016/2006 or 2026. Colouration in all paratypes darker, i.e. more reddish brown with dorsal shield of prosoma with radial markings, in one female spine patches slightly marked (PJ 2346), in general opisthosomal pattern more distinct especially dorsal chevrons. Epigyne of one female (PJ 2346) with more slender anterior bands, epigynal field slightly wider than long, general appearance of epigyne and vulva stouter.

DISTRIBUTION. Known from two localities in Bhutan (Fig. 57: cross).

RELATIONSHIPS. Cannot be assigned to any species group (but see remarks in diagnosis). It is characterised by the long copulatory ducts and their unique conformation: copulatory opening situated posteriorly where median septum meets lateral lobes. Anterior part of median septum acting seemingly as guiding groove for the embolus (Figs 27, 30). Copulatory ducts running dorsally and slightly anteriorly then turning later- ally (Figs 28, 31). In most Heteropoda species first winding is directed posteriorly and laterally.

\section{Heteropoda opo sp.n.}

Figs 33-50, 54-57.

TYPE MATERIAL. BURMA: Holotype 9 (PJ 3152), Kayin State, Hpa-An, Hai Sin Gu, $16^{\circ} 44^{\prime} 32.4^{\prime \prime} \mathrm{N}, 97^{\circ} 42^{\prime} 50.8^{\prime \prime} \mathrm{E}, 26 \mathrm{~m}$, in cave, H. Steiner, 29.1.2009, 011/09, NE 47-14-019, Myanmar Cave Documentation Project - European Cave Project (SMF). Paratypes: 1 (PJ 3151), with data as for holotype, except for: 008/ 09, SD 610 (SMF). 1 (PJ 3150), Kayin State, Hpa-An, Saddan Gu, $16^{\circ} 44^{\prime} 24^{\prime \prime} \mathrm{N}, 97^{\circ} 43^{\prime} 5.4^{\prime \prime} \mathrm{E}, 30 \mathrm{~m}$, in cave, H. Steiner, 29.1.2009, 007/09, NE 47-14-012, Myanmar Cave Documentation Project European Cave Project, SD 609 (SMF).

ETYMOLOGY. The species name is derived from the English term "OverPOpulation" stressing the negative impact of the human overpopulation on natural habitats and biological diversity; term in apposition.

DIAGNOSIS. Large to very large (body length of females: $31.9-42.5$, leg span leg II of female up to $220 \mathrm{~mm}$ ). Females similar to those of $H$. maxima 


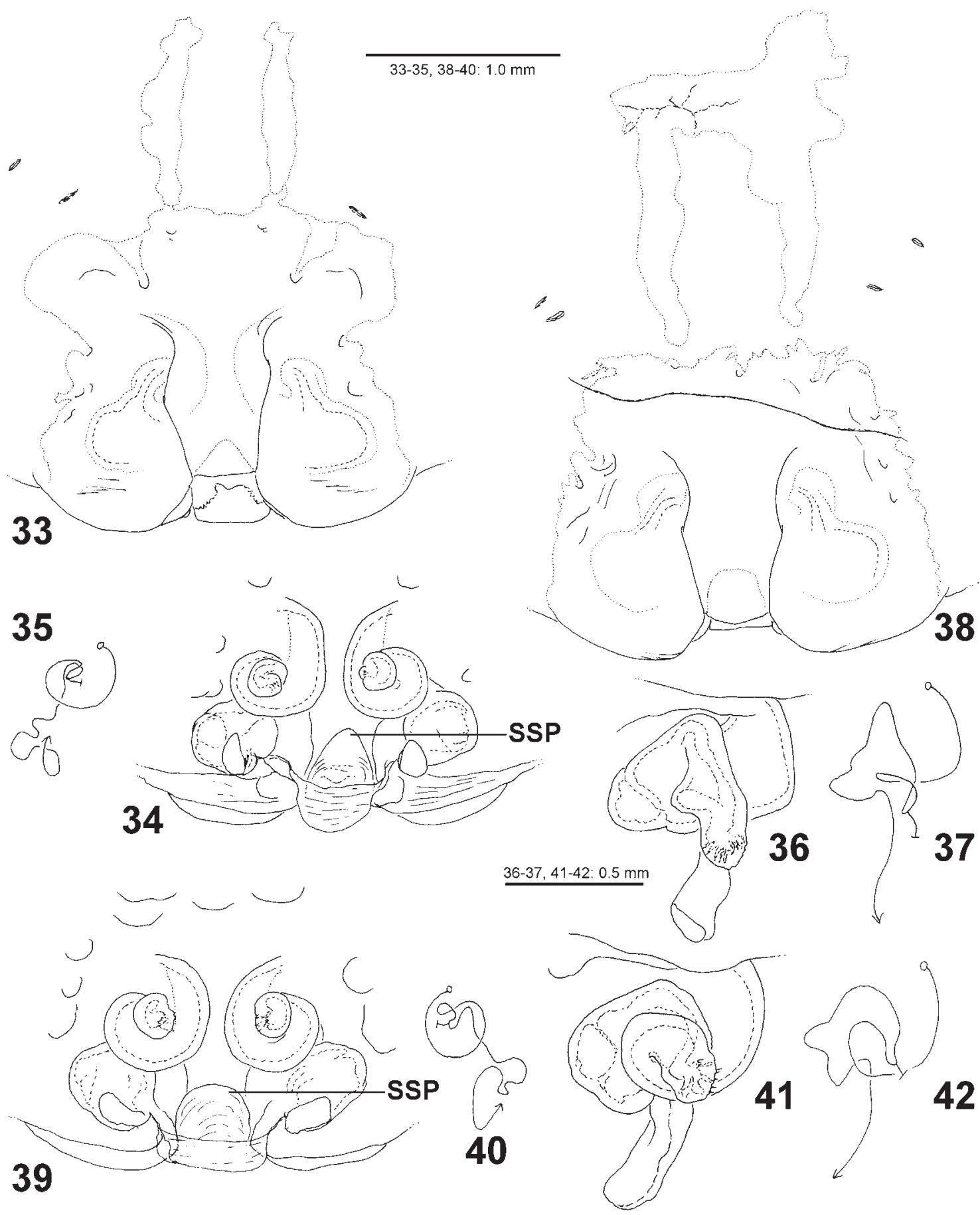

Figs 33-42. Heteropoda opo sp.n. from Burma, female copulatory organ of paratypes (33-37 PJ 3151, 38-42 PJ 3150). 33, 38 epigyne, ventral; 34, 36, 39, 41 - internal duct system (34, 39 - dorsal, 36, 41 - frontal); 35, 37, 40, 42 - schematic course of internal duct system. SSP - subseptal pocket.

Рис. 33-42. Heteropoda opo sp.n. из Бирмы, эпигина паратипов (33-37 РЈ 3151, 38-42 РЈ 3150). 33, 38 - эпигина, вентрально; 34, 36, 39, 41 - эндогина (34, 39 - сверху, 36, 41 - спереди); 35, 37, 40, 4232 - схема канальцев эндогины. SSP - карман под суптумом.

Jäger, 2000 in having a similar size range, colour pattern (esp. banded legs and dorsal shield of prosoma, Figs 54-56) and similar copulatory structures (Figs 33-47), but may be recognised by the following differences: 1. median septum generally broader (Figs
33, 38, 43; narrower in $H$. maxima), 2. internal duct system with turning point of first winding with glandular parts situated centrally (Figs 34, 39, 44; situated laterally in H. maxima) and its anterior rim bent distinctly anterio-laterally (mainly anteriad in $H$. maxi- 


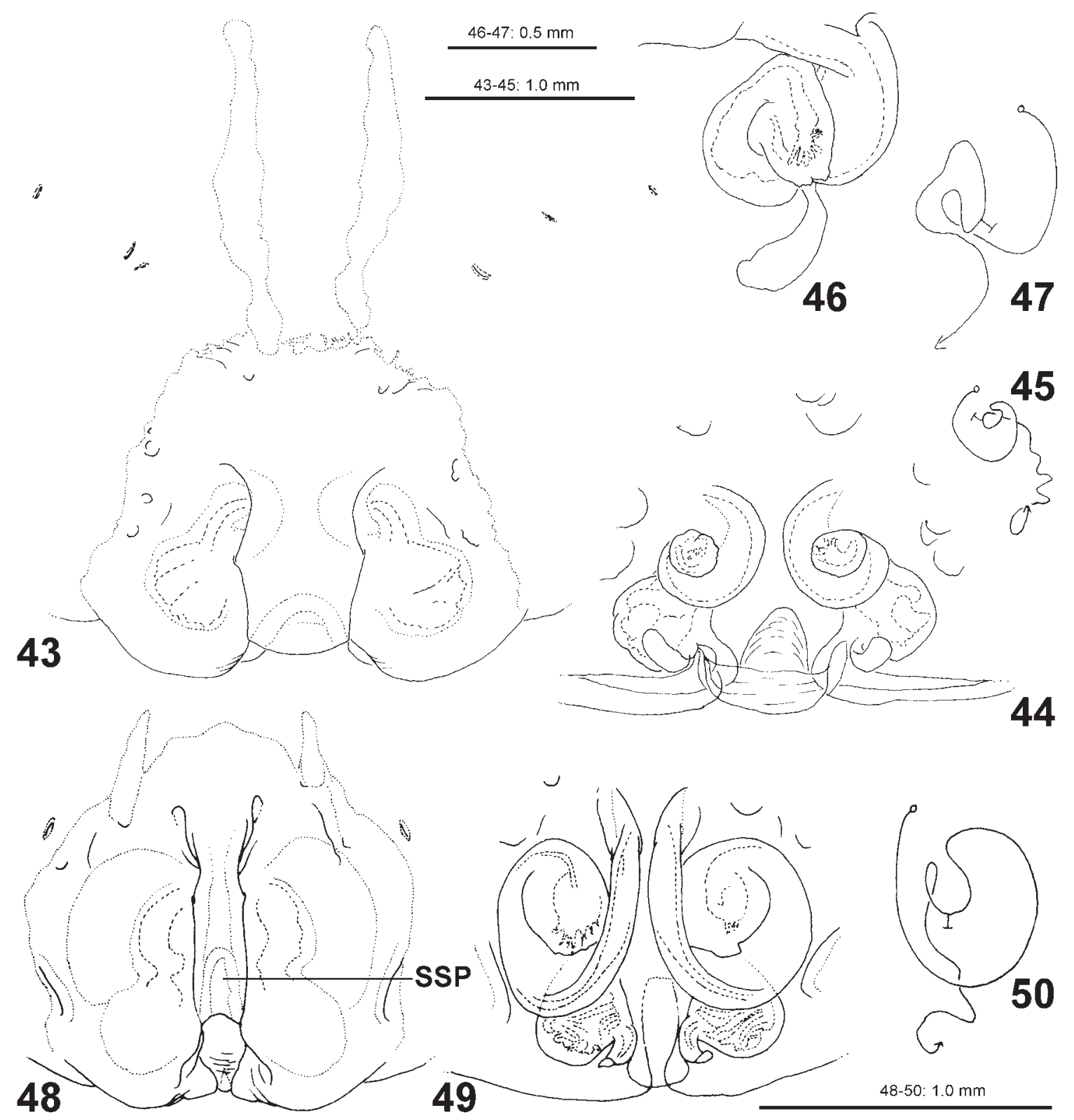

Figs 43-50. Female copulatory organ. 43-47 - Heteropoda opo sp.n. from Burma, holotype. 48-50 - H. languida Simon 1887 from Burma, holotype. 43, 48 - epigyne, ventral; 44, 46, 49 - internal duct system (44, 49 — dorsal, 46 — frontal); 45, 47, 50 - schematic course of internal duct system. SSP - subseptal pocket.

Рис. 43-50. Эпигина. 43-47 — Heteropoda opo sp.n. из Бирмы, голотип. 48-50 - Heteropoda languida Simon 1887 из Бирмы, голотип. 43, 48 - эпигина, вентрально; 44, 46, 49 - эндогина (44, 49 — сверху, 46 — спереди); 45, 47, 50 - схема канальцев эндогины. SSP — карман под суптумом.

$m a)$, 3. fertilisation ducts separated by well more than one diameter of the first winding (Figs 34, 39, 44; separated by just one diameter of the first winding in H. maxima). 4. dorsal pattern of prosoma with dark transversal band with entire anterior margin (Figs 5456; serrated in H. maxima) and more uniformly coloured part in front of that band (with distinct radial markings in $H$. maxima).

DESCRIPTION. Female (holotype). Prosoma length 16.4 , width 14.5 , anterior width 7.6 , opisthosoma length
26.1, width 15.0. Eyes: AME 0.62, ALE 1.05, PME 0.84, PLE 1.07, AME-AME 0.32, AME-ALE 0.10, PME-PME 0.49, PME-PLE 0.77, AME-PME 0.73, ALE-PLE 0.82, clypeus height at AME 1.62, at ALE 1.05. Spination: palp: 131, 101, 2121, 1014; legs: femur I-III 323, IV 33(2)1; patella 101; tibia I 2226, II 22(3)26, III 2226, IV 2126; metatarsus I-II 1014, III 2014, IV 3036. Metatarsus IV ventrally with many bristles along entire length in several rows distally embedded in scopula, ventral metatarsus III with sev- 

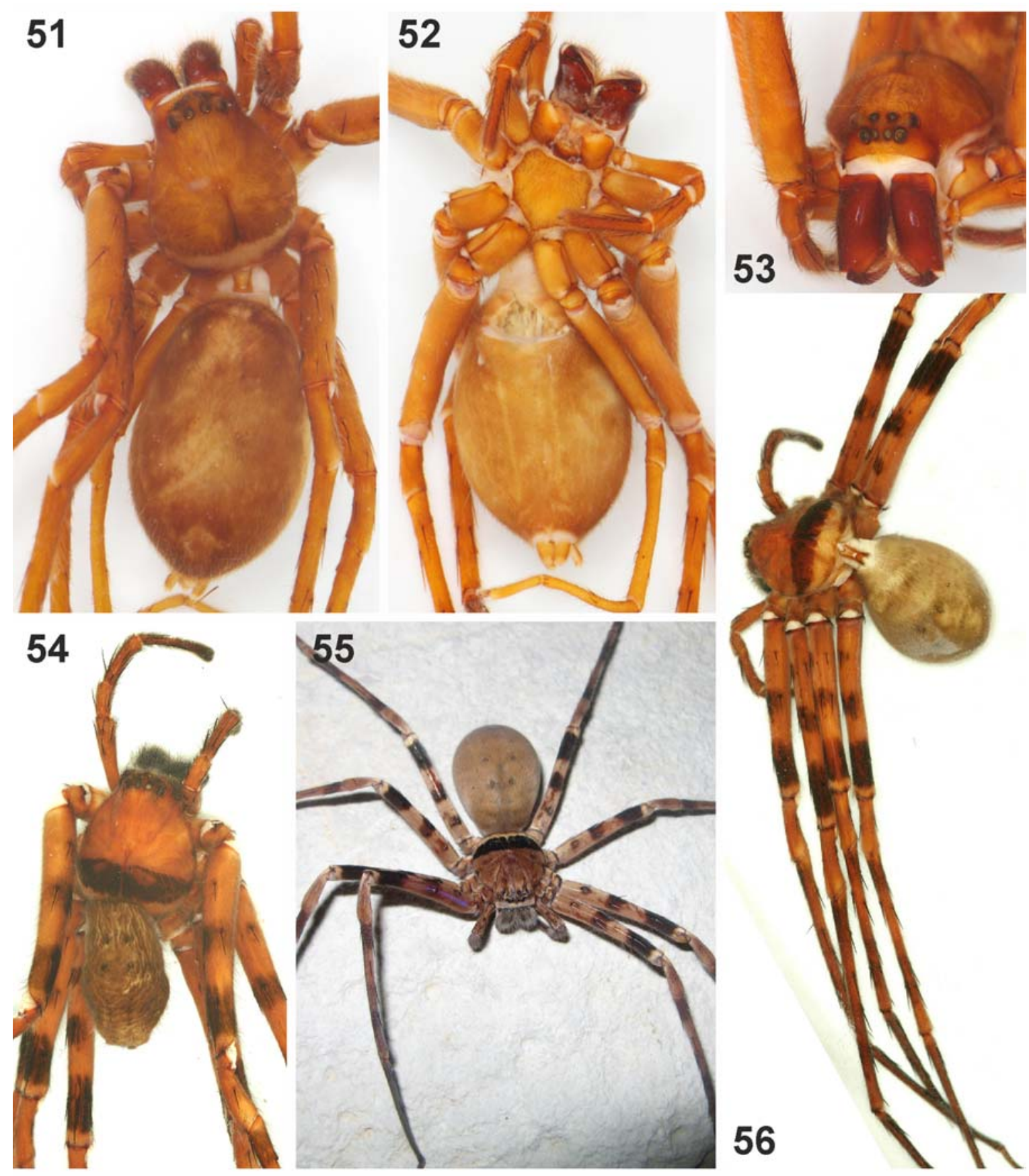

Figs 51-56. Habitus of preserved $(51-54,56)$ and live (55) spiders. 51-53 - Heteropoda pekkai sp.n. from Bhutan, holotype. 54-56 H. opo sp.n. from Burma, holotype (56), paratypes (54-55). 55 - by courtesy of Liz Price.

Рис. 51-56. Габитус фиксированных (51-54, 56) и живых (55) пауков. 51-53 - Heteropoda pekkai sp.n. из Бутана, голотип. 54-56 - H. оро sp.n. из Бирмы, голотип (56), паратипы (54-55). 55 — с разрешения Liz Price.

eral bristles in proximal half. Leg formula: 2143. Measurements of palp and legs: palp 29.6 (8.9, 4.2, 7.4, -, 9.1), leg I $94.7(24.7,9.4,28.8,26.5,5.3)$, leg II 103.1 $(28.0,9.7,31.7,28.2,5.5), \operatorname{leg}$ III $84.5(23.8,8.4,25.1$, $22.6,4.6)$, leg IV $93.5(25.6,8.1,27.8,26.8,5.2)$ Cheliceral furrow with ca. 115 denticles situated in one patch close to the three promarginal teeth. Promargin of chelicerae with 3 teeth, retromargin with 4 teeth. Palpal claw with 9-10 teeth. Retrolateral leg claw II with 13 teeth.

Copulatory organ as in diagnosis (Figs 33-47). Epigynal field variable in shape, with moderate to long anterior bands. Median septum freely visible, with subtriangular to semi-circular subseptal pocket. 3-6 slit 


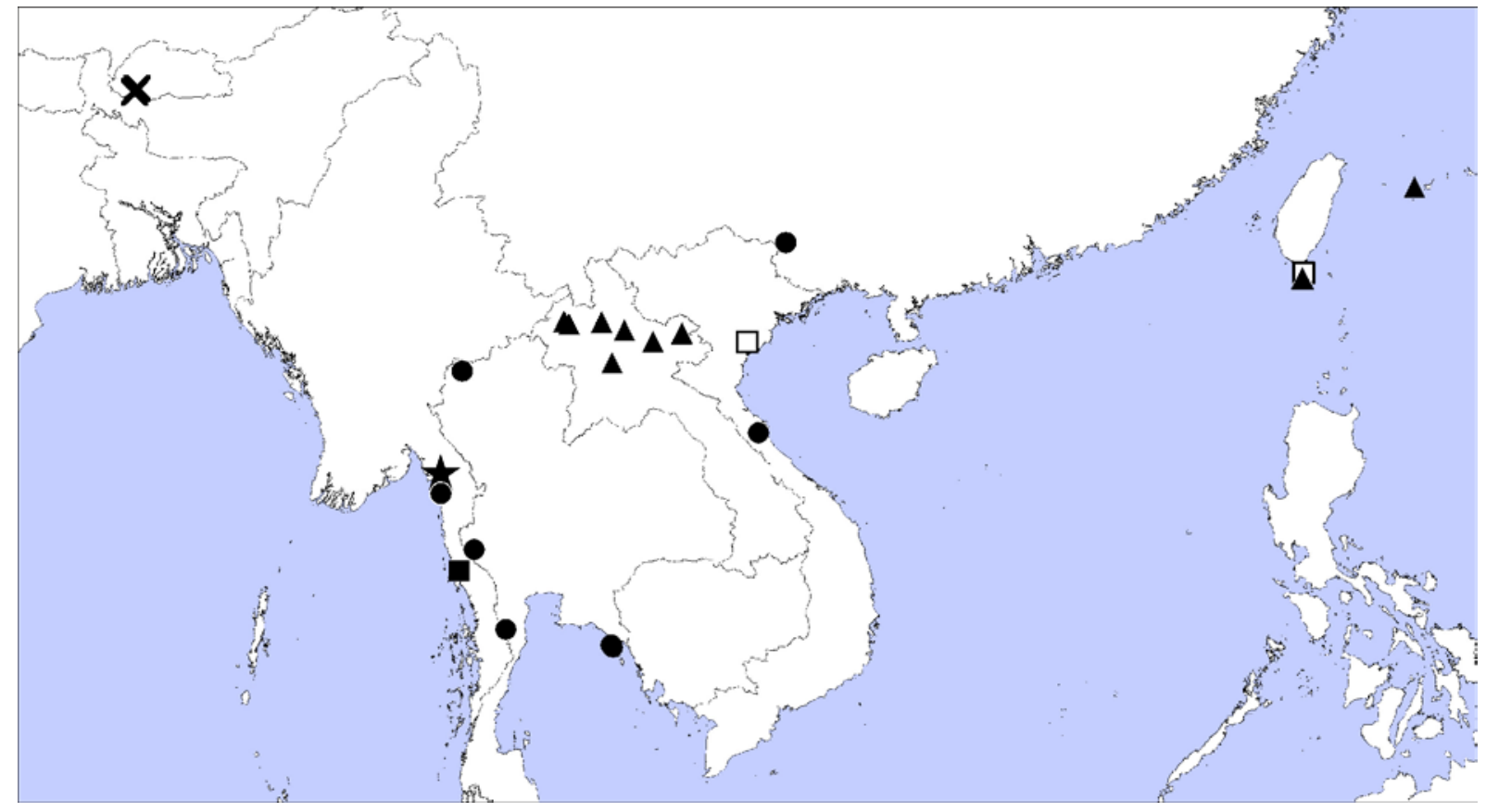

Fig. 57. Map of Heteropoda species in South and Southeast Asia. Cross - H. pekkai sp.n.; circle - H. tetrica; star - H. opo sp.n.; filled square $-H$. languida; triangle $-H$. simplex; open square $-H$. zuviele. The map compiles partly additional records from previously published data in order to show the presently known range of distribution.

Fig. 57. Распространение видов Heteropoda в южной и юго-восточной Азии. Крест - H. pekkai sp.n.; круг — H. tetrica; звезда H. opo sp.n.; квадрат (залитый) — H. languida; тругольник - H. simplex; квадрат (незалитый) - H. zuviele. Карта включает часть ранее опубликованных точек.

sensilla, separated partly distinctly from epigynal field. Internal duct system with glandular pores mediad. Fertilisation ducts separated by distinctly more than one width of the first winding. Numerous muscle attachment points around internal duct system.

Colouration (Figs 54-56). Generally reddish-brown with dark brown pattern. Dorsal shield of prosoma with distinct transversal band in posterior half reaching lateral margins, followed by a bright transversal band at posterior margin; rest almost without pattern except for slightly marked posterior margin and indistinct radial pattern in anterior half. Chelicerae almost entirely dark reddish-brown to black. Palps without pattern becoming darker distally. Femora with spine patches, except for distal spines. The latter included in dark distal annulate patches with a subdistal bright band. Tibiae with indistinct spine patches, metatarsi and tarsi darker than proximal segments. Opisthosoma dorsally greyish-brown with muscle sigilla darkly marked, ventrally without pattern.

Male. Unknown.

VARIATION. 2 + 9 paratypes: prosoma length 14.0 15.3, width 12.6-13.7, anterior width 6.5-7.3, opisthosoma length 16.6.-20.4, width 9.6-11.8. Spination: femora IV 331; tibiae I 22(1)26, II 22(1)26, III 22(1)26, IV 2126. One paratype (PJ 3150) with 5 posterior cheliceral teeth on one chelicerae. Palpal claw with 8 10 teeth. Leg claws in one paratype (PJ 3150) with distinctly shorter primary tooth, probably by more abrasion due to an older age.
DISTRIBUTION. The species is known from Burma, Kayin State, Hpa-An, from two caves: Hai Sin Gu, and Saddan $\mathrm{Gu}$,which are situated in one massif about 450 air meter apart (Fig. 57: star).

RELATIONSHIPS. This species may well be closely related to $H$. maxima and $H$. steineri Bayer et Jäger, 2009. Female copulatory organs of $H$. maxima and $H$. opo sp.n. are similar, whereas $H$. steineri turned out to be sister species to $H$. maxima in a preliminary molecular analysis [Bayer \& Jäger, unpublished]. Until no males of the new species are known I refrain from establishing a new species group. Descriptive characters of the new species are: posterior part of internal duct system distinctly wider than part with first winding, median septum broad and clearly visible, epigynal field with distinct and narrow anterior bands. Since these characters occur in many other Heteropoda species, a systematic placement is not possible without males. One male was found in a cave ca. 46 air km south of the type locality (Nga Gar Mauk Gu), but was identified as $H$. tetrica according to morphological characters (see below). The conspecifity of the male with $H$. tetrica was confirmed by an analysis of CO I-gene sequences of both species [Bayer \& Jäger, unpublished]. Heteropoda tetrica is known as abundant species and occurs also in caves, especially in their entrance zones. Males have been confused even with those of $H$. maxima in Laos [e.g., Fritzsche \& Zompro, 2008]. 


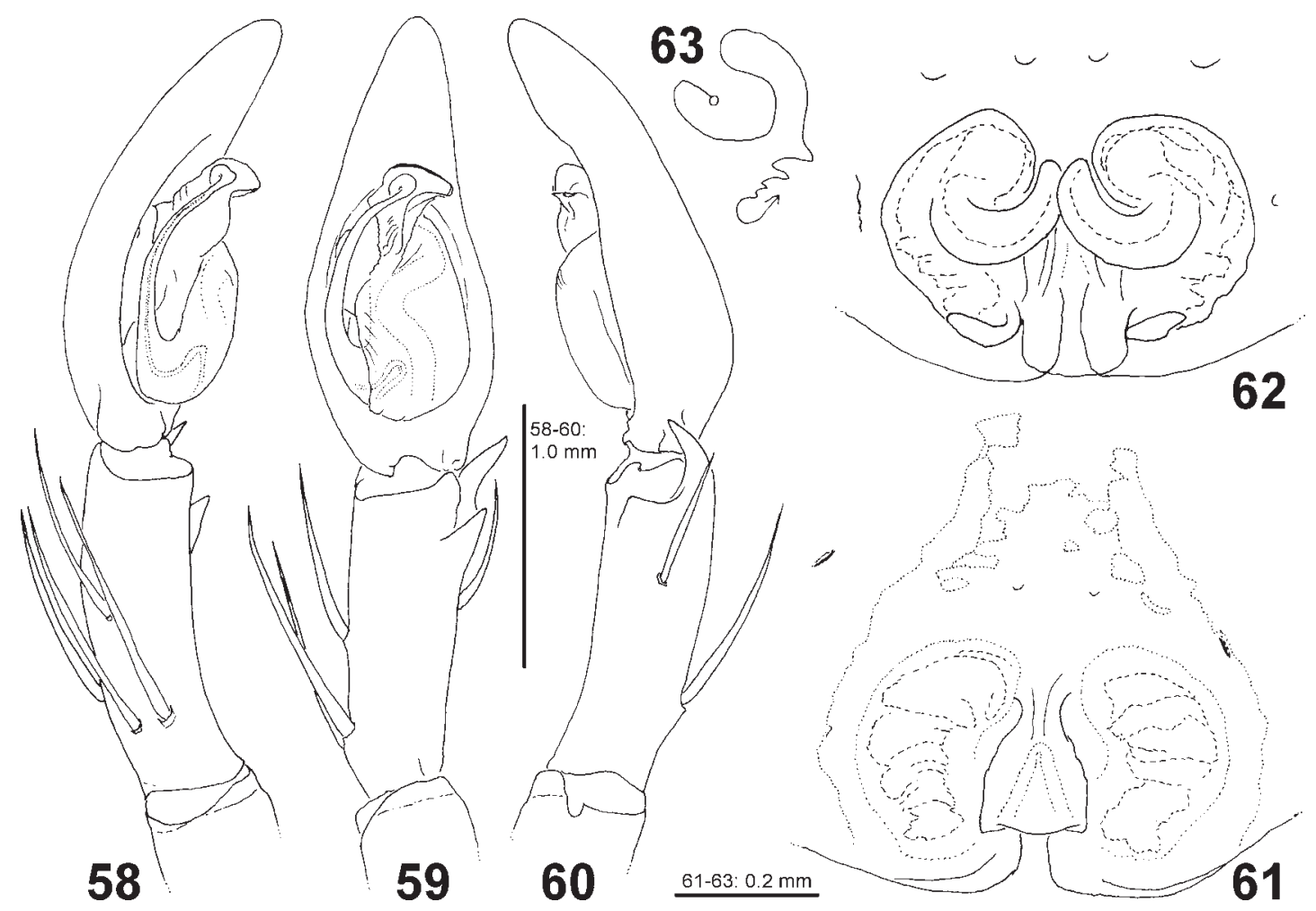

Figs 58-63. Heteropoda parva from Kalimantan, copulatory organs. 58-60 - left male palp (58 - prolateral, 59 - ventral, $60-$ retrolateral); 61 - epigyne, ventral; 62 - internal duct system, dorsal; 63 - schematic course of internal duct system.

Рис. 58-63. Heteropoda parva из Калимантана, копулятивные органы. 58-60 - левая пальпа самца (58 - пролатерально, 59 вентрально, 60 - ретролатерально); 61 - эпигина, вентрально; 62 - эндогина, сверху; 63 - схема канальцев эндогины.

\section{Heteropoda tetrica Thorell, 1897}

MATERIAL EXAMINED. CHINA: 1 (PJ 3359), Yunnan, Gaoligong Shan, $22^{\circ} 54.439^{\prime} \mathrm{N}, 106^{\circ} 57.456^{\prime} \mathrm{E}, 1600 \mathrm{~m}$, J. Martens, 4.6.2011, by hand (SMF 62114). BURMA: $10^{7}$ (PJ 3148), Kayin State, Nga Gar Mauk Gu, 16 $19^{\prime} 4.3^{\prime \prime} \mathrm{N}, 97^{\circ} 42^{\prime} 20.4^{\prime \prime} \mathrm{E}$ [32 m], in cave, ca. $40 \mathrm{~m}$ from cave entrance, H. Steiner, 3.2.2009, 012/09, NE 47-14-008, Northern Lao-European Cave Project, SD 608 (SMF). THAILAND: 1 , Mae Hong Son, Pangmapha district, near Ban Nam Rin $\left[19^{\circ} 27.307^{\prime} \mathrm{N}, 98^{\circ} 16.983^{\prime} \mathrm{E}, 900 \mathrm{~m}\right]$, behind base of banana leaf, D. Kovac, 1.11.2009, by hand (SMF 60464). 1 $\sigma^{7}$, Kanchanaburi, Thong Pha Phum, Reforestation Natural Center, $14^{\circ} 40.088^{\prime} \mathrm{N}, 98^{\circ} 35.678^{\prime} \mathrm{E}, 174 \mathrm{~m}$, dipterocarp forest with rocky habitat, O. Kosulic \& W. Chotwong, 22.11.2011 (SMF 63749). 2 오, Phetchaburi, Kaeng Krachan, Pala-U waterfalls, $12^{\circ} 32.021^{\prime} \mathrm{N}$, $99^{\circ} 26.949^{\prime} \mathrm{E}, 670 \mathrm{~m}$, around stream, evergreen rain forest, $\mathrm{W}$. Chotwong, 7.12.2012 (SMF 63748). 2 우, 16 juveniles (PJ 3222, 3227), Trat Province, Koh Chang, Klong Phlu School, $12^{\circ} 3.425^{\prime} \mathrm{N}$, $102^{\circ} 18.52^{\prime} \mathrm{E}, 78 \mathrm{~m}$, empty bed of stream bed with moist soil, vegetation, P. Jäger \& S. Bayer, 1.11.2009, by hand, at day, SD 658 (SMF 60442-60443). $10^{7}, 2$ 오 (PJ 3224-3226), Trat Province, Koh Chang, Hat Sai Kao, $12^{\circ} 6.778^{\prime} \mathrm{N}, 102^{\circ} 16.253^{\prime} \mathrm{E}, 48 \mathrm{~m}$, underpass, batter, forest with stream, P. Jäger \& S. Bayer, 31.10.2009, by hand, at night, SD 652, 656 (SMF 60432). $10^{7}, 1$ , 1 juv. (PJ 3228-3229), Trat Province, Koh Chang, Hat Sai Kao, $12^{\circ} 6.778^{\prime} \mathrm{N}, 102^{\circ} 16.253^{\prime} \mathrm{E}, 48 \mathrm{~m}$, forest at stream, in foliage, fern, bushes, P. Jäger \& S. Bayer, 30.10.2009, by hand, day and night, SD 653, 659 (SMF 60422-60423).

See notes above in relationships paragraph of $H$. opo sp.n. for male from Burma.
DIAGNOSIS, DESCRIPTION AND DISTRIBUTION. See Eusemann \& Jäger [2009]. Additional distributional records see Fig. 57 (circles).

\section{Heteropoda languida Simon, 1887}

Figs $48-50,57$.

Heteropoda languida Simon, 1887: 102 (description of holotype + , PJ 3174, [Burma] Tavoy $\left[14^{\circ} 5^{\prime} 5.25^{\prime \prime} \mathrm{N}, 98^{\circ} 11^{\prime} 44.28^{\prime \prime} \mathrm{E} ; 15\right.$ m], Ind. mar., MNHN 1719-8588, examined)

DIAGNOSIS. Medium sized (body length of $q$ : 13.4). Copulatory organ of female may be recognised by 1 . Long and narrow median septum with roughly parallel lateral margins (Fig. 48), 2. First winding as narrow sub-parallel part with subsequent wide circular part (Fig. 49), 3. Glandular pores posteriad (Figs 49$50)$.

REDESCRIPTION. Female (holotype). Prosoma length 6.9 , width 6.1 , anterior width 3.5 , opisthosoma length 6.5, width 4.7. Eyes: AME 0.32, ALE 0.50, PME 0.35, PLE 0.47, AME-AME 0.25, AME-ALE 0.05, PME-PME 0.40, PME-PLE 0.55, AME-PME 0.50, ALE-PLE 0.52, clypeus height at AME 0.57, at ALE 0.49. Spination: palp: 131, 101, 2121(3121), 1014(0000); legs: femur I-II 323, III 332, IV 321; patella 001; tibia 2026; metatarsus I-II 0004, III 2014, IV 3036. Ventral metatarsus IV with bristles along 


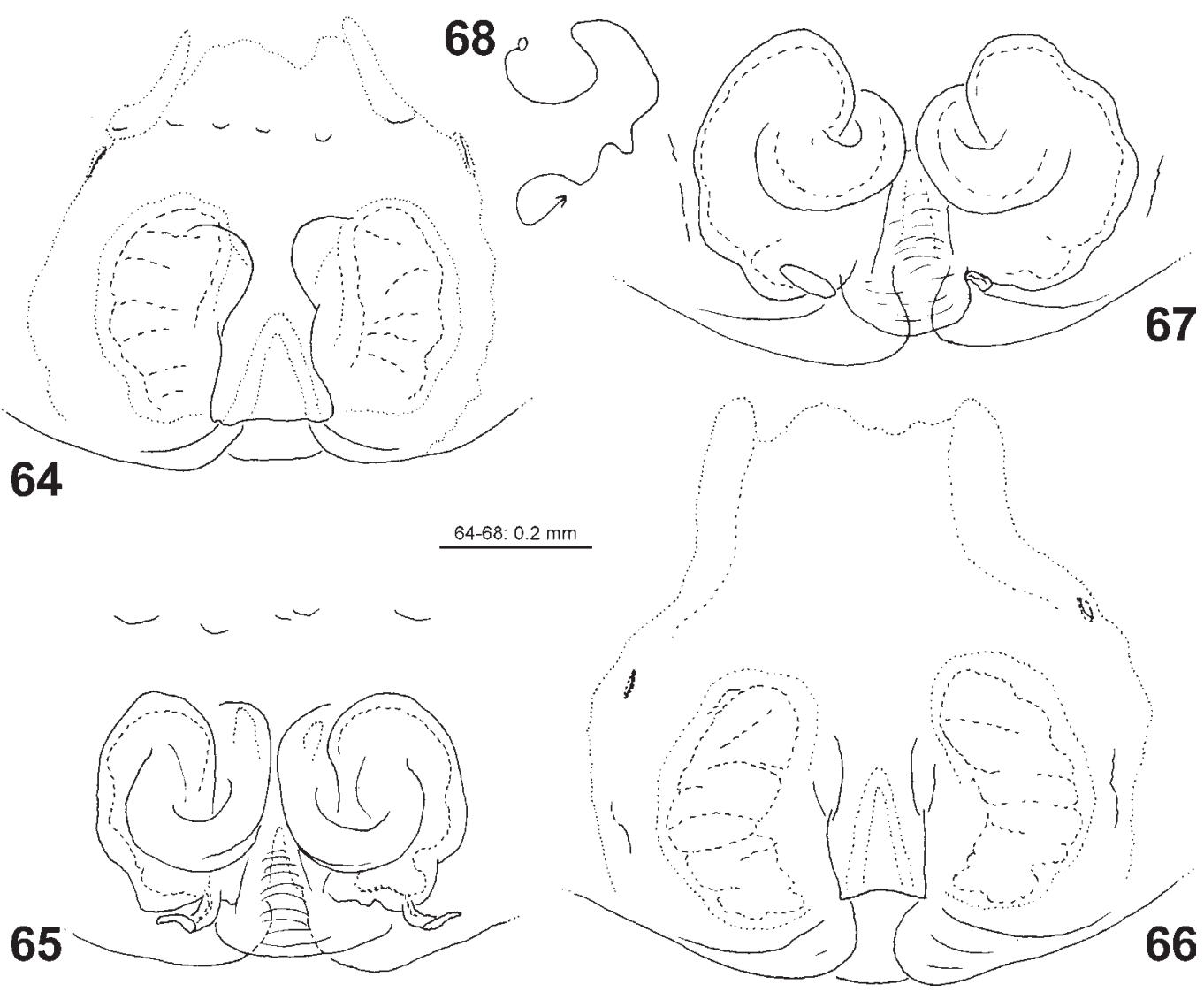

Figs 64-68. Heteropoda parva from Sarawak (64-65) and Kalimantan (66-68), female copulatory organs. 64, 66 - epigyne, ventral; 65, 67 - internal duct system, dorsal; 68 - schematic course of internal duct system.

Рис. 64-68. Heteropoda parva из Саравака (64-65) и Калимантана (66-68). 64, 66 - эпигина, вентрально; 65, 67 - эндогина, сверху; 68 - схема канальцев эндогины.

entire length, distally with numerous bristles, ventral metatarsus III only few bristles very proximally. Leg formula: 2413. Measurements of palp and legs: palp $10.6(3.0,1.7,2.6,-, 3.3), \operatorname{leg} \mathrm{I}-(7.1,3.5,7.3,6.7,-)$, leg II $29.4(8.2,3.7,8.0,7.3,2.2)$, leg III $23.5(6.7,3.0$, $6.2,5.5,2.1)$, leg IV $28.3(8.0,2.8,7.3,7.7,2.5)$. Cheliceral furrow with ca. 70 denticles situated in one elongated patch in entire cheliceral furrow. Promargin of chelicerae with 3 teeth, retromargin with 4 teeth. Palpal claw with 7 teeth.

Copulatory organ as in diagnosis (Figs 48-50). Epigynal field as long as wide with short anterior bands. Median septum with relatively long subseptal pocket. Two slit sensilla separated approximately by their length from epigynal field. Lateral lobes almost touching each other at posterior margin. Internal duct system with glandular part in the centre of first winding, glandular pores posteriad. Posterior part of internal duct system partly covered by first winding, not extending laterally beyond first winding, containing many narrow ducts. Fertilisation ducts separated by less than one width of posterior part of internal duct system.

Colouration: reddish-brown without distinct pattern recognisable due to the bad state of the holotype.
Male. Unknown (but see note below).

DISTRIBUTION. Known only from the type locality (there is more material of species with similar copulatory organs available from the former Indochina, but it cannot be stated presently with exclusively morphological data whether this is conspecific or represents different species) (Fig. 57: filled square).

RELATIONSHIPS. From the narrow median septum of the epigyne as well the winding copulatory ducts it might be related to $H$. hampsoni Pocock, 1901 from India (Nilghiri Hills) [Jäger, 2002: 50, figs 124-128].

\section{Heteropoda simplex Jäger et Ono, 2000}

\section{Fig. 57.}

MATERIAL EXAMINED. TAIWAN: $1 \sigma^{7}$ (SD 1173, SMF 64109), $1 \mathrm{O}^{7}$ (SMF 64111), 1 (SD 1183, SMF 64110), Pingtung County, Sheding Nature Park, $21^{\circ} 57.433^{\prime} \mathrm{N}, 120^{\circ} 49.222^{\prime} \mathrm{E}, 200 \mathrm{~m}$, disturbed primary forest, limestones, P. Jäger, 26.6.2013 by hand, at day.

DISTRIBUTION. The species was described from Iriomotejima Island, Okinawa Prefecture, Japan. Bayer \& Jäger [2009] recorded the species from northern Laos from caves and other habitats with high humidity. 


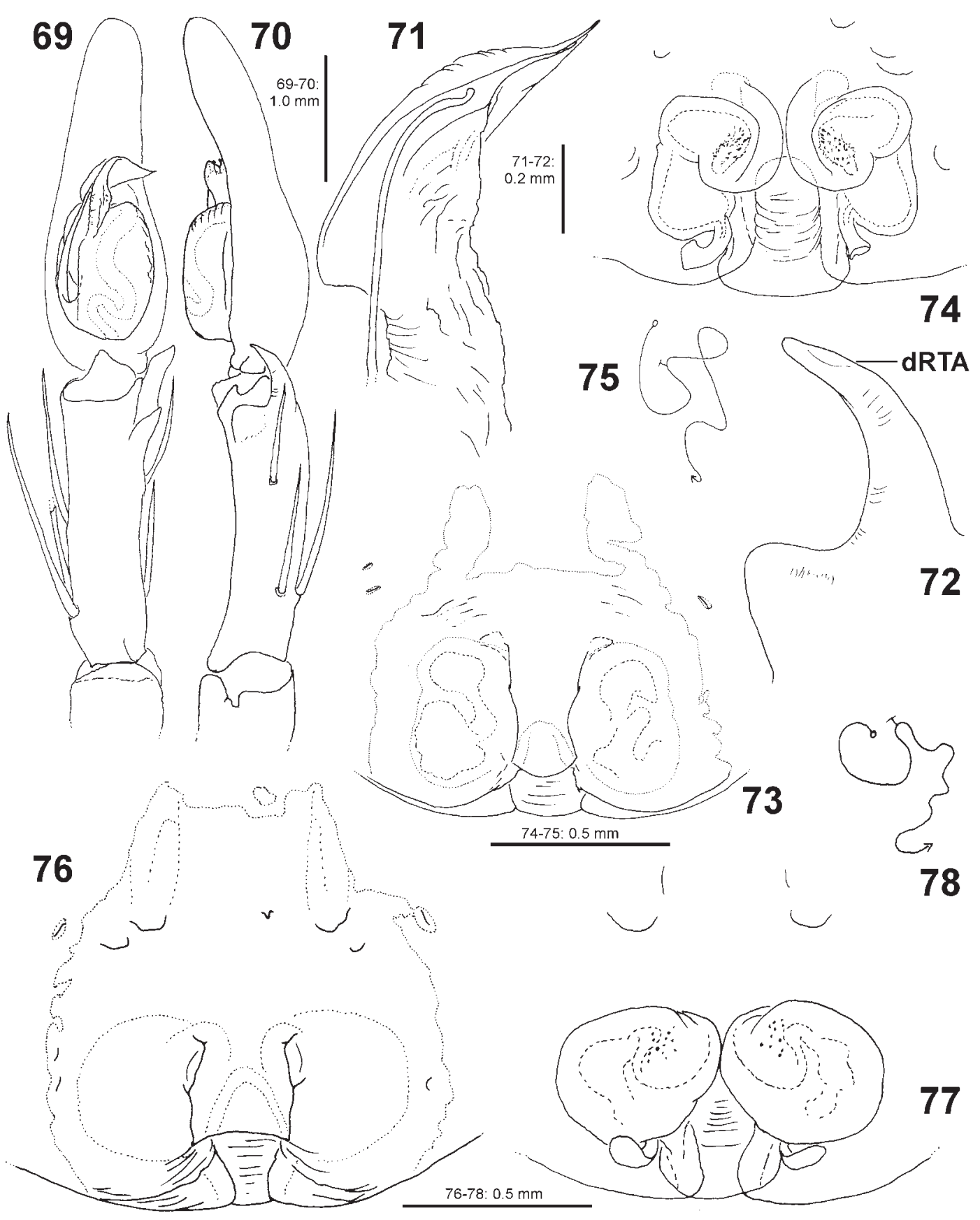

Figs 69-78. Copulatory organs. 69-72 - Heteropoda duo sp.n. from Kalimantan, holotype. 73-75 - Heteropoda sp. cf. sumatrana from Java. 76-78 - H. homstu from Java. 69-72 - left male palp (69 - ventral; 70 - retrolateral; 71 — conductor and tip of embolus, ventral; 72 - RTA, retrolateral); 73, 76 - epigyne, ventral; 74, 77 - internal duct system, dorsal; 75, 78 - schematic course of internal duct system. dRTA - dorsal part of RTA.

Рис. 69-78. Копулятивные органы. 69-72 - Heteropoda duo sp.n. из Калимантана, голотип. 73-75 - Heteropoda sp. cf. sumatrana из Явы. 76-78 - H. homstu из Явы. 69-72 - левая пальпа самца (69 - вентрально; 70 - ретролатерально; 71 кондуктор и кончик эмболюса, вентрально; 72 - RTA, ретролатерально); 73, 76 - эпигина, вентрально; 74, 77 — эндогина, сверху; 75, 78 - схема канальцев эндогины. dRTA — дорзальная часть RTA.

The present new record for Taiwan fits in the distributional range between Japan and Laos (Fig. 57: triangles). Spiders were collected at limestone rocks, where specimens ambushed in the half shade and came out of crevices shortly before dusk.
Heteropoda zuviele Jäger, 2008

Fig. 57.

MATERIAL EXAMINED. TAIWAN: 1 (PJ 3476), Pingtung County, Nan-Jen Lake [22 ${ }^{\circ} 5^{\prime} 19.90^{\prime \prime} \mathrm{N}, 120^{\circ} 51^{\prime} 46.15^{\prime \prime} \mathrm{E}, 330$ 


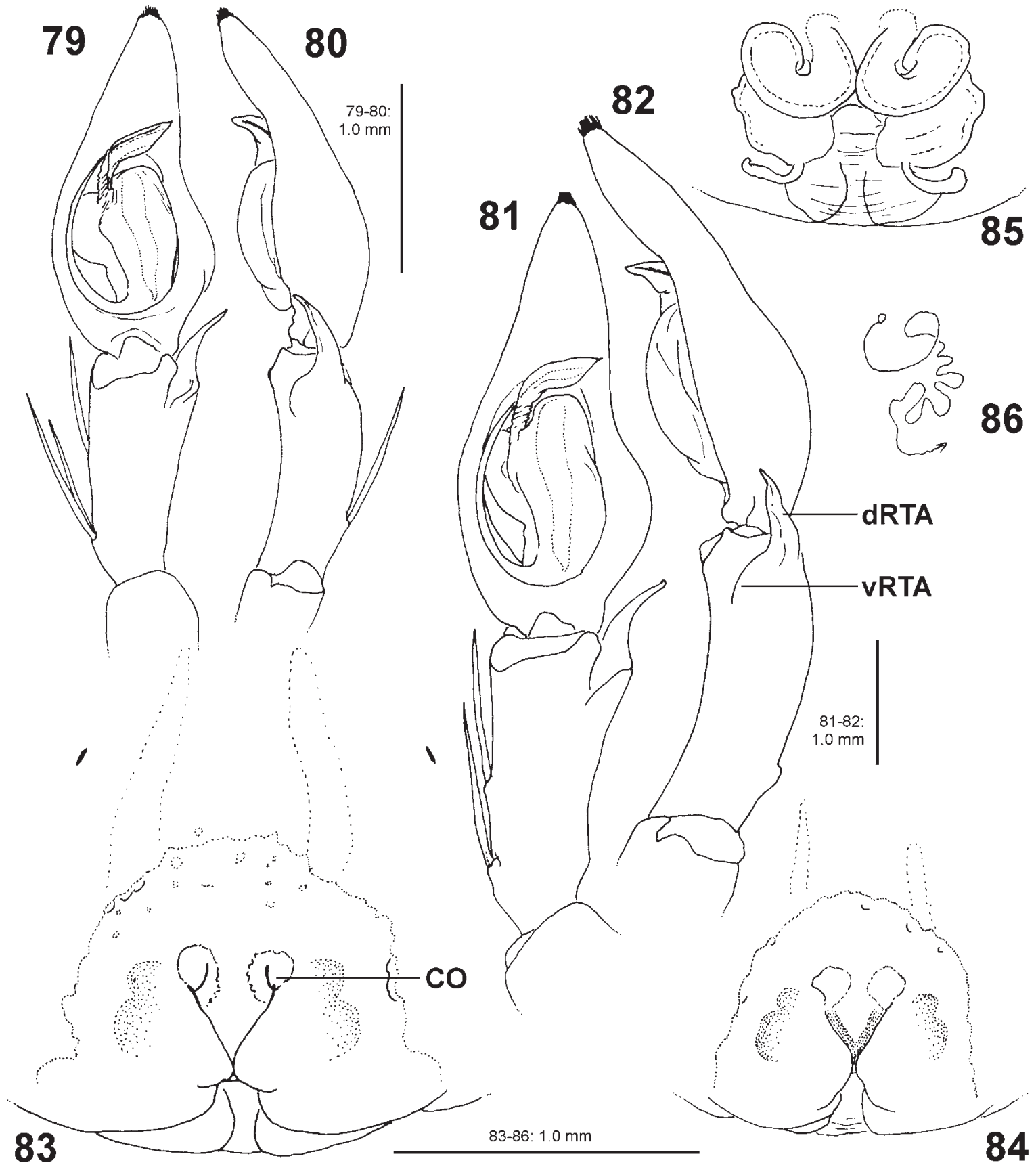

Figs 79-86. Heteropoda listeri from Christmas Islands, copulatory organs. 79-82 - left male palp $(79,81$ - ventral; 80, 82 retrolateral); 83-84 - epigyne, ventral; 85 - internal duct system, dorsal; 86 - schematic course of internal duct system. CO copulatory opening; dRTA — dorsal part of RTA; vRTA — ventral part of RTA.

Рис. 79-86. Heteropoda listeri Pocock, 1900 с о-вов Рождества, копулятивные органы. 79-82 — левая пальпа самца (79, 81 вентрально; 80, 82 - ретролатерально); 83-84 - эпигина, вентрально; 85 - эндогина, сверху; 86 - схема канальцев эндогины. $\mathrm{CO}$ - копулятивные отверстия; dRTA - дорзальная часть RTA; vRTA — вентральная часть RTA.

$\mathrm{m}]$, disturbed primary forest, rolled up leaves in shrub, C. Haddad, 26.6.2013 by hand, at day, SD 360 (SMF 64112).

DISTRIBUTION. The species was described from North Vietnam. Female copulatory organ of the Taiwanese specimen let no doubt about species identity. The species represents beside $H$. pingtungensis Zhu \& Tso, 2006 the second representative of the javana spe- cies-group in Taiwan. Moreover, it is the first record for this species from Taiwan with a considerable range extension to the East (Fig. 57: open square).

RELATIONSHIPS. This species belongs to the $j a$ vana species group. See Jäger (2008b) for more details and related species. 

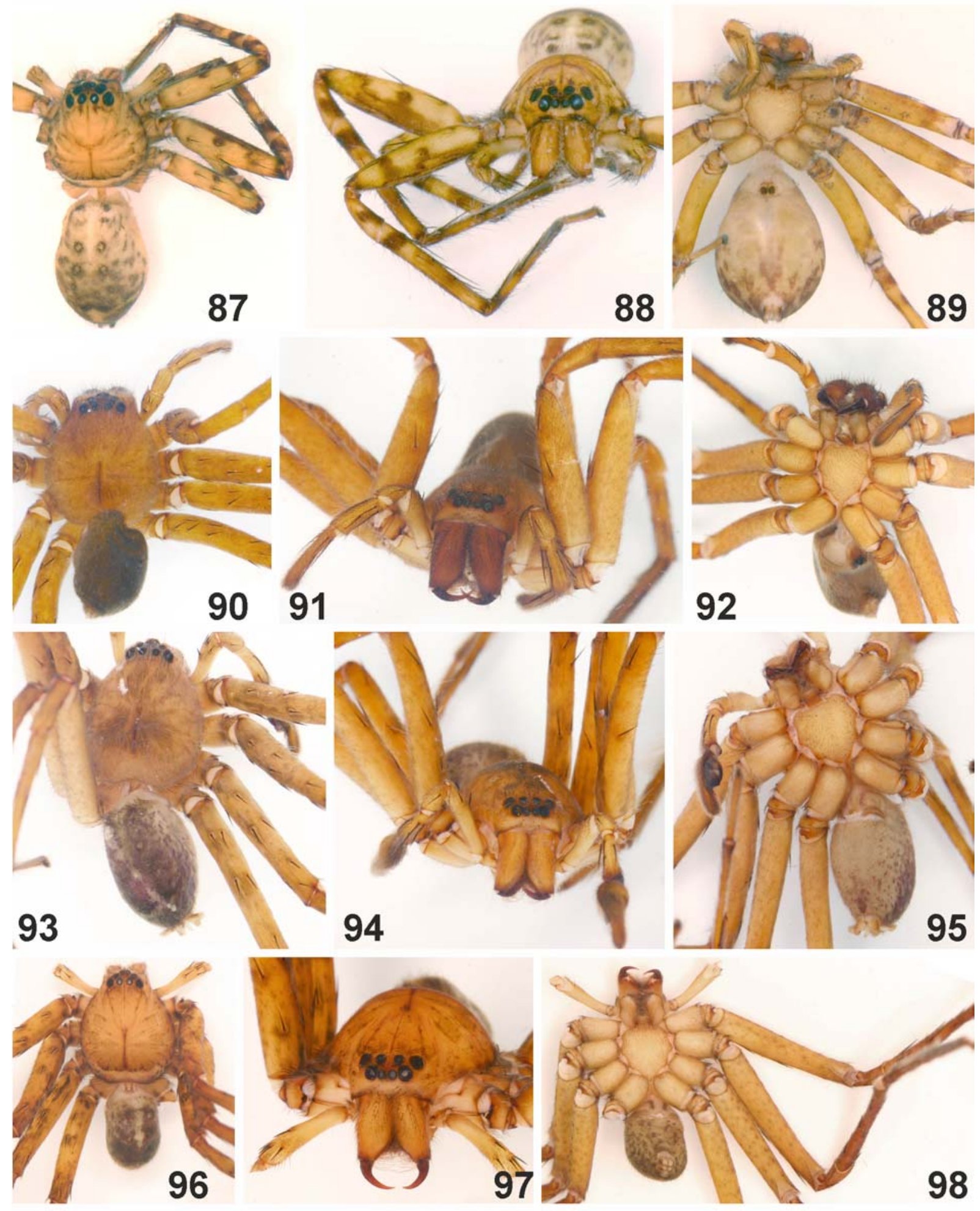

Figs 87-98. Habitus of preserved spiders (87-92 - ofo; 93-98 - $\left.0^{7} 0^{7}\right)$. 87-89 - Heteropoda parva from Kalimantan (87-88 - PJ 3143, 89 - PJ 3135). 90-95 - Heteropoda homstu from Java (90-92 - paratype PJ 2935; 93-95 - holotype). 96-98 - Heteropoda duo sp.n. from Kalimantan (holotype).

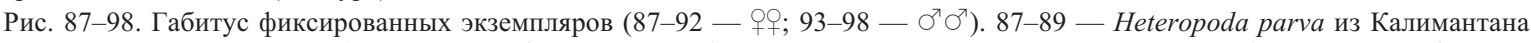
(87-88 - PJ 3143, 89 - РЈ 3135). 90-95 - H. homstu из Явы (90-92 - паратип РЈ 2935; 93-95 - голотип). 96-98 - H. duo sp.n. из Калимантана (голотип). 


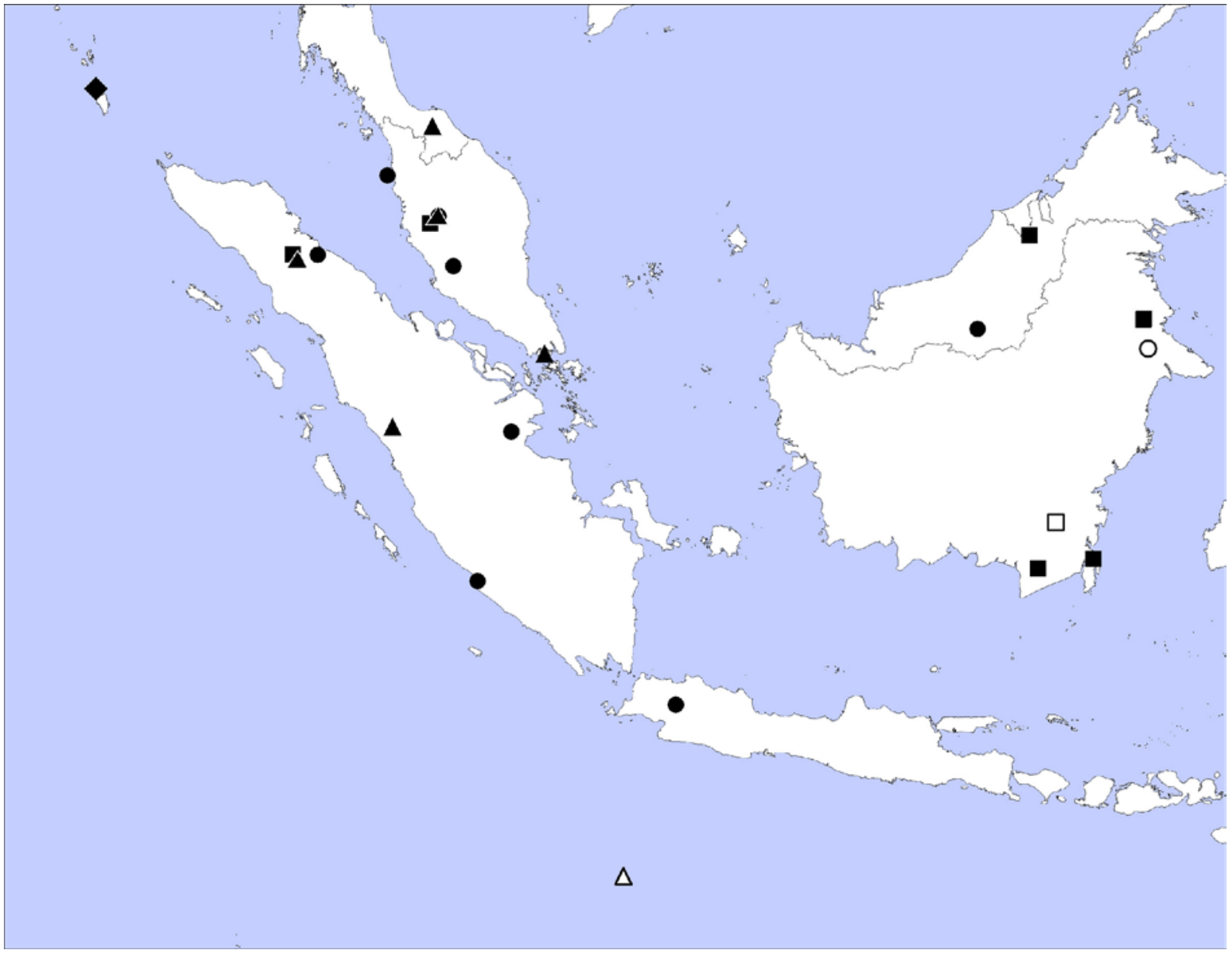

Fig. 99. Map of Heteropoda species in north-western Southeast Asia. Diamond - H. megalopis; filled square - H. parva; filled triangle $-H$. davidbowie; filled circle $-H$. boiei; open triangle $-H$. listeri; open square $-H$. kusi sp.n.; open circle $-H$. maukin sp.n. The map compiles partly additional records from previously published data in order to show the presently known range of distribution.

Fig. 99. Распространение видов Heteropoda в северо-западной части Юго-Восточной Азии. Ромб - H. megalopis; квадрат (залитый) - H. parva; треугольник (залитый) - H. davidbowie; круг (залитый) - H. boiei; треугольник (незалитый) - H. listeri; квадрат (незалитый) - H. kusi sp.n.; круг (незалитый) - H. maukin sp.n. Карта включает часть ранее опубликованных точек.

\section{Heteropoda megalopis (Thorell, 1891) comb.n.} Fig. 99.

Spariolenus megalopis Thorell, 1891: 77 (description of juvenile; 1 immature holotype [PJ 1188], Gille Nicobar Galathea putt..ies[?]) ZMUC, examined). Jäger, 2002: 58, figs 132-133).

NOTE. The label is not clearly decipherable. In the original description Thorell [1891: 78] wrote: “...in ins[ulam]. Nicobare Minore captum (G.) ...]. The Little Nicobare Islands $\left[7^{\circ} 20^{\prime} 19.67^{\prime \prime} \mathrm{N}, 93^{\circ} 39^{\prime} 15.60^{\prime \prime} \mathrm{E}\right.$, $25 \mathrm{~m}$ ] belongs to the southern group of the archipelago with a distance of roughly $230 \mathrm{~km}$ to the northern tip of Sumatra (Fig. 99: diamond).

RELATIONSHIPS. The species belongs most likely to the javana species group. Representatives of this species group are best diagnosed by features of male palps. Additional characters used include female copulatory organs as well as their colouration [Jäger, 2008b]. When describing the male of H. ocyalina (Simon, 1887) it became clear that traits of female copulatory organs are much more variable within this group than estimated before. Heteropoda species have usually an oval opisthosoma. Heteropoda ocyalina represents a rare exception [Jäger \& Bayer, 2009] together with some other undescribed species only known by their female sex. From all these evidences $H$. megalopis with its elongated opisthosoma is thought to belong to this species group, since Spariolenus immature or adults never show an elongated opisthosoma (Moradmand, personal communication). However, although the affiliation with a species group seems to be clear, the species identity cannot be clarified from the immature specimen. Therefore the species is considered a nomen dubium.

Heteropoda boiei (Doleschall, 1859)

Fig. 99.

MATERIAL EXAMINED. MALAYSIA: $1+$, Pahang, Cameron Highlands $\left[4^{\circ} 27.6^{\prime} \mathrm{N}, 101^{\circ} 24.683^{\prime} \mathrm{E}, 1400 \mathrm{~m}\right]$, F. Schneider \& 


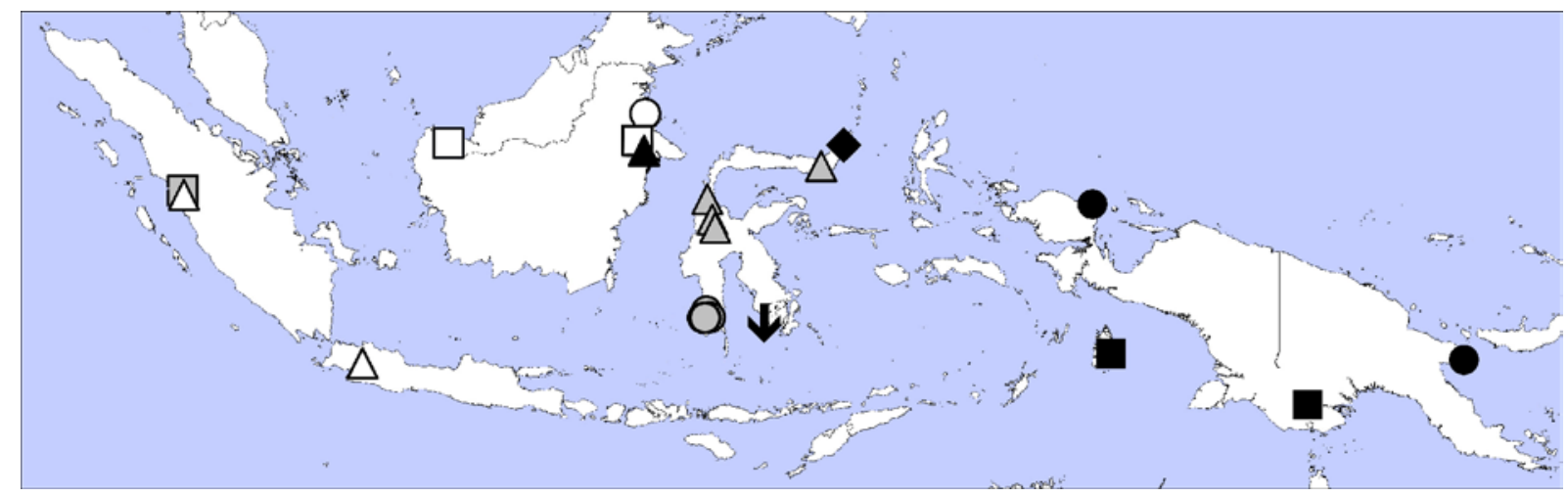

Fig. 100. Map of Heteropoda species in south-eastern Southeast Asia. Grey square - H. sumatrana; open triangle - H. sp. cf. sumatrana; open square - H. belua; open circle $-H$. duo sp.n.; black triangle $-H$. cece sp.n.; grey triangle $-H$. nigriventer; diamond $H$. obe sp.n.; grey circle - H. beroni; arrow - H. kabaenae; black square - H. analis; black circle - H. mediocris. The map compiles partly additional records from previously published data in order to show the presently known range of distribution.

Fig. 100. Распространение видов Heteropoda в северо-восточной части Юго-Восточной Азии. Квадрат (серый) - H. sumatrana; треугольник (незалитый) - H. sp. cf. sumatrana; квадрат (незалитый) - H. belua; круг (незалитый) - H. duo sp.n.; треугольник (черный) - H. сесе sp.n.; треугольник (серый) - H. nigriventer; ромб - H. obe sp.n.; квадрат (серый) - H. beroni; стрелка - H. kabaenae; квадрат (черный) — H. analis; круг (черный) - H. mediocris. Карта включает часть ранее опубликованных точек.

A. Wong, 2011 (SMF 63092). 1 subadult 9 , Malayan peninsula, offspring (F1), M. Helb ded., 23.II.2012, SD 799 (62829). 1 \% Sarawak, Sibu/Kapit $\left[1^{\circ} 54^{\prime} 35.22^{\prime \prime} \mathrm{N}, 113^{\circ} 38^{\prime} 8.14^{\prime \prime} \mathrm{E}, 15 \mathrm{~m} /\right.$ $\left.2^{\circ} 16^{\prime} 57.58^{\prime \prime} \mathrm{N}, 111^{\circ} 52^{\prime} 41.64^{\prime \prime} \mathrm{E}, 330 \mathrm{~m}\right]$, F. Schneider \& B. Cavelius, 2001 (SMF 63084).

DISTRIBUTION. The specimen from Borneo represents the first finding from this island and from East Malaysia (Fig. 99: filled circles).

\section{Heteropoda davidbowie Jäger, 2008} Fig. 99.

MATERIAL EXAMINED. MALAYSIA: $2 \sigma^{7} \sigma^{7}, 2$, $20,1 \mathrm{sub}-$ adult + , Pahang, Cameron Highlands $\left[4^{\circ} 27.6^{\prime} \mathrm{N}, 101^{\circ} 24.683^{\prime} \mathrm{E}\right.$, 1400 m], F. Schneider \& A. Wong, 2011 (SMF 63085).

One female had a body length of $26.5 \mathrm{~mm}$, which is a bit larger than the largest female listed in the original description (Jäger, 2008b: $25.3 \mathrm{~mm}$ ).

DISTRIBUTION. S Thailand, Malaysia Pensinsula, northern Sumatra (Fig. 99: filled triangles).

\section{Heteropoda parva Jäger, 2000}

Figs 58-68, 87-89, 99.

Heteropoda parva Jäger, 2000: 196, f. 1-12 (description of $\sigma^{7}+$ ); Jäger, 2008b: 275, figs 230-234 (illustration of $\Im^{7}+$ ).

MATERIAL EXAMINED. INDONESIA, BORNEO: $1 \sigma^{7}$ (PJ 3138), 1 O (PJ 3139), South Kalimantan Province, Pulau Laut, mountain above Sarang Tiung (=Gedambaan) Beach, $3^{\circ} 18^{\prime} 17^{\prime \prime} \mathrm{S}$, $116^{\circ} 15^{\prime} 46^{\prime \prime} \mathrm{E}, 200-270 \mathrm{~m}$, primary forest, P. Schwendinger, $23-$ 26.10.2008, IND-08/24, SD 602 ( $\left.\sigma^{7}\right)$, SD 603 ( + ( $)$ (MHNG). 1 (PJ 3134), South Kalimantan Province, ca. $25 \mathrm{~km}$ E of Banjarbaru, near Riamkanan Dam, $3^{\circ} 30^{\prime} 59^{\prime \prime} \mathrm{S}, 115^{\circ} 01^{\prime} 00^{\prime \prime} \mathrm{E}, 50 \mathrm{~m}$, primary forest, P. Schwendinger, 29.-31.10.2008 (MHNG). 1 O $^{\top}$ (PJ 3136), 1 (PJ 3137), East Kalimantan Province, Berau District, Hutan Wisata Sei Tangap, ca. $8 \mathrm{~km} \mathrm{~W}$ of Tanjungredeb, $2^{\circ} 08^{\prime} 04^{\prime \prime} \mathrm{N}, 117^{\circ}$ $24^{\prime} 39^{\prime \prime} \mathrm{E}, 30 \mathrm{~m}$, primary forest, P. Schwendinger, 2.10.2008, IND08/13, SD $600\left(0^{7}\right)$, SD 601 () (SMF). 1 + (PJ 3135), East Kalimantan Province, Berau District, Hutan Mayang Mangurai, ca $15 \mathrm{~km} \mathrm{SW}$ of Tanjungredeb, $2^{\circ} 06^{\prime} 13^{\prime \prime} \mathrm{N}, 17^{\circ} 24^{\prime} 05^{\prime \prime} \mathrm{E}, 20 \mathrm{~m}$, secondary forest, P. Schwendinger, 30.9.2008 (MHNG). MALAYSIA, BORNEO: 1 (PJ 1743), 1 subadult $\sigma^{\top}$, Sarawak, Mulu expedition $\left[4^{\circ} 1^{\prime} 31.28^{\prime \prime} \mathrm{N}, 114^{\circ} 49^{\prime} 5.82^{\prime \prime} \mathrm{E}, 63 \mathrm{~m}\right.$ ], MDF Plot, H.W. Vallouk[?], 2.3.1978 (NHM).
DISTRIBUTION AND VARIATION. The species was known from Malaysia (type locality: Chenderiang) and Indonesia: N Sumatra. The present material is the first record from Indonesia, Kalimantan and Malaysia, Sarawak (both Borneo) (Fig. 99: filled squares). Although there are differences in the outgrowth of the embolus tip (Figs 58-59) and in the course of the spermophor (especially the position of the loop at the embolus' base, Fig. 59) as well as in the shape of the kidney-shaped part of the female internal duct system, the longer copulatory ducts and features of the epigyne in ventral view (Figs 61-68), part of the present specimens are tentatively identified as being conspecific due to preliminary DNA results (Bayer \& Jäger, unpublished). More males may help to find out whether species or subspecies status is justified. Present specimens were slightly larger than others from Malaysia and Sumatra (body length South Kalimantan: $0^{7} 7.6$, 우 7.0-8.0; East Kalimantan: $\bigcirc^{7} 5.8$, ㅇ 6.6-7.7; Sarawak PL 3.6).

\section{Heteropoda sp. cf. sumatrana Thorell, 1890} Figs 73-75, 100.

MATERIAL EXAMINED. INDONESIA: 19 (PJ 3192), Java, Tjibodas [=Cibodas; $6^{\circ} 44^{\prime} 14.77^{\prime \prime} \mathrm{S}, 107^{\circ} 0^{\prime} 18.71^{\prime \prime} \mathrm{E}, 1330 \mathrm{~m}$ ], sub H. mediocris, E. Simon det. (MHNN 19846).

NOTES. The present female was identified by E. Simon as $H$. mediocris. Two main reasons exclude this specimen from any type status. The high subsequent collection number (19846) is "far away" from the syntype series number (1575) and therefore it was likely later examined by Simon, i.e., not at the same time as the two syntypes. Moreover, Simon "marked" type material by his initials "E.S." on the label, whereas in the case of identifications he wrote "E. Simon det." or "E. Simon" (i.e., NOT his initials), as he did in the present case. 


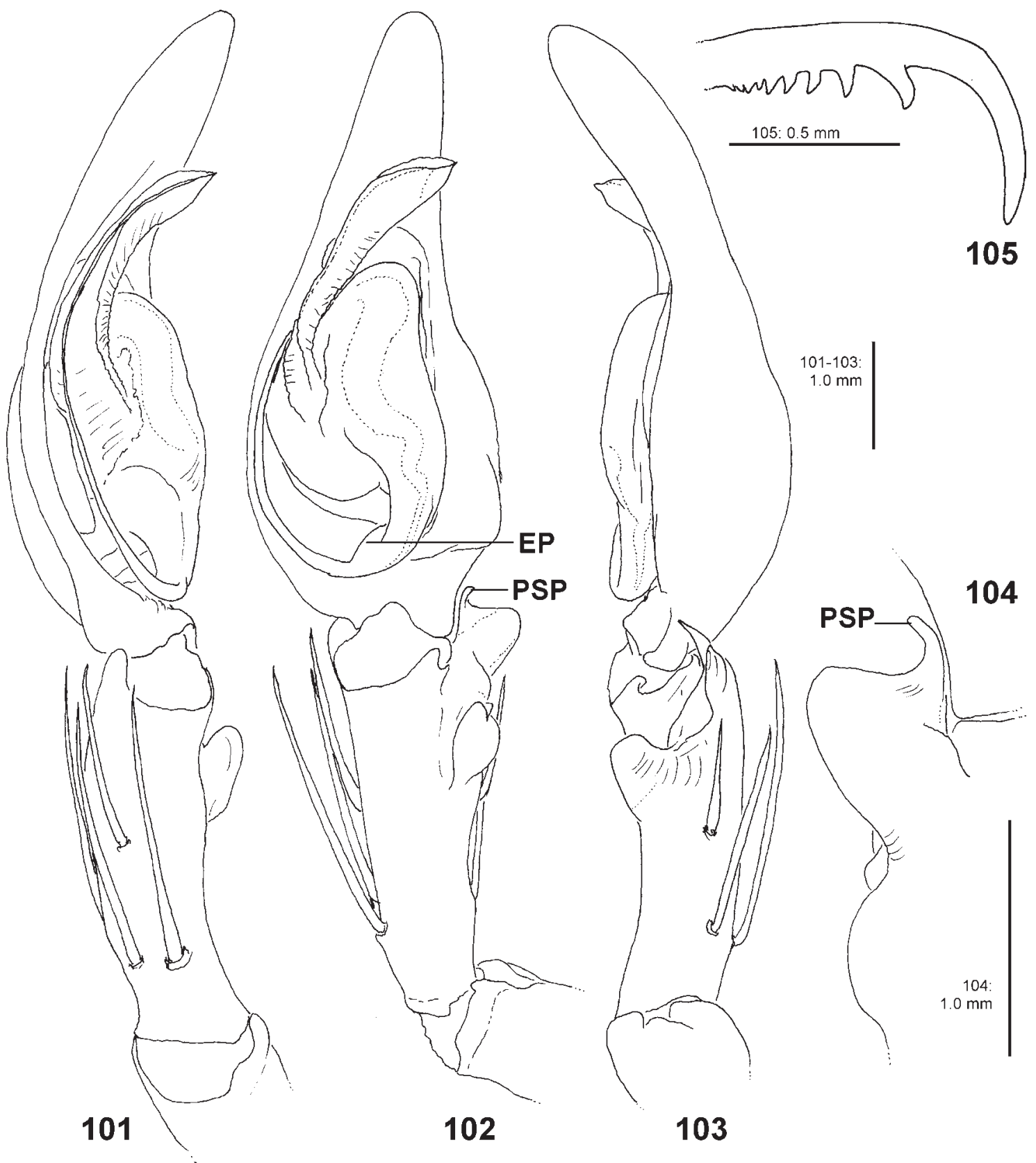

Figs 101-105. Heteropoda cece sp.n., O holotype from Kalimantan. 101-104 — left palp (101 — prolateral; 102 — ventral; 103 retrolateral; 104 - RTA, dorsal with spines omitted); 105 — claw of right leg II, retrolateral. EP — basal embolic process; PSP — pinshaped process of RTA.

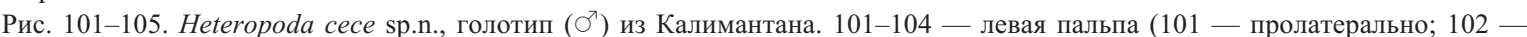
вентрально; 103 - ретролатерально; 104 - RTA, сверху); 105 - коготь правой ноги II, ретролатерально. ЕР — отросток основания эмболюса; PSP — когтевидный отросток RTA.

The present female cannot be identified unambiguously as $H$. sumatrana. Differences in the female copulatory organ (see diagnosis) may let surmise that the female is not belonging to H. sumatrana. However, without a conspecific male the identification could not be cleared without doubt. Therefore, the female is described and illustrated in detail below.
NOTE. The copulatory organ of the female is similar to that of $H$. sumatrana in having a similar internal duct system, but exhibits some differences (Figs 7375): 1. Epigynal field with longer anterior bands, 2. Anterior part of internal duct system extending anteriorly to anterior end of median septum (ventral view), 3 . Glandular pores dorsad, 4. Subseptal pocket slightly wider. The body length of female is 10.6. 


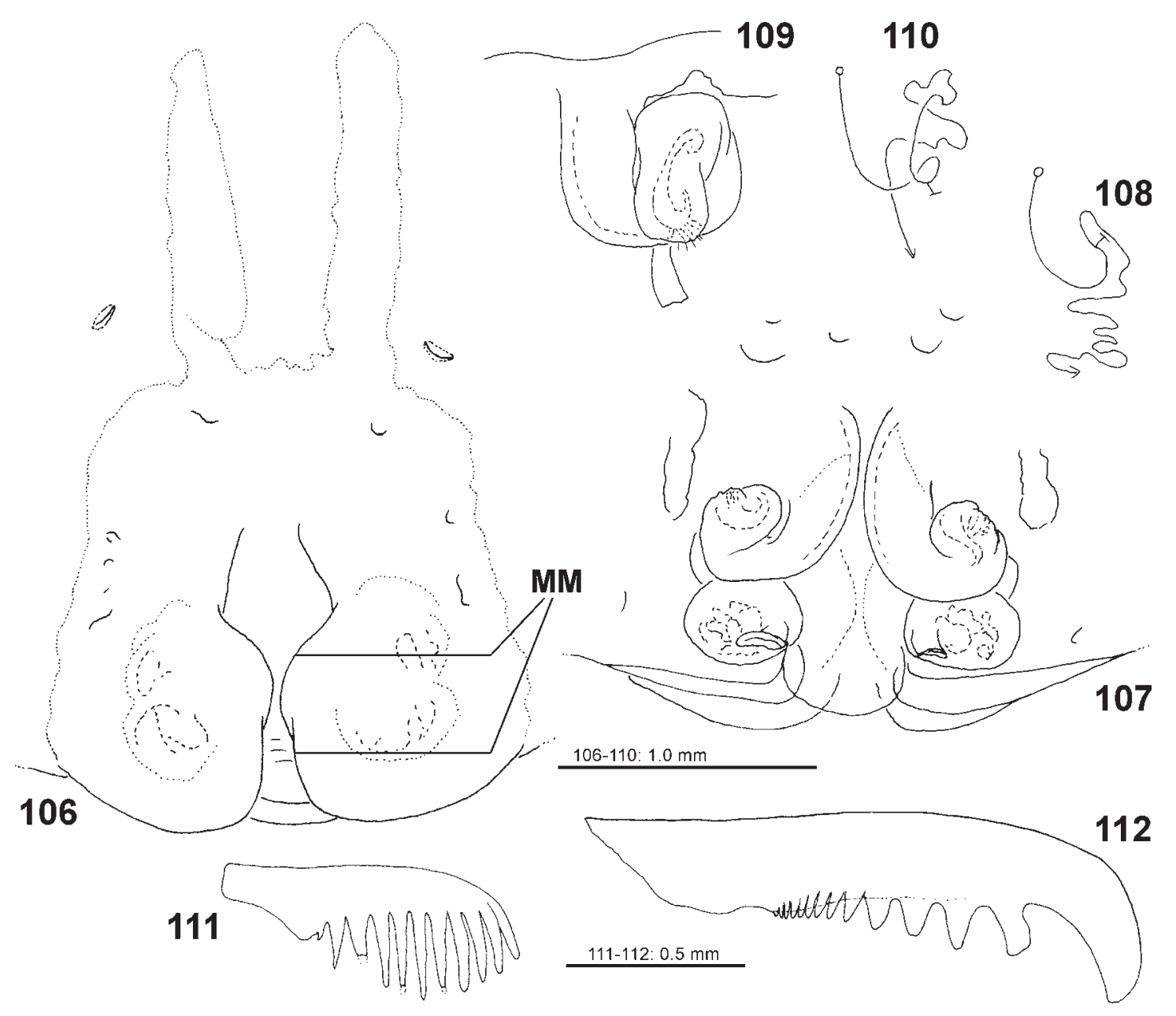

Figs 106-112. Heteropoda maukin sp.n., o holotype from Kalimantan. 106 — epigyne, ventral; 107, 109 — internal duct system (107 — dorsal; 109 - frontal); 108,110 - schematic course of internal duct system $(108-$ dorsal; $110-$ frontal $)$; 111 - claw of right palp, retrolateral. 112 - claw of left leg I, prolateral. MM - median margins of lateral lobes.

Рис. 106-112. Heteropoda maukin sp.n., голотип (†) из Калимантана. 106 — эпигина, вентрально; 107,109 - эндогина (107 — сверху; 109 - спереди); 108, 110 - схема канальцев эндогины (108 - сверху; 110 - спереди); 111 - коготок правой пальпы, ретролатерально. 112 - коготок левой ноги I, пролатерально. MM - срединные края боковых лопастей.

\section{Heteropoda homstu Jäger, 2008}

Figs 76-78, 90-95.

Heteropoda homstu Jäger 2008b: 281, f. 258-275 (description of $\sigma^{7}$ and $\rightarrow$; holotype $\sigma^{7}[\mathrm{RMNH}], 6 \sigma^{7}, 9$ 90 paratypes from Indonesia, Java and Sumatra [RMNH, SMF], examined)

MATERIAL EXAMINED. INDONESIA: 1 \% (PJ 3191; paralectotype of H. mediocris Simon 1880; see note there), Java (MNHN 1575).

NOTES. The present female is identified by its congruence of its copulatory organs clearly as belonging to H. homstu (Figs 76-78). Jäger [2008b: 283] recognised variation in the epigynal field being shorter in some individuals than illustrated [Jäger 2008b: fig. 267], which in fact is the case in this female. Total body length (12.3) fits in the range given in Jäger [2008b: 8.6-14.7]). Colouration (Figs 90-95) is illustrated additionally to the description by Jäger [2008b].
Heteropoda listeri Pocock, 1900

Figs 79-86, 99.

Heteropoda listeri Pocock, 1900: 161, pl.16, f. 4 (description

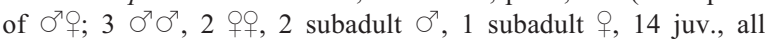
considered syntypes, Christmas Island $\left[10^{\circ} 29^{\prime} 10.54^{\prime \prime} \mathrm{S}, 105^{\circ} 36^{\prime}\right.$ 40.36"E, $233 \mathrm{~m}$ ], Camp II, East South Christmas Island, Vet., 1897, 3.[18]98, Andrews bark?, Fort Crowt? Sept. 97?, NHM 1898.10.14.71-80, examined).

DIAGNOSIS. Small to medium sized (prosoma length: 4.0-8.9). Males may be recognised by the following combination of characters (Figs 79-82): 1. RTA long and thinly tapering (in ventral view), 2. embolus arising in a 6-o'clock-position from tegulum, 3. spermophor almost straight, 4 . conductor short and widest subdistally. Females may be recognised by the following combination of characters (Figs 83-86): 1. lateral lobes of epigyne touching each other at one point (like two noses), 2. first windings of internal duct system 


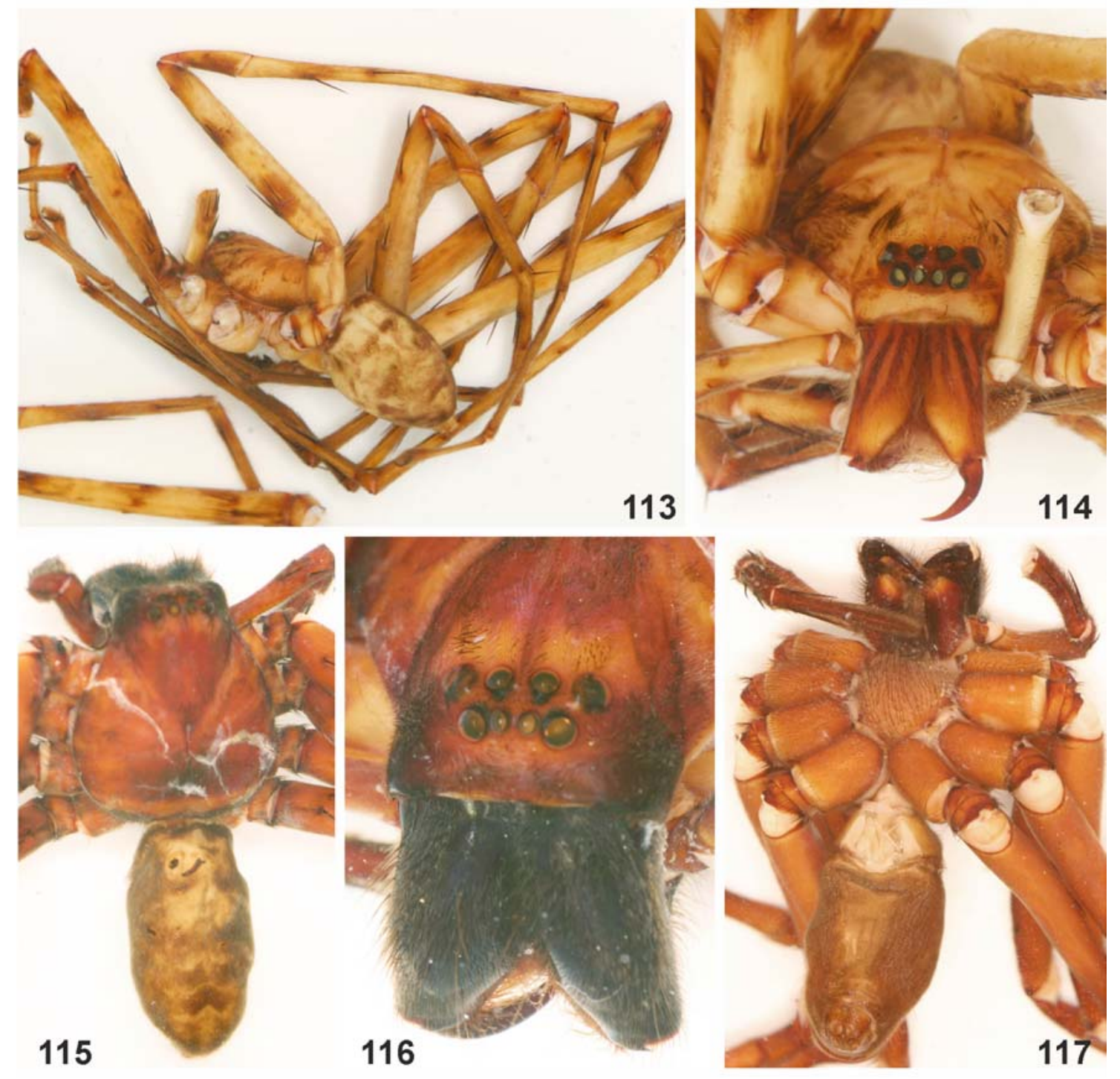

Figs 113-117. Habitus of preserved spiders. 113-114 - Heteropoda cece sp.n. from Kalimantan, ơ holotype. 115-117 - H. maukin sp.n. from Kalimantan, + holotype.

Рис. 113-117. Габитус фиксированных особей. 113-114 - Heteropoda cece sp.n. из Калимантана, голотип О’. 115-117 - H. maukin sp.n. из Калимантана, голотип ‥

almost as wide as posterior part of internal duct system, running a narrow semicircle.

REDESCRIPTION. Male. Prosoma length 4.0-8.9. Copulatory organ as in diagnosis (Figs 79-82). Cymbium slender with moderate retrolateral bulge, distinctly longer than tibia, tip with a small bunch of short bristles. Conductor arising from tegulum in a 10.30-o'clock-position. RTA with ventral and dorsal part not distinctly separated.

Female. Prosoma length 4.6-8.7. Copulatory organ as in diagnosis (Figs 83-86). Epigynal field as long as wide, with semi-circular anterior margin and partly indistinct anterior bands. In the larger female two slit sensilla present, these separated by about 7-8 times of one of their length from epigynal field. Copulatory openings close to small round bright windows at anterior part of median septum. Internal duct system with turning point latero-anteriorly.

VARIATION. Two size classes of adult specimens: $2 \sigma^{7} \sigma^{7}$ (PL 8.4, 8.9) and $1+$ (PL 8.7) are large, $1 \sigma^{\gamma}$ (PL 4.0) and 19 (4.6) are distinctly smaller. From their copulatory organs they are all conspecific. Similar size variation but without distinct clusters is known from $H$. venatoria and $H$. tetrica [Eusemann \& Jäger, 2009].

DISTRIBUTION. Known only from the type locality (Fig. 99: open triangle).

RELATIONSHIPS. The species exhibits copulatory organs similar to those of Heteropoda parva and related species from Indonesia. 


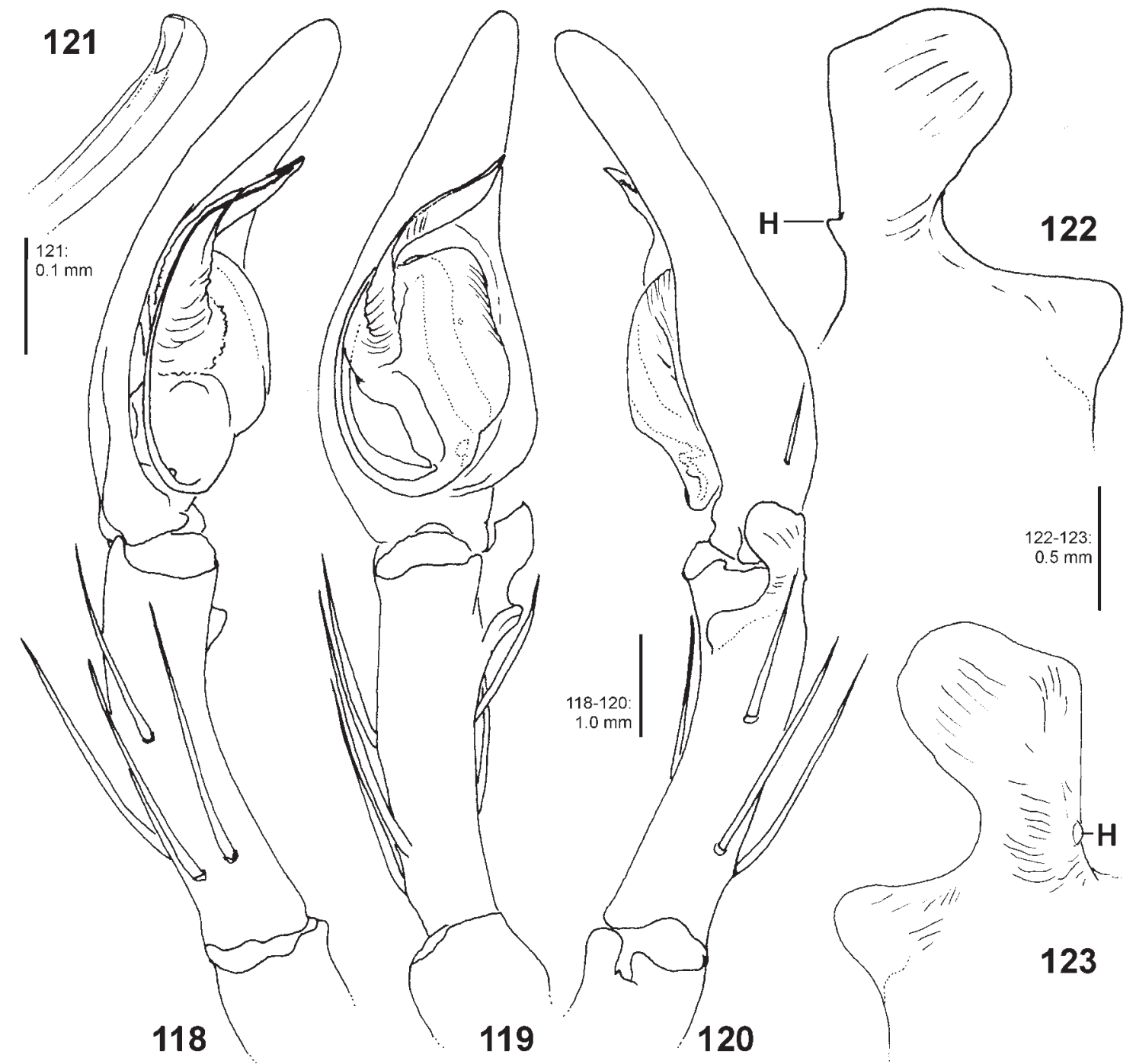

Figs 118-123. Heteropoda kusi sp.n., $\sigma^{7}$ holotype from Kalimantan, left palp (118 - prolateral; 119 - ventral; 120 — retrolateral; 121 - embolus tip, retrolatero-ventral; 122-123 - RTA, orthogonal [122 — right; 123 - left]). H — hump (tooth) of RTA.

Рис. 118-123. Heteropoda kusi sp.n., голотип О7 из Калимантана, левая пальпа (118 — пролатерально; 119 — вентрально; 120 ретролатерально; 121 - кончик эмболюса, ретролатерально-вентрально; 122-123 - RTA, ортогонально [122 - справа; 123 слева]). Н - зубчик RTA.

\section{Heteropoda duo sp.n.}

Figs 69-72, 96-98, 100.

TYPE MATERIAL. INDONESIA: Holotype O' (PJ 3133), East Kalimantan Province, Beran District, $1 \mathrm{~km}$ off road Tanjungredeb-Tanjungselor, ca. $45 \mathrm{~km} \mathrm{~N}$ of Tanjungredeb, $\mathrm{N} 2^{\circ} 29^{\prime} 33^{\prime \prime}, \mathrm{E}$ $117^{\circ} 28^{\prime} 46^{\prime \prime}, 190 \mathrm{~m}$, primary forest, P. Schwendinger, 29.9./ 3.10.2008, IND-08/07, SD 597 (MHNG).

ETYMOLOGY. The species name is derived from the Chinese term "duo", meaning among others "too much, a big amount" and referring to the human overpopulation on our planet and its negative impact on natural habitats and biological diversity; term in apposition.

DIAGNOSIS. Medium sized (body length of male: 12.8). Male palp similar to that of $H$. duan Jäger, 2008 by presence of distal bend of distal embolus (Fig. 71), but distinguished by: 1. spermophor distinctly S-shaped (Fig. 69), 2. dRTA slender, pointed (Fig. 70, 72), 3. cymbium more slender/elongate (Fig. 69), 4. conductor retrolateral tip more distinctly pointed (Figs 69, 71).

DESCRIPTION. Male (holotype). Prosoma length 6.8 , width 6.2 , anterior width 3.0, opisthosoma length 6.0, width 3.5. Eyes: AME 0.36, ALE 0.51, PME 0.40, PLE 0.48, AME-AME 0.18, AME-ALE 0.07, PMEPME 0.32, PME-PLE 0.50, AME-PME 0.42, ALEPLE 0.38, clypeus height at AME 0.63, at ALE 0.53. Spination: palp: 131, 101, 2121; legs: femur I-II 323, III 322, IV 321; patella I-III 101, IV 001; tibia I-II 2226, III 22(1)26, IV 2026; metatarsus I-II 1014, III 2014, IV 3036. Ventral metatarsus IV with many bristles along its entire length, scopula sparse, metatarsus III with few bristles in proximal half. Leg formula: 
2143. Measurements of palp and legs: Palp 10.6 (3.6, $1.7,2.5,-, 2.8)$, leg I $35.3(9.4,3.7,10.3,9.2,2.7)$, leg II $40.6(10.8,4.0,12.0,10.8,3.0)$, leg III $30.5(9.0$, $3.1,8.6,7.7,2.1)$, leg IV $34.9(9.6,2.8,9.5,10.2,2.8)$. Cheliceral furrow with about 80 denticles situated in one patch close to the three promarginal teeth and 2-3 distal denticles. Promargin of chelicerae with 3 teeth, retromargin with 4 teeth.

Male palp as in diagnosis (Figs 69-72). RTA arising distally on tibia. Cymbium elongated in comparison to $H$. duan and $H$. homstu. Conductor stout, arising in an 11-o'clock-position on tegulum, bent at right angle in ventral view, its tip distinctly pointed. Embolus arising in a 7:30-o'clock-position on tegulum.

Colouration (Figs 96-98): generally yellowish- to reddish-brown with darker brown pattern. Dorsal shield of prosoma with indistinct bright transversal band submarginally posteriorly, behind with dark marginal band, in front with darker region with small patches and indistinct radial pattern. Sternum, labium, gnathocoxae and ventral coxae pale yellowish-brown, without pattern. Chelicerae yellowish- to reddish-brown with longitudinal striae with hairs. Legs yellowish-brown on femora becoming darker, i.e. reddish-brown distally; femora with indistinct pattern of spine patches and spots, femur III with dorsal median line proximally, tibiae with very indistinct patches. Opisthosoma dorsally dark with bright area above heart and indistinct transversal band in posterior half. Opisthosoma laterally and ventrally with distinct small patches.

Female. Unknown.

DISTRIBUTION. Only known from the type locality (Fig. 100: open circle).

RELATIONSHIPS. The present species belongs to the parva species group due to their similarity of the male copulatory organ with $H$. duan as well as the presence of a slightly modified tip of embolus (see diagnosis in Jäger [2008b]).

\section{Heteropoda belua Jäger, 2005} Fig. 100.

NOTES. Dierkens [2011] recorded this species for the first time from Kalimantan Timur, the Eastern Indonesian part of Borneo (cave Lubang Bayan, $1^{\circ}$ $28.941^{\prime} \mathrm{N}, 117^{\circ} 11.539^{\prime} \mathrm{E}, 84 \mathrm{~m}$ ), ca. 700 air km from the type locality in Sarawak (Fig. 100: open square). Troglophile characters and the large size mentioned by Jäger [2005] in the original description are confirmed.

\section{Heteropoda cece sp.n. \\ Figs 100-105, 113-114.}

TYPE MATERIAL. INDONESIA, BORNEO: Holotype $0^{7}$ (PJ 3153), Kalimantan Timur, Sangkulirang, Pengadan, Gua Ampanas, $1^{\circ} 7^{\prime} 12^{\prime \prime} \mathrm{N}, 117^{\circ} 26^{\prime} 24^{\prime \prime} \mathrm{E}, 40 \mathrm{~m}$, cave, by hand, Deharveng \& Bedos, 18.8.2004, KAL-113, AmpHand (SMF).

ETYMOLOGY. The species name is derived from the beginning of the Latin term „CEterum CEnseo, progenerationem hominum esse delimitandam" ("by the way, I think, the generation of humans should be delimited") which is modified from the Roman general Cato's famous "ceterum censeo Carthaginem esse delendam", and was invented/modified and used by Bernhard Grzimek (veterinarian, ethologist, director of Frankfurt zoo, book author, film-maker; 1909-1987) as signet in each of his letters against the human population explosion; term in apposition.

DIAGNOSIS. Large sized (body length: 18.6). Male with similar palp as in $H$. belua Jäger, 2005, but may be distinguished by the following combination of characters (Figs 101-104): 1. basal embolic process smaller, rounded, not as prominent as in H. belua, 2. conductor with broad, divergent tip (convergent in $H$. belua), 3. pin-shaped process of dRTA slightly shorter and more bent as in H. belua. 4. spermophor running visibly into embolus in ventral view (running to retrolateral tegular margin in $H$. belua).

DESCRIPTION. Male. Prosoma length 9.5, width 8.7, anterior width 4.1, opisthosoma length 9.1, width 6.0. Eyes: AME 0.48, ALE 0.70, PME 0.52, PLE 0.67, AME-AME 0.26, AME-ALE 0.09, PME-PME 0.36, PME-PLE 0.57, AME-PME 0.48, ALE-PLE 0.48, clypeus height at AME 1.20, at ALE 0.95. Spination: palp: 131, 101, 2121; legs: femur I 323, II-III 333, IV 332(3); patella 101; tibia I 2226, II 22(1)26, III-IV 2126; metatarsus I-II 1014, III 2014, IV 3036. Metatarsus IV ventrally with many bristles along its entire length, distally with dense patch, metatarsus III with few bristles in proximal half. Leg formula: 2143. Measurements of palp and legs: Palp 17.6 (6.3, 2.4, 3.1, -, 5.8), leg I $74.6(19.1,5.9,22.6,21.9,5.1)$, leg II 82.9 $(21.8,6.2,25.1,24.2,5.6)$, leg III $60.7(17.0,5.2,18.5$, $16.1,3.9)$, leg IV 71.6 (19.6, 5.1, 21.0, 21.3, 4.6). Cheliceral furrow with about 160 denticles situated in one patch close to the three promarginal teeth, and 9 distal denticles. Promargin of chelicerae with 3 teeth, retromargin with 5 teeth, additional teeth smaller and situated medially. Leg claws with prominent primary tooth, claw of leg II with 9 secondary teeth (Fig. 105).

Male palp as in diagnosis (Figs 101-104). RTA arising medially to distally on tibia. Broad process of dRTA slightly larger than that of $H$. belua. Cymbium with distinct retrolateral lobe in proximal half. Conductor arising in a 9:30-o'clock-position on tegulum. Embolus arising in a 3-o'clock-position on tegulum, semi-circular.

Colouration (Figs 113-114): generally yellowishbrown with darker reddish-brown pattern. Dorsal shield of prosoma with dark hairs, the latter partly lost, therefore no distinct pattern recognisable. Sternum, ventral coxae, labium and gnathocoxae pale yellow-brown, without pattern. Chelicerae with distinct dark longitudinal bands. Leg femora with spine patches and indistinct spots between patches. Patellae darker, tibiae with indistinct spine patches. Opisthosoma dorsally with dark patches at muscle sigilla and one transversal patch in posterior half; ventrally pale yellowish-brown without pattern. 


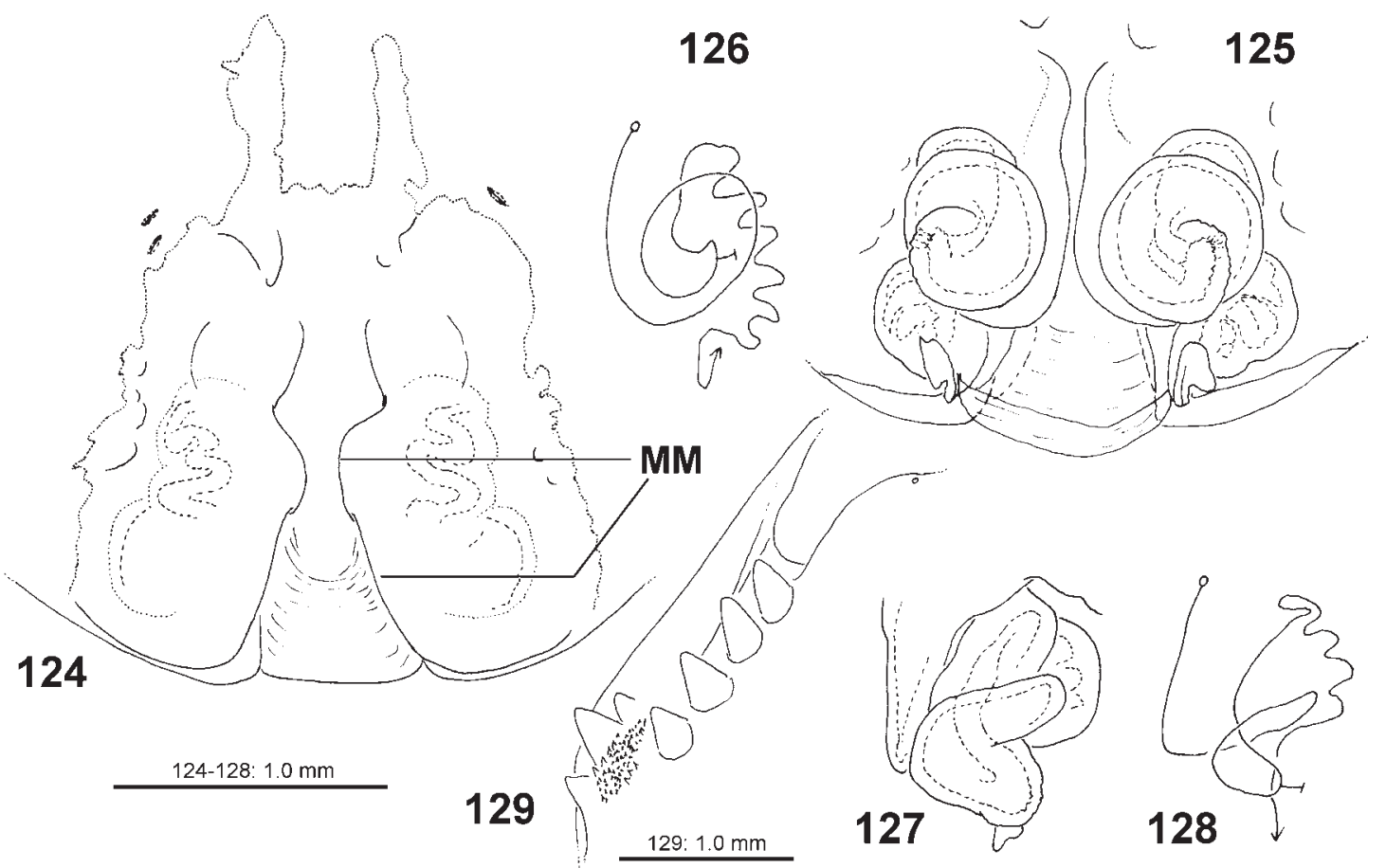

Figs 124-129. Heteropoda kusi sp.n., + paratype (124-128 — PJ 3132), ơ paratype (129 — PJ 3131) from Kalimantan. 124 — epigyne, ventral; 125, 127 — internal duct system (125 — dorsal; 127 — frontal); 126, 128 — schematic course of internal duct system (126 - dorsal; 128 - frontal). 129 - chelicerae, ventral. MM - median margins of lateral lobes.

Рис. 124-129. Heteropoda kusi sp.n., паратип (124-128 — РЈ 3132), паратип О (129 — РЈ 3131) из Калимантана. 124 эпигина, вентрально; 125, 127 - эндогина (125 - сверху; 127 — спереди); 126, 128 - схема канальцев эндогины (126 — сверху; 128 - спереди). 129 - хелицеры, вентрально. ММ - срединные края боковых лопастей.

Female. Unknown.

DISTRIBUTION. Only known from the type locality (Fig. 100: black triangle).

RELATIONSHIPS. According to derived characters of the male palp (additional process on dRTA, outgrowth on proximal embolus, course of embolus, i.e. first proximad with subsequent U-turn) closely related to H. belua.

\section{Heteropoda maukin sp.n.}

Figs 99, 106-112, 115-117.

TYPE MATERIAL. INDONESIA, BORNEO: Holotype 9 (PJ 3172), Kalimantan Timur, Sangkulirang, Tabalar, campsite cave, about $100-200 \mathrm{~m}$, ca. $10 \mathrm{~km}$ far from $1^{\circ} 27^{\prime} 36.00^{\prime \prime} \mathrm{N}, 117^{\circ} 30^{\prime}$ $36.00^{\prime \prime} \mathrm{E}$, voids between large limestone boulders, by hand, Deharveng \& Bedos, 08.8.2004, KAL-009 (SMF).

ETYMOLOGY. The species name is derived from the Xhosa term "MAsinqande UKuphuphumalisa Ilizwe Ngabantu" meaning "stop overpopulation" and stressing the negative impact of the human overpopulation on natural habitats and biological diversity; isiXhosa is the language of the tribe amaXhosa in Southern Africa (Eastern Cape Province); term in apposition.

DIAGNOSIS. Very large (body length: $33.0 \mathrm{~mm}$, legs II span: $216 \mathrm{~mm}$ ). Copulatory organ of female similar to that of $H$. kusi sp.n. in having similar median margins of lateral lobes and no subseptal pocket, but may be distinguished by the following combination of characters (Figs 106-110): 1. internal duct system with glandular parts of first winding situated latero-anteriorly (centrally to posteriorly in H. kusi sp.n.), 2. posterior parts of internal duct system extending laterally very slightly beyond first winding (extending more distinctly beyond first winding and are situated more laterally in H. kusi sp.n.), 3. first winding of internal duct system rounded medially (parallel medially in $H$. kusi sp.n.), 4. median margins of lateral lobes with rounded anterior part and straight parallel posterior part (posterior diverging posteriorly in $H$. kusi sp.n.), 5. anterior bands of epigynal field distinctly longer than in $H$. kusi sp.n.

NOTE. The female was collected relatively close to the holotype of $H$. cece sp.n. Both species are considered to belong to different species groups: $H$. cece sp.n. and $H$. belua represent one group based on similarity of male palps, H. maukin sp.n. and H. kusi sp.n. represent a different group based on similarties of female copulatory organs.

DESCRIPTION. Female. Prosoma length 16.7, width 14.3, anterior width 8.0, opisthosoma length 16.3, width 8.8. Eyes: AME 0.60, ALE 0.98, PME 0.76, PLE 0.95, AME-AME 0.29, AME-ALE 0.10, PMEPME 0.51, PME-PLE 0.81, AME-PME 0.65, ALEPLE 0.79, clypeus height at AME 1.92, at ALE 1.59. Spination: palp: 131, 101, 2121, 1014; legs: femur IIII 323, IV 331; patella I-IV 101; tibia I-II 2026, IIIIV 2126; metatarsus I-II 1014, III 2014, IV 3036. 


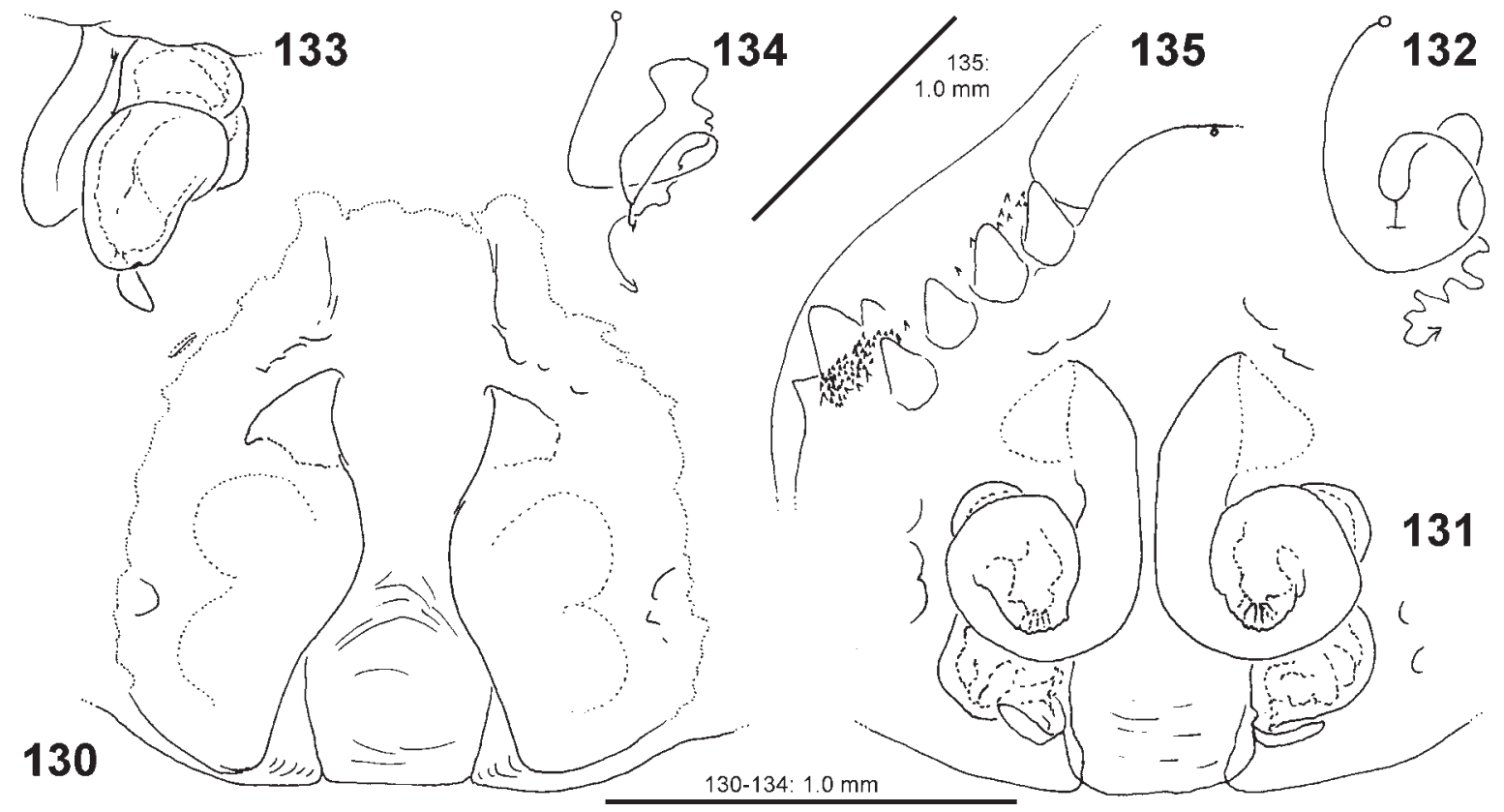

Figs 130-135. Heteropoda strasseni, 9 holotype from Java. 130 — epigyne, ventral; 131, 133 — internal duct system (131 — dorsal; 133 - frontal); 132, 143 - schematic course of internal duct system (132 — dorsal; 134 - frontal). 135 - chelicerae, ventral.

Рис. 130-135. Heteropoda strasseni, голотип (+) из Явы. 130 - эпигина, вентрально; 131, 133 - внутренняя система трубок (131 - сверху; 133 - спереди); 132, 143 - схема канальцев эндогины (132 — сверху; 134 - спереди). 135 - хелицера, вентрально.

Ventral metatarsus IV with many bristles along entire length, in distal half embedded in scopula, ventral metatarsus III only few bristles in proximal patch. Leg formula: 2143. Measurements of palp and legs: palp $20.2(9.5$, $4.3,7.1,-, 9.3)$, leg I $91.3(24.2,9.2,27.6,25.2,5.1)$, leg II $97.3(27.2,9.6,29.5,25.8,5.2)$, leg III 80.7 (23.0, 8.4, 24.1, 20.7, 4.5), leg IV 90.2 (25.5, 8.0, 26.1, 25.9, 4.7). Cheliceral furrow with 65 denticles situated in one patch close to the three promarginal teeth and additional 0-2 distal denticles. Promargin of chelicerae with 3 teeth, retromargin with 4 teeth on right side, and additional median tooth on left side. Palpal claw with 10 teeth and 1 small tooth (Fig. 111). Left leg I prolateral claw with 14 teeth, primary tooth not prominent, may be due to abrasion (Fig. 112; see also H. opo sp.n. in this paper).

Copulatory organ as in diagnosis (Figs 106-110). Epigynal field as long as wide, with long anterior bands, attached to field; with 2 slit sensilla separated by $1-2.5$ times their width from the field. Median septum partly visible, partly covered by lateral lobes, without subseptal pocket. Lateral lobes almost touching each other at a point medially. Internal duct system with glandular pores latero-anteriad. Fertilisation ducts separated by one width of posterior part of internal duct system.

Colouration (Figs 115-117): reddish brown with indistinct darker pattern. Dorsal shield of prosoma with bright transversal band behind posterior eye row, a bright V-shaped pattern along border between head and thorax parts and typical submarginal transversal band posteriorly, the latter followed by a marginal dark band. Fovea a bit darker. Sternum and coxae ventrally pale reddish brown, without pattern; labium and gnathocoxae distinctly darker reddish brown, with gnathocoxae with distal bright tips. Chelicerae dark brown. Legs with indistinct femoral spine patches. Opisthosoma dorsally brighter in anterior half; posterior half with 2 broad dark chevrons, distinctly followed by bright line (pattern similar as that in H. boiei (Doleschall, 1859). Opisthosoma laterally without distinct pattern, ventrally brighter, without pattern.

Male. Unknown.

DISTRIBUTION. Only known from the type locality (Fig. 99: open circle).

Heteropoda kusi sp.n.

Figs 99, 118-129, 136-141.

TYPE MATERIAL. INDONESIA, BORNEO: Holotype $\sigma^{7}$ (PJ 3130) and paratypes 1 \% (PJ 3131), 1 क (PJ 3132), South Kalimantan, Province Pagat, ca. 6 km E of Barabai, Gunung Batu Benawa, Gua Hadangan, S $2^{\circ} 28^{\prime} 40^{\prime \prime}$, E $115^{\circ} 24^{\prime} 46^{\prime \prime}, 130 \mathrm{~m}$, limestone cave, dark zone, P. Schwendinger, 14.10.2008, IND 08-20 (MHNG, PJ 3131 SMF).

ETYMOLOGY. The species name is derived from the German adjective „KUrzSIchtig“, meaning "shortsighted" in a figurative sense and referring to the apparent but surprising non-ability of the thinking species Homo sapiens to plan not farther in the future than one or two generations, although resources and natural treasures are obviously delimited against a steadily increasing human population; term in apposition. 


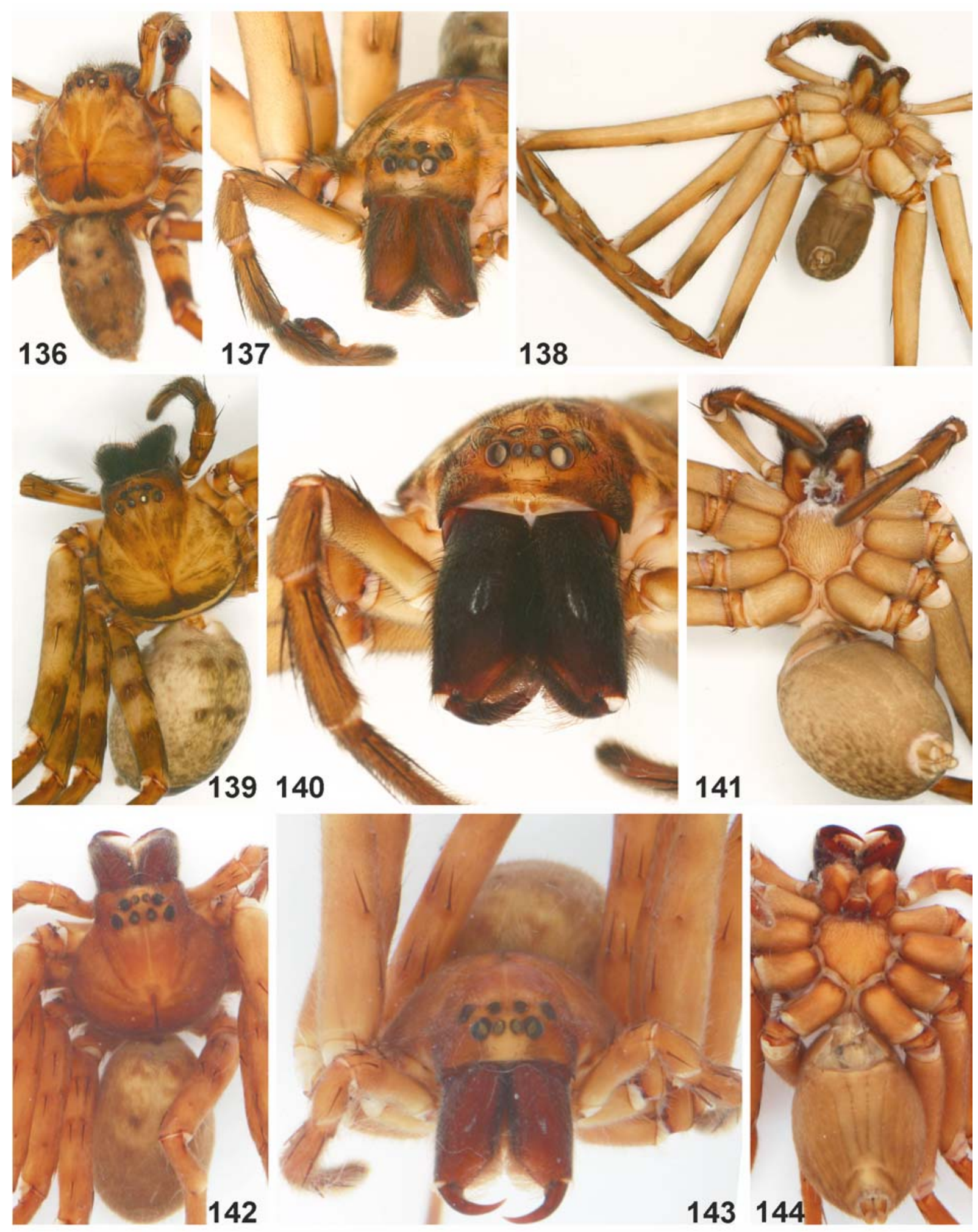

Figs 136-144: Habitus of preserved spiders. 136-141 - Heteropoda kusi sp.n. from Kalimantan (136-138 - o holotype; 139-141 -

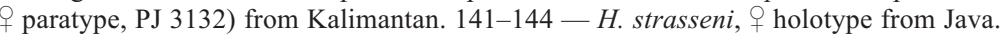

Рис. 136-144: Габитус фиксированных spiders. 136-141 — Heteropoda kusi sp.n. из Калимантана (136-138 — голотип О’' 139141 — паратип + , РЈ 3132) из Калимантана. 141-144 — H. strasseni Strand, 1915, голотип + из Явы. 


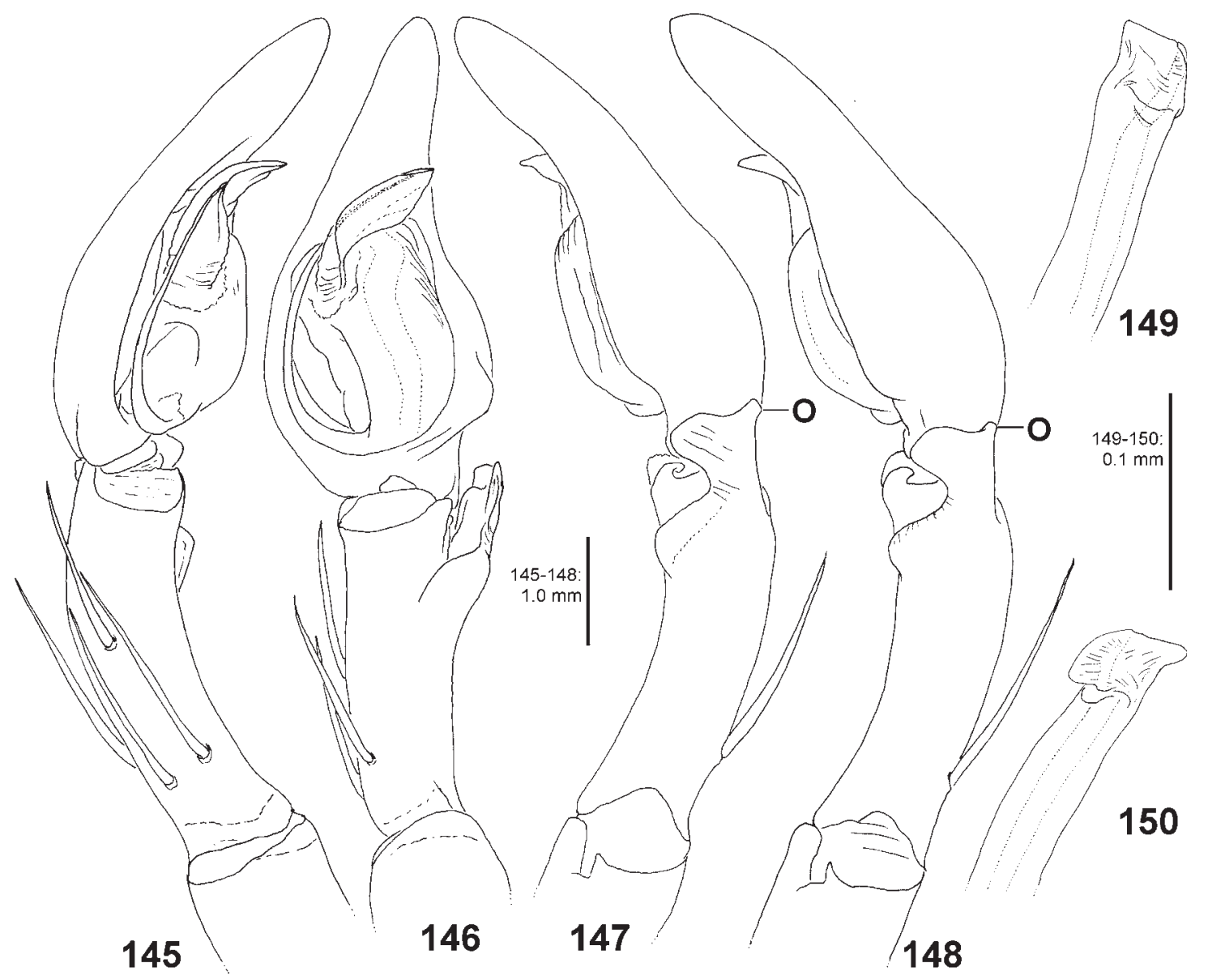

Figs 145-150. Heteropoda obe sp.n. from Sulawesi, male copulatory organs, holotype (145-147), paratypes (148 - PJ 3257; 149150 - PJ 3140); Left palp (145 — prolateral; 146 - ventral; 147-148 - retrolateral; 149-150 - tip of embolus, distal). O - distal outgrowth of RTA.

Рис. 145-150. Heteropoda obe sp.n. из Сулавеси, пальпа самца, голотип (145-147), паратипы (148 - РJ 3257; 149-150 - РJ 3140); Левая пальпа (145 — пролатерально; 146 — вентрально; 147-148 — ретролатерально; 149-150 — кончик эмболюса, дистально). O - дистальный вырост RTA.

DIAGNOSIS. Large sized (body length of $\sigma^{7}: 20.9$ 22.7, of 9 : 28.3). Males may be recognized by the following combination of characters (Figs 118-123): 1. dRTA strongly developed, widening and rounded distally in retrolateral view (similar to that of $H$. obe sp.n., but with a more strongly pronounced rounded part and without distinct dorsal apex); 2. tibia slender (i.e., 3.5 times as long as basally wide in retrolateral view); 3. embolus arising from tegulum in 5-o'clockposition, running proximad, then semi-circular, its tip with simple opening, without any modification. Female copulatory organs similar to those of $H$. strasseni Strand, 1915 in having median septum without subseptal pocket and similar course of the internal duct system, but may be distinguished by the following combination of characters (Figs 124-129): 1. generally larger with $28.3 \mathrm{~mm}$ body length (18.1 $\mathrm{mm}$ in H. strasseni); 2 . median parts of first winding of internal duct system transparent and running almost parallel, only in very anterior part diverging (opaque and diverging more strongly in H. strasseni); 3. glandular pores laterad to anterio-laterad (posteriad in $H$. strasseni); 4. anterior bands of epigynal field narrow and moderately long (short in H. strasseni). 5. chelicerae with basal patch of denticles (with additional distal patch in H. strasseni).

DESCRIPTION. Male (holotype). Prosoma length 10.7, width 9.5 , anterior width 4.6, opisthosoma length 10.2, width 5.6. Eyes: AME 0.53, ALE 0.73, PME 0.57, PLE 0.76, AME-AME 0.18, AME-ALE 0.06, PME-PME 0.35, PME-PLE 0.57, AME-PME 0.60, ALE-PLE 0.58, clypeus height at AME 1.14, at ALE 0.82. Spination: palp: 131, 101, 2121, 001(2)0; legs: femur I-III 323, IV 332(1); patella 101; tibia I-IV 2226; metatarsus I-II 1014, III 2014, IV 3036. Metatarsus IV ventrally with many bristles along its entire length, distally more dense, metatarsus III with some bristles in proximal half. Leg formula: 2143. Measurements of palp and legs: palp 19.1 (6.5, 2.7, 4.2, -, 5.7), leg I $71.9(19.8,6.2,22.5,19.6,4.8)$, leg II 84.7 (22.0, 6.7, 26.1, 24.9, 5.0), leg III $64.0(17.7,5.6,19.7,17.4$, 


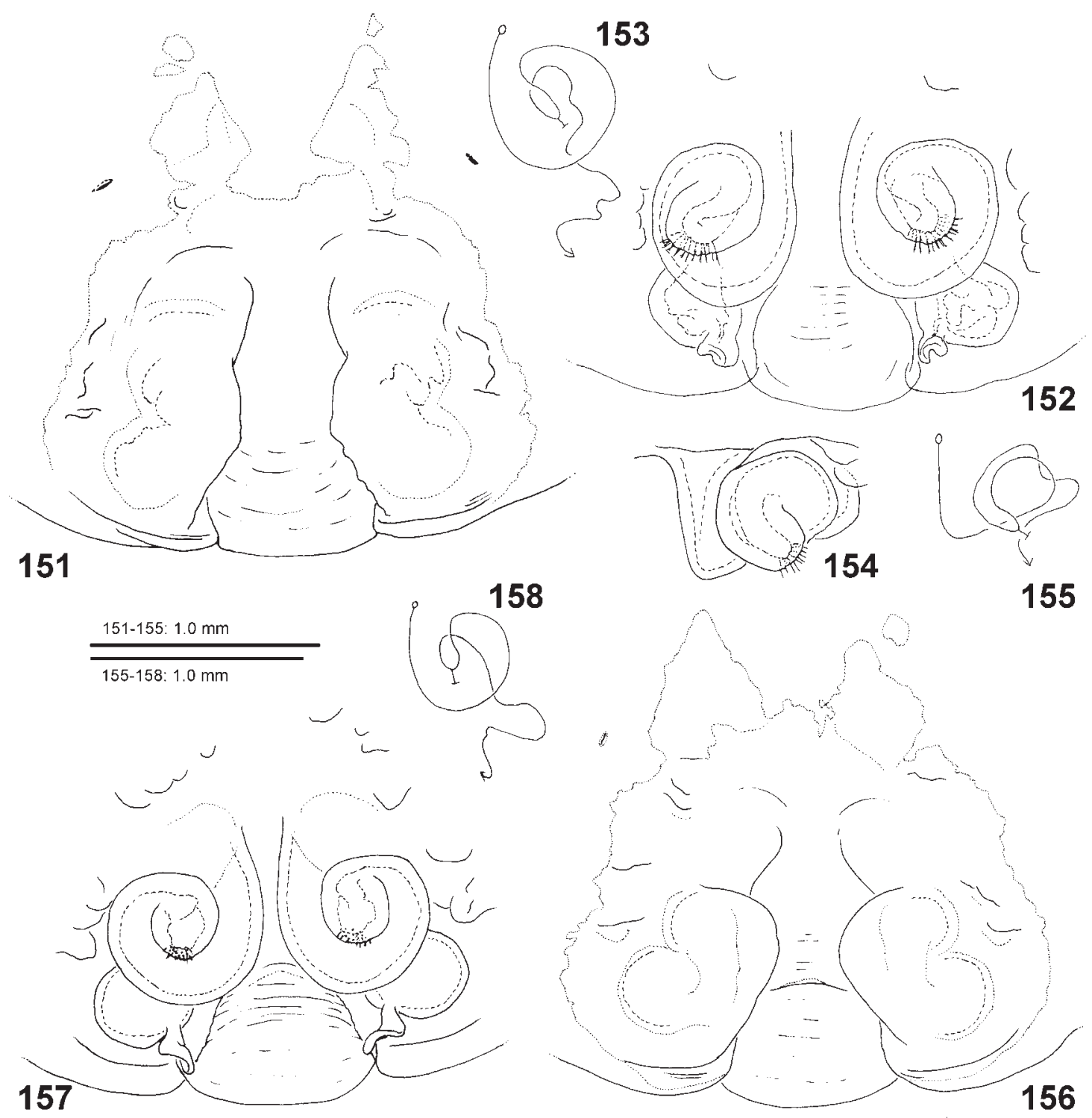

Figs 151-158. Heteropoda obe sp.n. from Sulawesi, female copulatory organs, paratypes (151-155 - PJ 3157; 156-158 — PJ 3258). 151,156 - epigyne, ventral; $152,154,157$ - internal duct system $(152,157$ - dorsal; 154 - frontal); 153, 155, 158 - schematic course of internal duct system $(153,158$ - dorsal; 155 - frontal).

Рис. 151-158. Heteropoda obe sp.n. из Сулавеси, паратипы (151-155 - РЈ 3157; 156-158 - PJ 3258). 151, 156 - эпигина, вентрально; 152, 154, 157 - эндогина $(152,157$ — сверху; 154 — спереди); 153, 155, 158 - схема канальцев эндогины $(153,158$ сверху; 155 - спереди).

3.6), leg IV $69.1(18.7,5.3,20.6,20.3,4.2)$. Cheliceral furrow with about 60 denticles situated in one patch close to the three promarginal teeth (Fig. 129). Promargin of chelicerae with 3 teeth, retromargin with 4 teeth.

Male palp as in diagnosis (118-123). RTA arising distally on tibia, dRTA with tiny dorsal hump or tooth basally. Conductor slender, distinctly pointed, arising in a 10:30-o'clock-position on tegulum. Spermophor running almost straight diagonally with small loop in basal embolus.

Colouration (Figs 136-138): generally yellowishto reddish-brown with darker brown pattern. Prosoma posteriorly with bright submarginal transversal band and dark marginal band, in front with dark patch at posterior fovea and indistinct radial pattern. Sternum, gnathocoxae and coxae ventrally yellowish-brown, without pattern, labium and inner parts of gnathocoxae reddish-brown. Chelicerae dark reddish-brown with dark-brown longitudinal striae. Legs yellowish-brown on femora becoming darker, i.e. reddish-brown distally; femora with spine patches and distal part darker, femora II with short dorsal stripe proximally, tibiae with indistinct spine patches. Opisthosoma with irregular pattern dorsally with muscle sigilla marked and 
indistinct transversal band in posterior half. Opisthosoma ventrally without distinct pattern; anterior of epigastric furrow yellowish-brown, posterior of it darker with converging lines of tiny muscle sigilla medially.

Female. Prosoma length 12.4, width 10.7, anterior width 6.1, opisthosoma length 15.9, width 10.0. Eyes: AME 0.51, ALE 0.80, PME 0.62, PLE 0.85, AMEAME 0.27, AME-ALE 0.10, PME-PME 0.40, PMEPLE 0.69, AME-PME 0.61, ALE-PLE 0.61, clypeus height at AME 1.33, at ALE 0.98. Spination: palp: 131, 101, 2121, 1014; legs: femur I-III 323, IV 331(2); patella 101; tibia I-II 2026, III-IV 2026; metatarsus III 1014, III 2014, IV 3036. Ventral metatarsus III and IV as in male. Leg formula: 2143. Measurements of palp and legs: palp $21.5(6.4,3.0,5.3,-, 6.8)$, leg I $63.5(17.0,6.7,19.4,16.7,3.7)$, leg II $68.9(18.9,7.0$, $21.1,17.8,4.1)$, leg III $56.7(16.3,5.8,17.0,14.1,3.5)$, leg IV $61.9(17.7,5.7,17.9,17.5,4.1)$. Cheliceral furrow with about 60 denticles situated in one patch close to the three promarginal teeth. Promargin of chelicerae with 3 teeth, retromargin with 4 teeth. Palpal claw with 8 teeth.

Copulatory organ as in diagnosis (Figs 124-128). Epigynal field trapezoid, as wide as long. Three slit sensilla close to epigynal field, i.e. separated from field roughly by their lengths. Lateral lobes with large shallow cavities, opened to median septum and possibly accommodating enlarged dRTA. First winding of internal duct system with 1.5 loops by glandular pores, its median part membranous. Ducts close to glandular pores situated at posterior margin of first winding. Ducts functionally behind glandular pores, i.e. situated ventrally, distinctly sinuous (ventral view).

Colouration (Figs 139-141): as in male, but with following differences: dark transversal band anterior of bright band in posterior half of dorsal shield of prosoma; femora with larger, partly fused spine patches and several dots between patches; chelicerae darker, longitudinal bands barely recognisable.

VARIATION. Male paratype: prosoma length 10.4, width 9.4 anterior width 4.7, opisthosoma length 12.3 , width 6.3. Spination: both palpal cymbia with 0010 , both femora IV 331, patella IV 101(0), tibia IV 22(1)26. Colouration: dorsal shield of prosoma with dark transversal band in front of bright band in posterior half. Opisthosoma ventrally posterior of epigastric furrow bright as in anterior part, with four lines of tiny muscle sigilla visible.

DISTRIBUTION. Only known from the type locality (Fig. 99: open square).

\section{Heteropoda strasseni Strand, 1915 Figs 130-135, 141-144.}

Heteropoda strasseni Strand, 1915: 245 (description of holotype 9 , PJ 234, Indonesia, E Java, E. Hasselt leg., SMF 4583, examined).

DIAGNOSIS. See diagnosis of $H$. kusi sp.n.

REDESCRIPTION. Female (holotype). Prosoma length 7.8, width 7.3, anterior width 4.1, opisthosoma length 9.4, width 6.1. Eyes: AME 0.41, ALE 0.60,
PME 0.50, PLE 0.64, AME-AME 0.26, AME-ALE 0.10, PME-PME 0.37, PME-PLE 0.60, AME-PME 0.46, ALE-PLE 0.57, clypeus height at AME 0.68, at ALE 0.53. Spination: palp: 131, 101, 2121, 1014; legs: femur I-III 323, IV 331; patella I-IV 001; tibia I-III 2026, IV 2126; metatarsus I-II 1014, III 2014, IV 3036. Ventral metatarsus IV with many bristles along almost entire length, distally with numerous bristles, ventral metatarsus I-III with scopulae. Measurements of legs II: 37.3 (10.3, 4.5, 11.1, 8.9, 2.5). Cheliceral furrow with ca. 65 denticles situated in basal patch and smaller elongated distal patch. Promargin of chelicerae with 3 teeth, retromargin with 4 teeth. Palpal claw with 6 teeth.

Copulatory organ as in diagnosis of $H$. kusi sp.n. Epigynal field as long as wide with short anterior bands integrated in the field. One slit sensillum close to epigynal field. Internal duct system with anterior part as wide as posterior part. Fertilisation ducts separated by more than one width of posterior part of internal duct system.

Colouration: brown to reddish-brown. Dorsal shield of prosoma with striae and marked fovea; posterior margin with indistinct bright and dark transversal band. Ventral coxae, sternum and gnathocoxae without pattern. Chelicerae dark reddish-brown, with indistinct darker longitudinal bands. Femora with indistinct spine patches. Opisthosoma dorsally with muscle sigilla darker, in posterior half with indistinct short transversal line. Opisthosoma ventrally lighter medially, with two external and two inner lines consisting of tiny muscle sigilla. External parts of lateral spinnerets dark.

Male. Unknown.

DISTRIBUTION. Known only from the type locality E Java (no detailed locality known, therefore not mapped).

\section{Heteropoda obe sp.n.} Figs 100, 145-169.

TYPE MATERIAL. INDONESIA: Holotype $\sigma^{7}$ (PJ 3155), N Sulawesi, Manado [ $1^{\circ} 29^{\prime} 10.24^{\prime \prime} \mathrm{N}, 124^{\circ} 51^{\prime} 16.65^{\prime \prime} \mathrm{E}, 40 \mathrm{~m}$ ], artificial cave made by Japanese in $2^{\text {nd }}$ world war, J.M. Verdez \& C. Bauduin, 14.11.2007 (SMF). Paratypes (all with same data as for holotype): $10^{7}$ (PJ 3156), 1 + (PJ 3157) (SMF), $10^{7}$ (PJ 3257), 1 ㅇ (PJ 3258) (SMF), 1 O $^{7}$ (PJ 3167), (MHNG), 1 O (PJ 3168), (NHM), $1 \sigma^{7}$ (PJ 3169), (MNHN), 1 (PJ 3142), SD 606 (MHNG), $1 \sigma^{7}$ (PJ 3141), SD 605 (AMNH), 1 ơ (PJ 3140), SD 604 (RMNH).

ETYMOLOGY. The species name is derived from the Danish and Norwegian word "OverBEfolkningen" meaning "overpopulation" and stressing the negative impact of the human overpopulation on natural habitats and biological diversity; term in apposition.

DIAGNOSIS. Large (body length of $\sigma^{7}:$ 18.0-22.6, of : : 24.0-27.0) similar to H. kusi sp.n. in respect of copulatory organs in both sexes, of colouration, and of body length. Males can be distinguished by the following combination of characters (Figs 145-150): 1. dRTA with distinct disto-dorsal outgrowth, 2 . embolus thicker, arising in a 6-o'clock-position and with characteristic modification at its distal end, 3 . conductor distinctly 

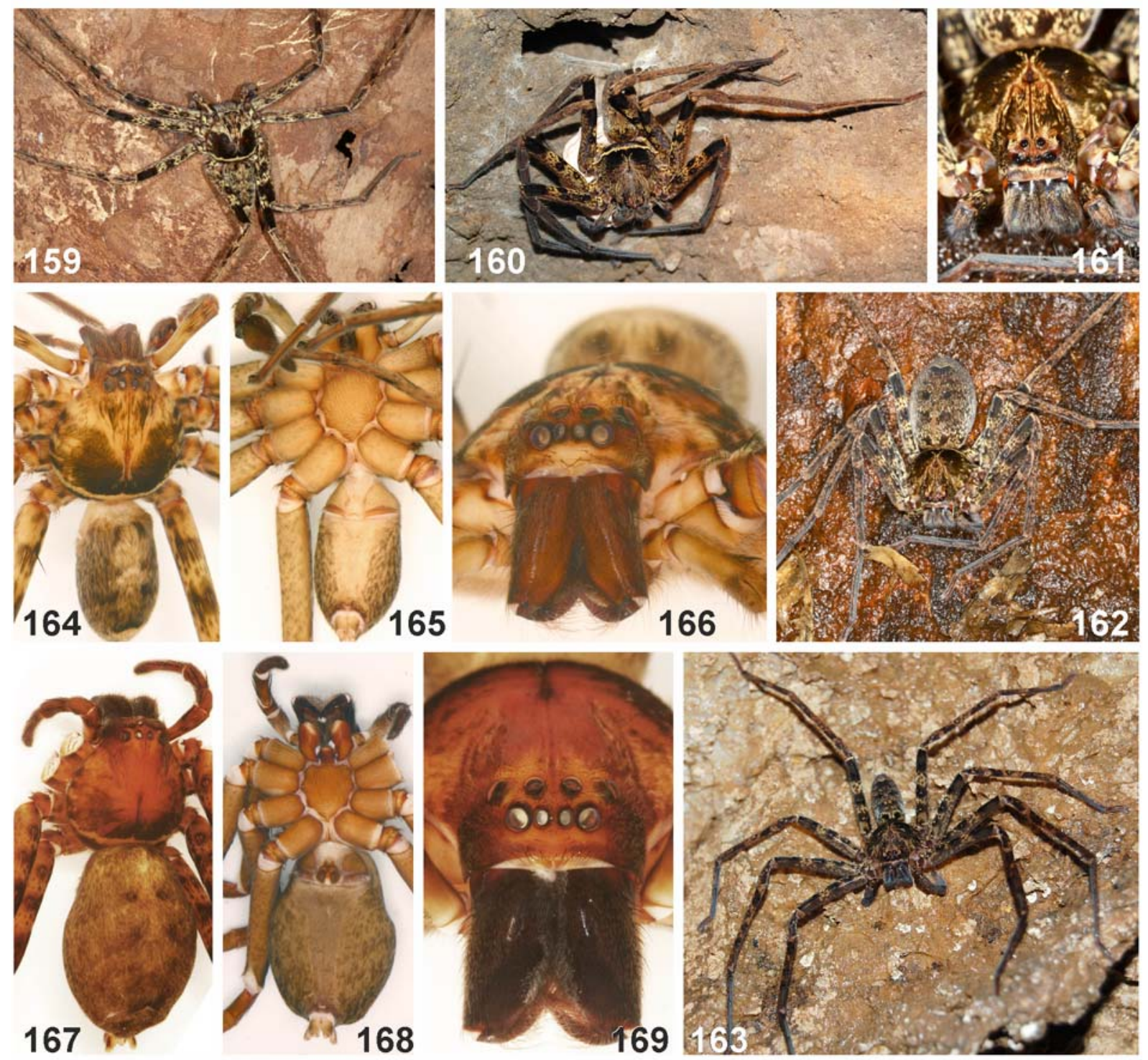

Figs 159-169. Heteropoda obe sp.n. from Sulawesi, habitus of live (159-163) and preserved spiders (164-165 — O holotype; 166 o' paratype, PJ 3169; 167-169 - + paratype, PJ 3157). 159-163 — by courtesy of Jean Michel Verdez.

Рис. 159-169. Heteropoda obe sp.n. из Сулавеси, габитус живих (159-163) и фиксированных пауков (164-165 - голотип о; 166 — паратип O’, PJ 3169; 167-169 — паратип +, PJ 3157). 159-163 — с разрешения Jean Michel Verdez.

stouter, i.e. shorter and broader, 4. palpal tibia and cymbium stouter (tibia less than 3 times as long as its basal width). Females may be recognised by the following combination of characters (Figs 151-158): 1. visible part of median septum broader, 2. median part of first winding of internal duct system shorter and anteriorly not distinctly bent, 3. glandular pores of internal duct system posteriad to posterio-laterad, glandular part situated centrally in first winding.

DESCRIPTION. Male (holotype). Prosoma length 9.4, width 8.9, anterior width 4.0, opisthosoma length 9.5, width 5.4. Eyes: AME 0.50, ALE 0.72, PME 0.57, PLE 0.71, AME-AME 0.22, AME-ALE 0.03, PME-PME 0.39, PME-PLE 0.43, AME-PME 0.50, ALE-PLE 0.52, clypeus height at AME 0.68, at ALE 0.51. Spination: palp: 131, 101, 2101; legs: femur I-II 323, III 333, IV 331; patella 101; tibia I-III 2226, IV 2126; metatarsus I-II 1014, III 2014, IV 3036. Metatarsus IV ventrally with many bristles along its entire length and sparse scopula, metatarsus III with several bristles in proximal two thirds. Leg formula: 2143. Measurements of palp and legs: palp $15.8(5.2,2.2,3.8,-, 4.6)$, leg I 56.7 $(14.7,5.2,16.5,15.8,4.5)$, leg II $62.8(16.3,5.5,18.6$, $17.7,4.7)$, leg III $46.7(12.9,4.5,13.3,12.5,3.5)$, leg IV $52.9(14.2,4.3,14.7,15.7,4.0)$. Cheliceral furrow with ca. 65 denticles situated in one patch close to the three promarginal teeth and 9-10 distal denticles. Promargin of chelicerae with 3 teeth, retromargin with 4 teeth. 


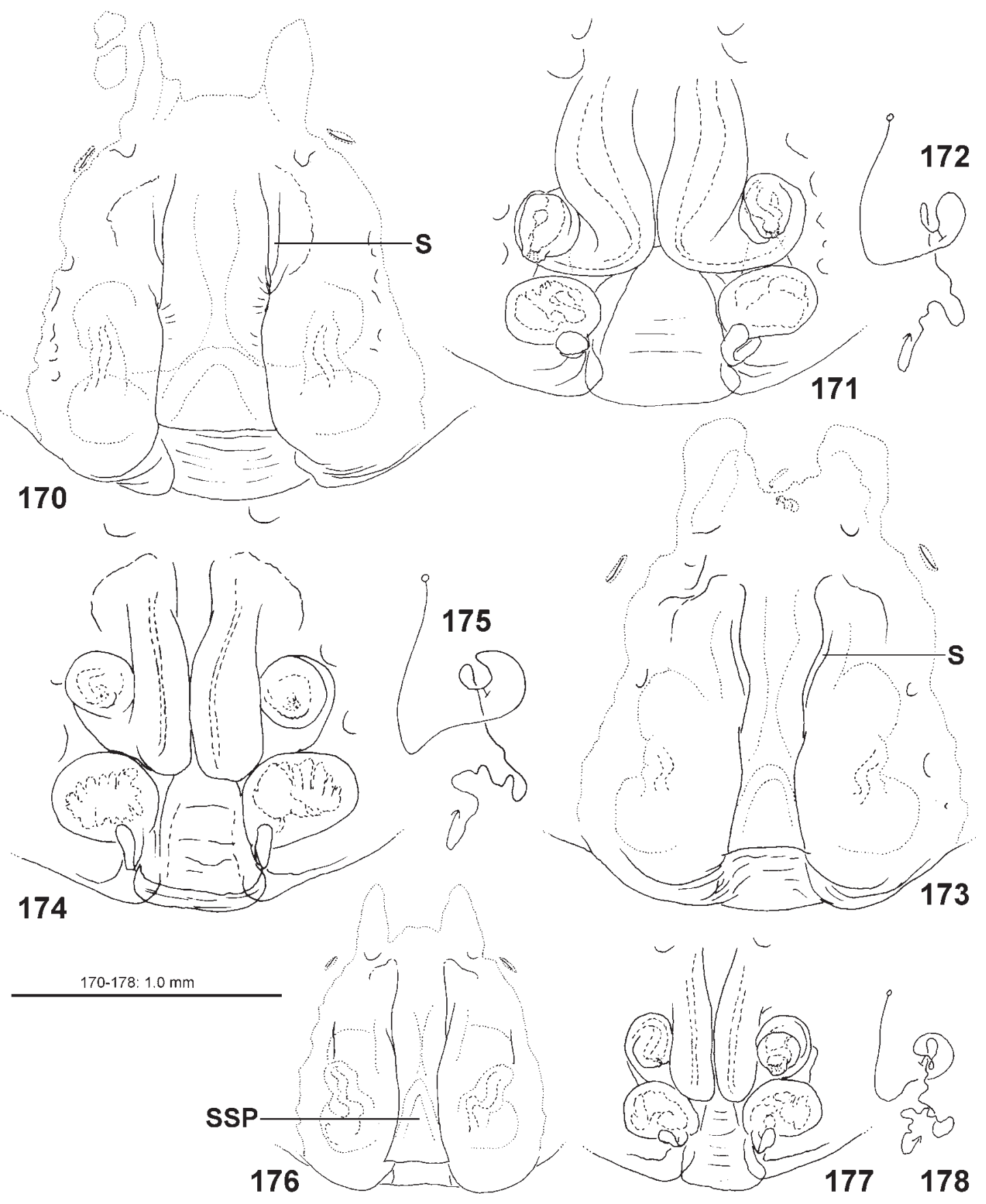

Figs 170-178. Heteropoda nigriventer from Sulawesi, female copulatory organs (170-172 - PJ 3195; 173-175 - PJ 3197; 176-178 PJ 3200). 170, 173, 176 - epigyne, ventral; 171, 174, 177 - internal duct system, dorsal; 172, 175, 178 - schematic course of internal duct system, dorsal. S — slits beside median septum; SSP — subseptal pocket.

Рис. 170-178. Heteropoda nigriventer из Сулавеси (170-172 — РЈ 3195; 173-175 — РJ 3197; 176-178 — РЈ 3200). 170, 173, 176 эпигина, вентрально; 171, 174, 177 — эндогина, сверху; 172, 175, 178 — схема канальцев эндогины, сверху. S — щели по бокам от септума; SSP - карман под септумом.

Male palp as in diagnosis (Figs 145-150). With RTA arising distally on tibia, dRTA massive, bilobate. Cymbium with distinct retrolateral lobe in proximal half. Conductor arising in 10:30-o'clock-position on tegulum. Embolus semi-circular, its tip with subdistal opening of spermophor and small distal outgrowth.
Colouration (Figs 164-166): generally yellowishbrown with darker brown pattern mostly consisting of dark hairs. Dorsal shield of prosoma with dark bilobate patch in posterior half, bright submarginal transversal, and dark marginal band at posterior margin. Fovea slightly marked anteriorly, with irregular pattern be- 

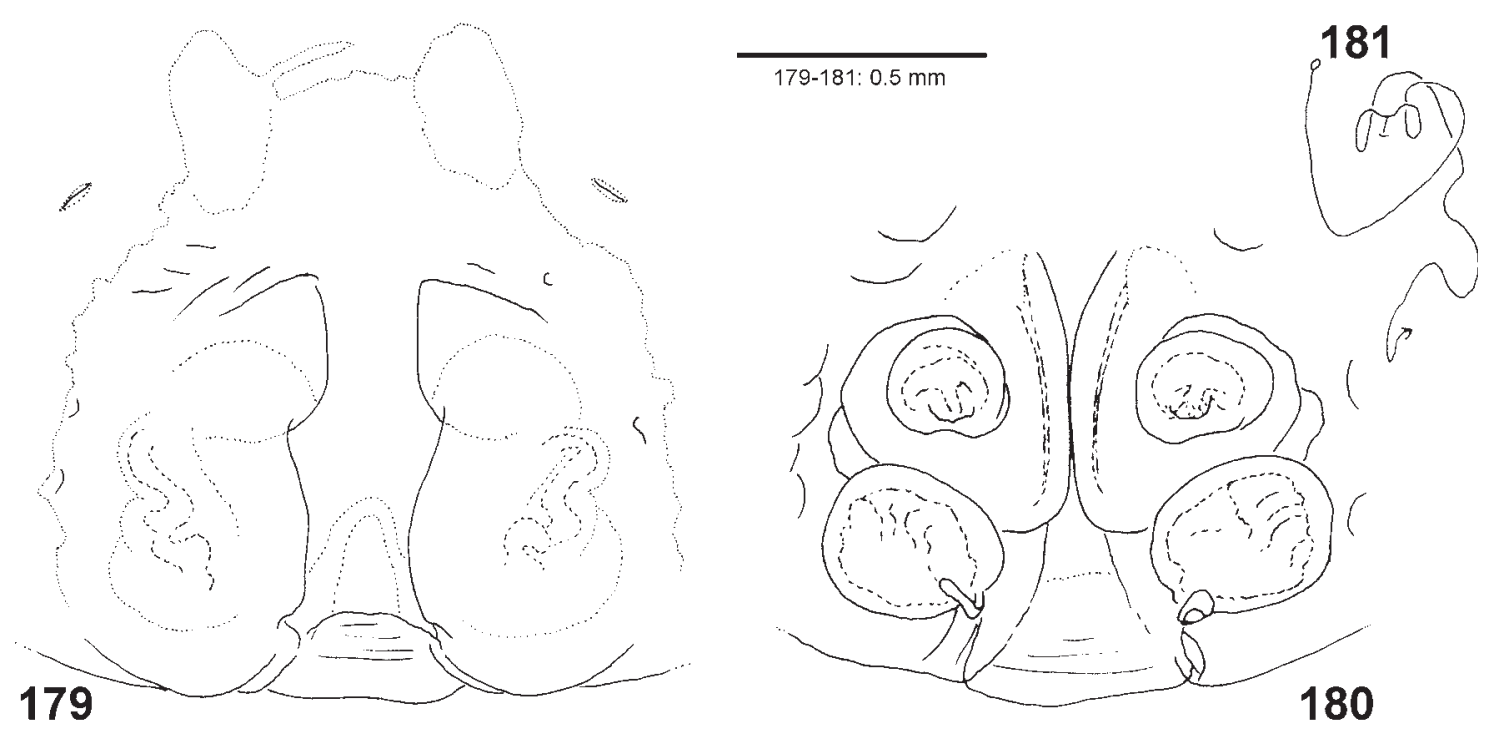

Figs 179-181. Heteropoda kabaenae from Sulawesi, + holotype, copulatory organs. 179 — epigyne, ventral; 180 - internal duct system, dorsal; 181 - schematic course of internal duct system, dorsal.

Рис. 179-181. Heteropoda kabaenae из Сулавеси, голотип +. 179 - эпигина, вентрально; 180 - эндогина, сверху; 181 схема канальцев эндогины, сверху.

hind eyes. Sternum, labium, gnathocoxae and ventral coxae pale yellowish-brown, without pattern. Chelicerae reddish-brown with longitudinal bands frontally. Femora with spine patches in their proximal two third, partly fused and with distinct dots and proximal median lines between patches, ventral femora with numerous small spots; distal femora dark; patellae dark with bright prolateral spot proximally; tibiae with irregular pattern. Opisthosoma dorsally with two small dark patches at anterior margin, bright patch above heart, muscle sigilla marked darkly, dark transversal patch in posterior half and bright patch behind the latter; opisthosoma laterally spotted; opisthosoma ventrally pale yellowish-brown with almost no pattern. For colouration of live spider see Fig. 159.

Female (paratype, PJ 3157). Prosoma length 10.7, width 10.1, anterior width 5.3, opisthosoma length 16.3, width 11.0. Eyes: AME 0.56, ALE 0.75, PME 0.54, PLE 0.78, AME-AME 0.25, AME-ALE 0.09, PMEPME 0.50, PME-PLE 0.70, AME-PME 0.59, ALEPLE 0.62, clypeus height at AME 0.90, at ALE 0.75. Spination: palp: 131, 101, 2121, 1014; legs: femur IIII 323, IV 331; patella 101 (all patellar spines distinctly smaller than in male); tibia I-III 2026, IV 2126; metatarsus I-II 1014, III 2014, IV 3036. Ventral metatarsus IV with many bristles along its entire length and sparse scopula, metatarsus III with few bristles in proximal part. Leg formula: 2143. Measurements of palp and legs: palp $27.1(5.2,2.5,3.9,-, 5.5)$, leg I 48.5 (13.1, 5.7, 14.1, 12.0, 3.6), leg II 50.6 (15.0, 5.8, 16.0, $13.1,3.7)$, leg III $41.9(12.5,4.7,12.4,10.4,2.9)$, leg IV $48.2(13.5,4.4,13.3,13.4,3.6)$. Cheliceral furrow with ca. 80 denticles situated in one patch close to the three promarginal teeth and 13-14 distal denticles. Pro- margin of chelicerae with 3 teeth, retromargin with 4 teeth. Palpal claw with 9 teeth.

Copulatory organ as in diagnosis (Figs 151-158). Epigynal field trapezoid, wider than long, with subtriangular anterior bands. Two slit sensilla separated from field by 2-3 times their lengths. Lateral lobes with large shallow cavities, opened to median septum and possibly accommodating enlarged dRTA. First winding of internal duct system with less than 1.5 loops by glandular pores.

Colouration (Figs 167-169): as in male, but generally darker, i.e. more reddish-brown and with less distinct pattern, especially on legs. Dark patch on posterior prosoma not as distinctly bilobate as in male, colour pattern posterior of eyes absent. Patellae without distinct pattern, bright prolateral patch indistinct or absent. Opisthosoma dorsally without distinct bright patch above heart and behind dark transversal patch in posterior half. For colouration of live spiders see Figs 160163.

VARIATION. Males: prosoma length 8.7-10.7, opisthosoma length 8.8-12.0. Females: prosoma length 12.5, opisthosoma length 11.8; one female (PJ 3142) with tibia IV 2026. Paratype $\sigma^{7}$ (PJ 3257) with distal outgrowth on the RTA slightly smaller and the cymbium slightly longer (Fig. 148). Paratype + (PJ 3258) with pores of the internal duct system posteriad and the glandular part relatively smaller. Inner margins of the lateral lobes in this paratype distinctly rounded, and with only one slit sensillum on the right side of the epigynal field (Figs 156-158).

DISTRIBUTION. The species is known from various caves around Manado (Verdez, personal communication) (Fig. 100: diamond). 


\section{Heteropoda nigriventer Pocock, 1897}

Figs 100, 170-178, 194-196.

Heteropoda nigriventer Pocock, 1897: 617, pl. 26, f. 20 (description of holotype + , PJ 1763, Indonesia, Sulawesi, Donggala [ca. $0^{\circ} 40^{\prime} 44.52^{\prime \prime} \mathrm{S}, 119^{\circ} 44^{\prime} 51.27^{\prime \prime} \mathrm{E}, 80 \mathrm{~m}$ ], W. Kükenthal leg., NHM 97.11.1.122, examined). Jäger, 2005: 107, f. 82-84).

Heteropoda laurae Jäger, 2008b: 289, f. 320-326, 405-406 (description of holotype $\sigma^{\prime}$, PJ 2766, Indonesia, Sulawesi, Dumoga-Bone National Park [0³5'51.49”N, $\left.123^{\circ} 59^{\prime} 54.78^{\prime \prime} \mathrm{E}\right]$, 'Edward's Camp'. Lowland Forest, $664 \mathrm{~m}$, night catch in sub-camp Edwards, R. Bosmans \& J. van Stalle 4.11.1985, Cel079, IRSN, examined). Syn.n.

ADDITIONAL MATERIAL EXAMINED: INDONESIA, SULAWESI: $1 \sigma^{7}$ (PJ 3194), 1 subadult + (PJ 3199), Tompibugis, $1^{\circ} 37.524^{\prime} \mathrm{S}, 120^{\circ} 2.039^{\prime} \mathrm{E}, 400 \mathrm{~m}$, branch trap on Theobroma cacao, 5/9.2007, Stenchly leg., sampID U449P16BT21 (SMF, MZB) 4 ㅇ (PJ 3195, 3197, 3200, 3202), 1 subadult $\sigma^{\top}$ (PJ 3201), Palu, Marena $\left[1^{\circ} 34^{\prime} \mathrm{S}, 120^{\circ} 0.2^{\prime} \mathrm{E}, 975 \mathrm{~m}\right]$, branch trap on Theobroma cacao, 4.2007-1.2008, Stenchly leg. (SMF, MZB). 1 q (PJ 3197), Bolapapu, $1^{\circ} 26.105^{\prime} \mathrm{S}, 119^{\circ} 59.552^{\prime} \mathrm{E}, 650 \mathrm{~m}$, branch trap on Theobroma cacao, 9.2007, Stenchly leg., sampID U443P2BT17 (SMF) 1 subadult $O^{7}$ (PJ 3198), same data as preceding specimen, 7.2007, sampID U457P2BT20 (MZB). 1 (PJ 3203), Mataue, $1^{\circ} 26.77^{\prime} \mathrm{S}$ $119^{\circ} 59.748^{\prime} \mathrm{E}, 675 \mathrm{~m}$, branch trap on Theobroma cacao, 7.2007, Stenchly leg., sampID U454P4BT34 (BZMJ). 1 q (PJ 346), Takalekadjo mountains $\left[2^{\circ} 4^{\prime} 10.22^{\prime \prime} \mathrm{S}, 120^{\circ} 38^{\prime} 31.56^{\prime \prime} \mathrm{E}, 520 \mathrm{~m}\right]$, P. \& F Sarasin \& don. 1895 (NHMB 898.a). 1 \% (PJ 350), Kangkakulu valley, P. \& F. Sarasin don., sub "Heteropoda venatoria flavocephala Merian, 1911" on file card, sub "Heteropoda nigropuncta Pocock" [manuscript name only? Taxon name not found in Platnick 2013] on label (NHMB 550.IV.c).

NOTE. Pocock [1897] described H. nigriventer from one female collected in Donggala, Central Sulawesi. Jäger [2008b] described H. laurae from one male from Dumoga Bone National Park, North Sulawesi. The series of conspecific male and females collected in 2007 and 2008 by Kathrin Stenchly suggested that both species names are synonymous. After careful examining it was clear that all specimens in question were conspecific, although females showed quite strong variation in their copulatory organs. Therefore $H$. laurae is proposed as junior synonym of $H$. nigriventer. In the course of the present revision additional material from Basel museum collections were recognised as belonging to $H$. nigriventer.

DIAGNOSIS. For males see Jäger [2008b: 289]. Females: medium sized to large (body length: 14.229.2), may be recognised by the following combination of characters (Figs 170-178): 1. median septum of epigyne freely visible, with slits beside its anterior part and distinct subseptal pocket, 2 . internal duct system with first parallel part of first winding broad and slightly bent, 3. posterior part of internal duct system not extending or extending only slightly laterally beyond the anterior part. Additionally to characters of the copulatory organs both sexes seem to be diagnosable by two colouration features: dark eye region and dorsal median lines on femora (Fig. 194).

DESCRIPTION. Male. See Jäger [2008b: sub $H$. laurae].

REDESCRIPTION. Female (PJ 3195). Prosoma length 9.3 , width 8.5 , anterior width 4.8, opisthosoma length 11.1, width 6.6. Eyes: AME 0.48, ALE 0.71, PME 0.50, PLE 0.69, AME-AME 0.30, AME-ALE
0.09, PME-PME 0.39, PME-PLE 0.70, AME-PME 0.53 , ALE-PLE 0.65 , clypeus height at AME 0.93 , at ALE 0.66. Spination: palp: 131, 101(0), 2121, 1014; legs: femur I-III 323, IV 331; patella I-III 001, IV 000; tibia 2026; metatarsus I-II 1014, III 2014, IV 3036(1036). Ventral metatarsus IV with many bristles along entire length, distally with numerous bristles, ventral metatarsus III with some bristles in proximal half. Leg formula: 2143. Measurements of palp and legs: palp 14.9 (4.4, 2.2, 3.7, -, 4.6), leg I 39.8 (11.1, $4.8,11.3,9.8,2.8)$, leg II $41.8(11.9,4.7,12.1,10.2$, 2.9), leg III $33.1(9.9,3.9,9.3,7.7,2.3)$, leg IV 35.9 $(10.7,3.5,9.7,9.3,2.7)$. Cheliceral furrow with ca. 80 denticles situated in elongated patch along the entire cheliceral furrow. Promargin of chelicerae with 3 teeth, retromargin with 4 teeth, one chelicerae with one tiny additional tooth. Palpal claw with 7 teeth.

Copulatory organ as in diagnosis (Figs 170-178). Epigynal field as long as wide with short anterior bands. Two long slit sensilla separated by less of one of their length from epigynal field. Internal duct system with glandular part in external part of first winding, glandular pores posteriad. Posterior part of internal duct system touching first winding, connecting part distinctly bent ventrad. Fertilisation ducts separated by more than one width of posterior part of internal duct system.

Colouration (Figs 194-196): yellowish- to reddishbrown. Dorsal shield of prosoma with marble-like pattern and dark eye region; posterior margin with bright and dark transversal band. Sternum, gnathocoxae and coxae ventrally yellowish brown without pattern except for sternum with indistinct markings and gnathocoxae with distinct brighter inner zone, labium darker with bright distal margin. Chelicerae reddish brown, with darker longitudinal bands. Femora with indistinct and partly broken median line, spine patches with bases with short white hairs, and spots. Patellae and tibiae with indistinct pattern. Opisthosoma dorsally dark with bright lanceolate patch above heart. Opisthosoma ventrally dark, with two brighter external and two darker inner lines consisting of tiny muscle sigilla. External parts of lateral spinnerets dark.

VARIATION. Males: total body length 15.9 (holotype: 17.7). Spination: palpal tibia 2121 (holotype: 2111 as shown, e.g., in Jäger [2008b: fig. 323, incorrectly listed in text as 2101]), femur III 323(333) (holotype: 323(322)), patella III 101 (holotype: 001), tibia III 2126(2026), IV 2026 (holotype: III-IV 2126).

Females: chelicerae: $130-140$ denticles in elongated patch (PJ 3203); ca. 80 denticles in elongated patch (PJ 3195); a basal and a distal patch connected with a single line of rows (PJ 3202); basal patch with ca. 50 denticles and a single row consisting of 4-8 denticles (PJ 3200, PJ 350); basal patch with ca. 60 denticles and a single row consisting of 9 denticles (PJ 3197); basal (60-70) and distal patch (5 denticles) (PJ 346). Spination: patellae variable (I 001, II 101/001/000, III 101/001, IV 100/001/000), metatarsus III 2024. Palpal claw with 6-7 teeth, in some cases with additional small tooth. Opisthosoma ventrally with dark median 
triangular band. Immature spiders: generally brighter and with less distinct colouration pattern, median line on dorsal femora partly absent.

BIOLOGY. The present specimens were collected exclusively with branch traps in cacao plantations. Most likely this species is a foliage dweller as suggested for Heteropoda dagmarae Jäger et Vedel, 2005 [Jäger, 2007]. Phenological data: adult males are known from September and November, subadult males from January and July, adult females from April, July, August, September, December, and subadult females from May.

DISTRIBUTION. Known from North and Central Sulawesi, Indonesia (localities Kangkakulu valley and Takalekaigo not found) (Fig. 100: grey triangles).

RELATIONSHIPS. Jäger [2008b: 288] proposed four species (H. mecistopus Pocock, 1898, H. hildebrandti Jäger, 2008, H. belua Jäger, 2005, and $H$. laurae $=H$. nigriventer) to be closely related by the similar course of their spermophor, origin and course of the embolus, and partly by the presence of an embolic apophysis, a modified dRTA, and chelicerae having five teeth. The latter character could not be observed in the male holotype of $H$. laurae, instead widely spaced teeth were documented [Jäger, 2008b: 291]. In two of the females examined a tiny fifth posterior tooth supports the assumed relationship. Heteropoda nigriventer and $H$. kabaenae are closely related by means of their similar female copulatory organs and the presence of a darker eye region in combination with a median dorsal line of leg femora.

\section{Heteropoda kabaenae Strand, 1911}

Figs 100, 179-181, 197-198.

Heteropoda kabaenae Strand, 1911a: 207 (description holotype ${ }^{\circ}$, PJ 298, Indonesia, Southeast Sulawesi, Kabaena [ca. $5^{\circ} 15^{\prime}$ $\left.0.00^{\prime \prime} \mathrm{S}, 121^{\circ} 55^{\prime} 0.00^{\prime \prime} \mathrm{E}\right]$, J. Elbert leg., 10.1909, SMF 4579, examined). Strand, 1915: 248, pl. 18, f. 89 (†).

DIAGNOSIS (female). Medium sized (body length: 17.1). Closely related to $H$. nigriventer, but distinguished by the following combination of characters (Figs 179-181): 1. anterior part of median septum narrower than posterior part (about the same width in $H$. nigriventer), 2. epigynal field slightly wider than long (as wide as long or longer than wide in $H$. nigriventer). 3 . first winding of internal duct system extending anteriorly only $25 \%$ of its entire length beyond glandular part (about $50 \%$ in $H$. nigriventer).

REDESCRIPTION. Female. Prosoma length 7.2, width 6.7, anterior width 3.8, opisthosoma length 9.9, width 6.5. Eyes: AME 0.35, ALE 0.57, PME 0.44, PLE 0.54, AME-AME 0.28, AME-ALE 0.07, PMEPME 0.32, PME-PLE 0.55, AME-PME 0.47, ALEPLE 0.47, clypeus height at AME 0.81, at ALE 0.62. Spination: palp: 131, 101, 2121, 1013; legs (legs I missing or regenerated): femur II-III 323, IV 331; patella II-IV 001; tibia II-III 2026, IV 20(1)26; metatarsus II 1014, III 2014, IV 3025. Metatarsus IV ventrally with many bristles along entire length, distally with small dense patch of bristles, ventral metatarsus
III with some bristles very basally. Leg formula: 2143 . Measurements of palp and legs (legs were loose and fragile, therefore only one leg is measured): leg II 31.9 $(8.7,3.9,9.2,8.0,2.1)$. Cheliceral furrow with ca. 90 denticles in elongated patch along the entire cheliceral furrow. Promargin of chelicerae with 3 teeth, retromargin with 4 teeth, one chelicerae with one tiny additional tooth. Palpal claw with 6 teeth, one with one additional small tooth.

Copulatory organ as in diagnosis (Figs 179-181). Epigynal field with anterior bands partly included, two slit sensilla separated 1-2 times their length from field. Lateral lobes at their anterior median part more strongly bulged than in $H$. nigriventer. Internal duct system with plane of first winding orthogonal to optical axis in ventral view (inclined in $H$. nigriventer).

Colouration (Figs 197-198): yellowish-brown with indistinct pattern. Dorsal shield of prosoma with radial markings, eye region darker and bright transversal band at posterior margin; median part of clypeus brighter. Sternum, gnathocoxae and coxae ventrally yellowish brown without pattern except for gnathocoxae with distal half brighter, labium reddish brown with brighter distal margin. Chelicerae reddish brown with distal inner part brighter. Femora spotted, with indistinct median line dorsally in proximal half. Opisthosoma dorsally mottled, posteriorly darker. Opisthosoma ventrally with darker small triangular patch in front of spinnerets and four darker lines (lateral one indistinct) consisting of tiny muscle sigilla. External parts of lateral spinnerets dark.

Male unknown.

DISTRIBUTION. Known only from the type locality: Kabaena Island, Southeast Sulawesi, Indonesia (not Bismarck Archipelago as listed in Platnick 2013) (Fig. 100: arrow).

RELATIONSHIP. Closely related to $H$. nigriventer, but distinctly different in characters listed in the differential diagnosis. Males should prove species status of this form. See also relationship paragraph in $H$. nigriventer.

\section{Heteropoda beroni Jäger, 2005} Fig. 100. of $\Im^{\top}+$ ).

Heteropoda beroni Jäger, 2005: 102, f. 1, 59-81 (description

MATERIAL EXAMINED. INDONESIA: $1 \uparrow$ (PJ 3154), Sulawesi Selantan, Maros Karst, Maros, Bantimurung, Gua Istani Taokala, 5०1'12.00"S, $119^{\circ} 41^{\prime} 2.84^{\prime \prime} \mathrm{E}, 140 \mathrm{~m}$, large fossil cave several hundred meters long, in continuation with the Gua Mimpi, in cave, by hand, Deharveng \& Bedos, 2.8.1988, SULA-014 (MZB).

NOTES. The species was recorded from Bantimurung region already from the caves close to Maros, Pangkajene and Bone [Jäger, 2005]. The body length of the present specimen (prosoma length 16.5, opisthosoma length 20.4) fits in the range as given by Jäger [2005] (Fig. 100: grey circles).

RELATIONSHIPS. Heteropoda beroni is grouped with H. kuekenthali Pocock, 1897 [Jäger, 2005: 107] known from Halmahera. 


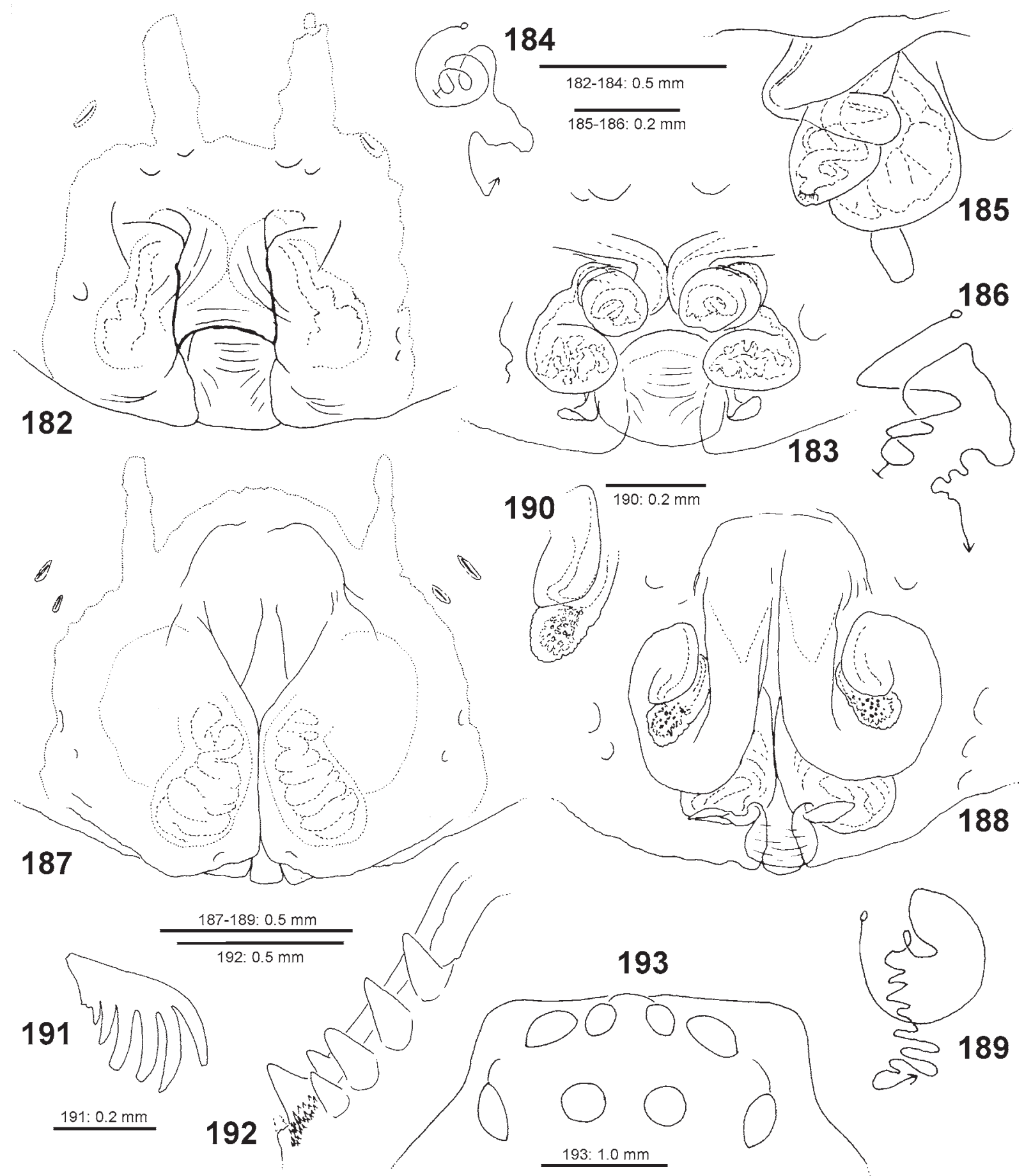

Figs 182-193. Heteropoda spp. 182-186 - H. mediocris, + lectotype from New Guinea. 187-193 - H. analis, $\uparrow$ holotype from New Guinea. 182, 187 - epigyne, ventral; 182, 185, 188, 190 — internal duct system (182, 188 - dorsal; 185, 190 — frontal). 184, 186, 189 schematic course of internal duct system (184, 189 - dorsal; 186 - frontal). 191 - claw of right palp, retrolateral. 192 - chelicerae, ventral. 193 - eye arrangement, dorsal.

Рис. 182-193. Heteropoda spp. 182-186 - H. mediocris, лектотип + $и з$ Новой Гвинеи. 187-193 - H. analis, голотип + из Новой Гвинеи. 182, 187 - эпигина, вентрально; 182, 185, 188, 190 - эндогина (182, 188 - сверху; 185, 190 - спереди). 184, 186, 189 схема канальцев эндогины (184, 189 - сверху; 186 - спереди). 191 - коготок правой пальпы, ретролатерально. 192 - хелицера, вентрально. 193 - расположение глаз, сверху. 
Heteropoda mediocris Simon, 1880

Figs 100, 182-186, 199-200.

Heteropoda mediocris Simon, 1880: 276 (description of $\circ$; 9 syntypes, PJ 3190-3191, , PJ 3190 designated herewith as lectotype [remaining $q$ as paralectotype; see note below], New Guinea, Dorey [=Doreh-Baai, Doré; 0॰51'41.23"S, 134³'43.35"E, $27 \mathrm{~m}$ ], MNHN 1575, examined).

Pandercetes regalis Roewer, 1938: 64, f. 42 (description of ${ }^{\circ}$; holotype + (PJ 2494), New Guinea, Sakoemi [ $1^{\circ} 25^{\prime} 38.74^{\prime \prime} \mathrm{S}, 133^{\circ} 57^{\prime}$ $\left.46.30^{\prime \prime} \mathrm{E}, 2200 \mathrm{~m}\right], 12.3 .1929$, S.A.R. le Prince Leopold, IRSN, examined). Syn.n.

Heteropoda regalis: Jäger 2008b: 247, f. 54-63 (†)

ADDITIONAL MATERIAL EXAMINED. NEW GUINEA: 1 q (PJ 68), Finschhafen [6 $\left.6^{\circ} 36^{\prime} 23.11^{\prime \prime} \mathrm{S}, 147^{\circ} 51^{\prime} 18.40^{\prime \prime} \mathrm{E}, 13 \mathrm{~m}\right]$ (SMF 7623).

NOTE. One female (SMF 7623) was kept together in one vial with another then syntype female. Only one label stated "Java" as locality. In the original publication in contrast, Simon [1880: 277] stated as distribution "Java (coll. E. Simon, reçu du Dr Ploëm); Nouvelle-Guineé: Dorey (Museum, Raffray)". Heteropoda regalis is known from New Guinea only ( 2 +o: Jäger [2008b]). Considering the generally restricted distribution ranges of Heteropoda species and the fact that Simon added in other cases individuals to original series [e.g., Jäger, 2002: 45] it seems most likely that Simon forgot to put a label for the female from New Guinea into the vial. There is a third female in a separate vial identified by Simon as $H$. mediocris, which is not considered as belonging to the syntype series (see note in Heteropoda sp. cf. sumatrana).

The copulatory organs of the name-bearing types of both species in question are very similar, differences (direction of glandular pores, stouter general shape of internal duct system, different shape of epigynal field, etc.) are considered intraspecific variability as known from other species, e.g., from $H$. tetrica [Eusemann \& Jäger, 2009], or $H$. helge [Jäger, 2008b].

The present female represents the third record of this species. Its total body length (12.2) falls slightly below the formerly know size range (12.4-12.9). Other measurements, spination pattern and colouration confirm — besides congruence of copulatory organs conspecifity with $H$. regalis.

DIAGNOSIS. Medium sized (body length of lectotype: 12.2). Diagnostic characters as given for $H$. regalis [see Jäger, 2008b: 249] (Figs 182-186).

REDESCRIPTION. Female (lectotype). Prosoma length 6.2, width 5.7, anterior width 3.2, opisthosoma length 6.0, width 4.4. Eyes: AME 0.31, ALE 0.50, PME 0.37, PLE 0.52, AME-AME 0.22, AME-ALE 0.05, PME-PME 0.31, PME-PLE 0.52, AME-PME 0.41, ALE-PLE 0.41, clypeus height at AME 0.63, at ALE 0.43. Spination: palp: 131, 101, 2121, 1014; legs: femur I 323, II-III 323(333), IV 331; patella I-II 001 , III 001(0), IV 000; tibia I 1016(2036), II-IV 2026; metatarsus I-II 1014, III 2014, IV 3036. Metatarsus IV ventrally with many bristles along entire length, distally with numerous bristles, ventral metatarsus III with only few bristles in basal half. Leg formula: 2143. Measurements of palp and legs: palp 8.8 (2.6, 1.5, 2.0,
$-, 2.7)$, leg I $23.3(6.4,3.0,6.3,5.8,1.8)$, leg II 24.8 (7.0, 3.1, 6.9, 5.9, 1.9), leg III $21.0(5.9,2.5,5.3,4.7$, 1.6), leg IV $21.4(6.4,2.2,5.3,5.8,1.7)$. Cheliceral furrow with 50-60 denticles situated in distinct basal patch. Promargin of chelicerae with 3 teeth, retromargin with 4 teeth. Palpal claw with 6-7 teeth.

Copulatory organ as in diagnosis (Figs 182-186). Epigynal field roughly rectangular, as long as wide with stout anterior bands. One slit sensillum separated by a bit more than its length from epigynal field, the second one included in epigynal field. Internal duct system with glandular part close to the median body axis, glandular pores medio-posteriad. Posterior part of internal duct system touching anterior part, extending distinctly laterally beyond first winding, containing many narrow ducts. Fertilisation ducts separated by about one width of posterior part of internal duct system.

Colouration (Figs 199-200): yellowish- to reddishbrown with indistinct pattern. Dorsal shield of prosoma with faint radial markings, a bright median line behind eyes and indistinct brighter transversal band at posterior margin. Sternum, ventral coxae, gnathocoxae and labium yellowish brown without distinct pattern, labium basally a bit darker, gnathocoxae with brighter distal part. Chelicerae reddish brown with brighter longitudinal bands. Femora with spine patches and spots. Opisthosoma dorsally with bright patch above heart; opisthosoma ventrally with median part darker and four posteriorly converging lines consisting of tiny muscle sigilla. Spinnerets with distal segments brighter.

Male. Unknown.

DISTRIBUTION. Known from New Guinea from three different localities (Sakoemi (type locality of $H$. regalis), Finschhafen, Dorey (type locality of $H$. mediocris)), while Sakoemi and Dorey are considered being situated close together (Fig. 100: black circles).

Heteropoda analis Thorell, 1881

Figs 100, 187-193, 201-202.

Heteropoda analis Thorell, 1881: 380 (description of holotype ․ PJ 2526, New Guinea meridionalis, Fly river [no exact locality known, one point at southern Fly river: $8^{\circ} 17^{\prime} 59.18^{\prime \prime} \mathrm{S}, 142^{\circ} 3^{\prime}$ 28.68"E], L.M. D’Albertis leg., 1875, MCSN, examined).

Heteropoda kobroorica Strand, 1911b: 158, pl. 5, f. 64 (description of $\circ ; 1+$ and 1 immature syntypes; adult + [PJ 240], herewith designated as lectotype, the immature (PJ 241) as paralectotype; Indonesia, Maluku Province, Aru Islands, Kobroor Island, Seltutti $\left[6^{\circ} 23^{\prime} 48.43^{\prime \prime} \mathrm{S}, 134^{\circ} 46^{\prime} 24.00^{\prime \prime} \mathrm{E}, 1 \mathrm{~m}\right]$, in forest, H. Merton, 3.5.1908, SMF 4580, examined). Syn.n.

ADDITIONAL MATERIAL EXAMINED. NEW GUINEA: 1 + (PJ 464), Central New Guinea, Coll. Reimoser (NHWM).

NOTE. Copulatory organs of all three females examined are congruent. Type specimen of $H$. analis is very pale, most likely due to the age of the material. Therefore the type of $H$. kobroorica is used for description of the colouration. The female (PJ 464) from Central New Guinea shows a similar but bit paler colouration pattern as the holotype of $H$. kobroorica.

DIAGNOSIS. Heteropoda analis is medium sized (body length: 13.9-16.1) and closely related to other 
species from East Indonesia and Papua New Guinea: H. rubra Chrysanthus, 1965, H. dasyurina (Hogg, 1914), H. atriventris Chrysanthus, $1965, H$. cyanognatha Thorell, 1881, H. teranganica Strand, 1911 and $H$. sarotoides Järvi, 1911. Females have a narrow median septum converging anteriorly and similar internal duct systems. Heteropoda analis may be recognised by the following combination of characters (Figs 187190): 1. epigynal field with anterior bands widely separated with semi-circular part interjacent, 2. lateral lobes touching each other along the median line in posterior part, anterior margins of lateral lobes leaving a Vshaped area, 3. internal duct system with first part parallel, one coil until glandular parts and with glandular pores situated on separated structure.

REDESCRIPTION. Female (holotype of H. analis). Prosoma length 5.4, width 5.2, anterior width 2.6, opisthosoma length 8.5, width 5.4. Eyes (Fig. 193): AME 0.32, ALE 0.48, PME 0.33, PLE 0.48, AMEAME 0.16, AME-ALE 0.06, PME-PME 0.32, PMEPLE 0.44, AME-PME 0.40, ALE-PLE 0.42, clypeus height at AME 0.56, at ALE 0.38. Spination: palp: 131, 101, 2121, 1014; legs: femur I-III 323, IV 331; patella I-II 001, III-IV 000; tibia 2026; metatarsus I-II 1014, III 2014, IV 3036. Metatarsus IV ventrally with many bristles along entire length, metatarsus III ventrally with several bristles in proximal two third. Leg formula: 2143. Measurements of palp and legs: palp 8.5 (2.4, $1.2,2.1,-, 2.8)$, leg I $23.9(6.7,2.8,7.1,5.6,1.7)$, leg II $26.3(7.6,2.9,7.8,6.1,1.9)$, leg III $20.7(6.2,2.2,6.0$, $4.7,1.6)$, leg IV $22.4(6.6,2.1,6.1,5.9,1.6)$. Cheliceral furrow with 40-45 denticles in basal patch (Fig. 192). Promargin of chelicerae with 3 teeth, retromargin with 4 teeth. Palpal claw with 6 teeth (Fig. 191).

Copulatory organ as in diagnosis (Figs 187-190). Epigynal field as long as wide with narrow anterior bands. Four slit sensilla separated by less than one and by 1.5-2 times of their length from epigynal field respectively. Internal duct system with first winding dominant, covering largely posterior part. Fertilisation ducts separated by about one width of first parallel part of internal duct system.

Colouration (specimen faded; Figs 201-202): pale yellowish-brown. Dorsal shield of prosoma with distinctly marked fovea and bright patch behind. Ventral coxae, sternum and gnathocoxae without pattern. Chelicerae reddish brown. Femora with distinct spine patches and additional spots. Opisthosoma dorsally with dark transversal bar at posterior end. Opisthosoma ventrally with four lines consisting of tiny muscle sigilla, the inner two more distinct.

Male. Unknown.

VARIATION. Spination: femora III 333, patellae I-II 000. Palpal claw with 5 teeth and one additional small tooth.

DISTRIBUTION. Known from Central New Guinea and from Aru Islands (Fig. 100: black squares).

The following species are considered nomina dubia, as from the original descriptions no characteristics or diagnostic features can be recognised. Since in the regions of the particular type localities the diversity of the genus Heteropoda is very high and the colour patterns of immature specimens is sometimes strikingly different than that known from adults there is only a low chance to find the right species for the particular available name.

H. annulipoda Strand, 1911 nomen dubium from Aru Islands.

H. bimaculata Thorell, 1878 nomen dubium from Amboina (Ambon).

H. bivittata Thorell, 1887 nomen dubium from $\mathrm{Su}-$ lawesi (Celebes).

H. panaretiformis Strand, 1906 nomen dubium from Sumatra.

\section{Species misplaced in Heteropoda}

\section{Barylestis manni (Strand, 1906) comb.n.}

Torania manni Strand, 1906: 68 (description of $\circ$; $q$ syntypes, Nigeria, Lagos [6²6’45.83"N, 3²4’42.90"E, 7 m], Mann leg., SMNS, destroyed in 2nd world war acc. to Renner [1988: 323]). Heteropoda manni: Jäger, 2001 (transfer by synonymisation of Torania with Heteropoda).

NOTES. Although Jäger [2002: 36] noted that all African species listed under the genus Torania are in fact belonging to the genus Barylestis, the present species was not expressly listed in that publication as new combination, neither in the text nor in the abstract. Since the type is lost and from the original description a diagnosis cannot be given, the identity of this species remains unresolved. From the distribution range of other Barylestis species [Jäger, 2008c: fig. 18] several species could be theoretically synonyms of $B$. manni. From the total length (33 mm) of $B$. manni it may be a synonym of $B$. occidentalis (Simon, 1887), the largest Barylestis species (total length: $20-37 \mathrm{~mm}$ ). As African Sparassidae are not thoroughly revised like, for instance, Asian representatives, the species is not synonymised here. May be a designation of a neotype from Lagos may help to clear the situation.

\section{Pseudopoda aureola (He et $\mathrm{Hu}, 2000)$ comb.n.}

Heteropoda aureola $\mathrm{He} \& \mathrm{Hu}, 2000:$ 17, f. 1-2 (description of holotype $\sigma^{7}$, China, Hainan Province, Dongle County, Jianfengling State Natural Reserve, $18^{\circ} 24^{\prime} \mathrm{N}, 108^{\circ} 48^{\prime}$ E, S.L. Li, 8.4.1980, TNHM, not examined)

NOTES. After a revision of a large amount of Heteropoda species I cannot recognise any typical features of the male palp in the original drawings of $\mathrm{He} \& \mathrm{Hu}$ [2000]. The RTA arising medially to distally with a bifid apex point to congenerity with Pseudopoda Jäger, 2000. Moreover the original authors compared the species with $P$. virgata (Fox, 1936). Therefore the species is transferred to this genus, although a definite characterisation appears only possible with original type material or additional material from the type locality. 

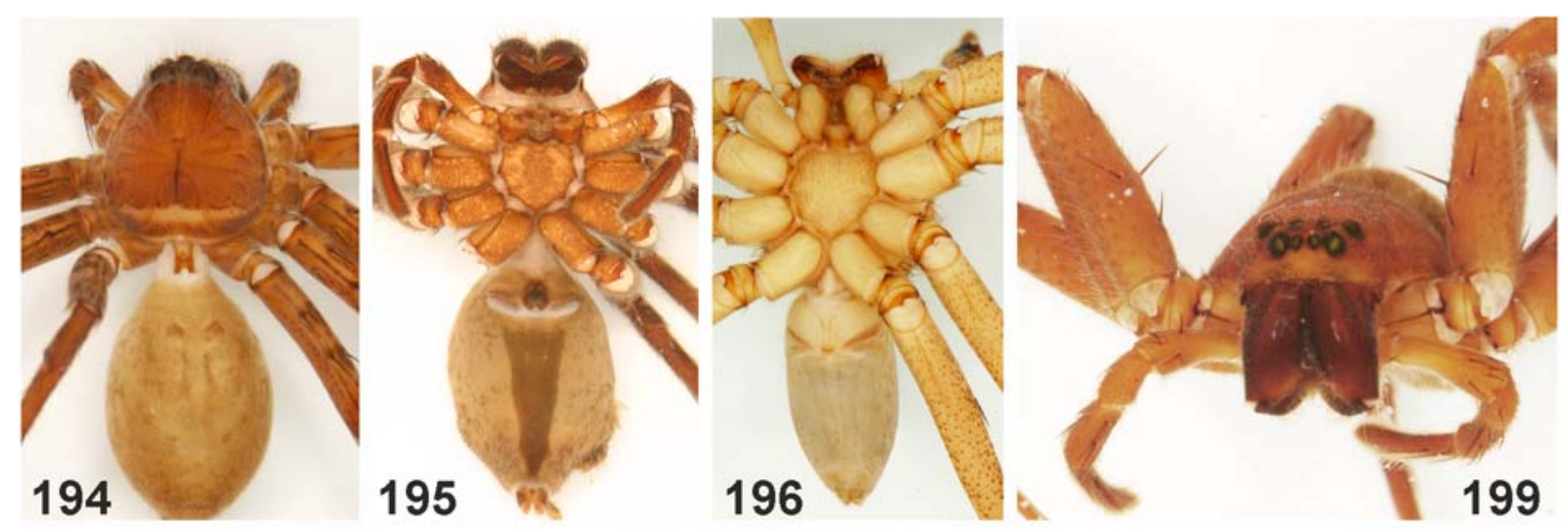

194
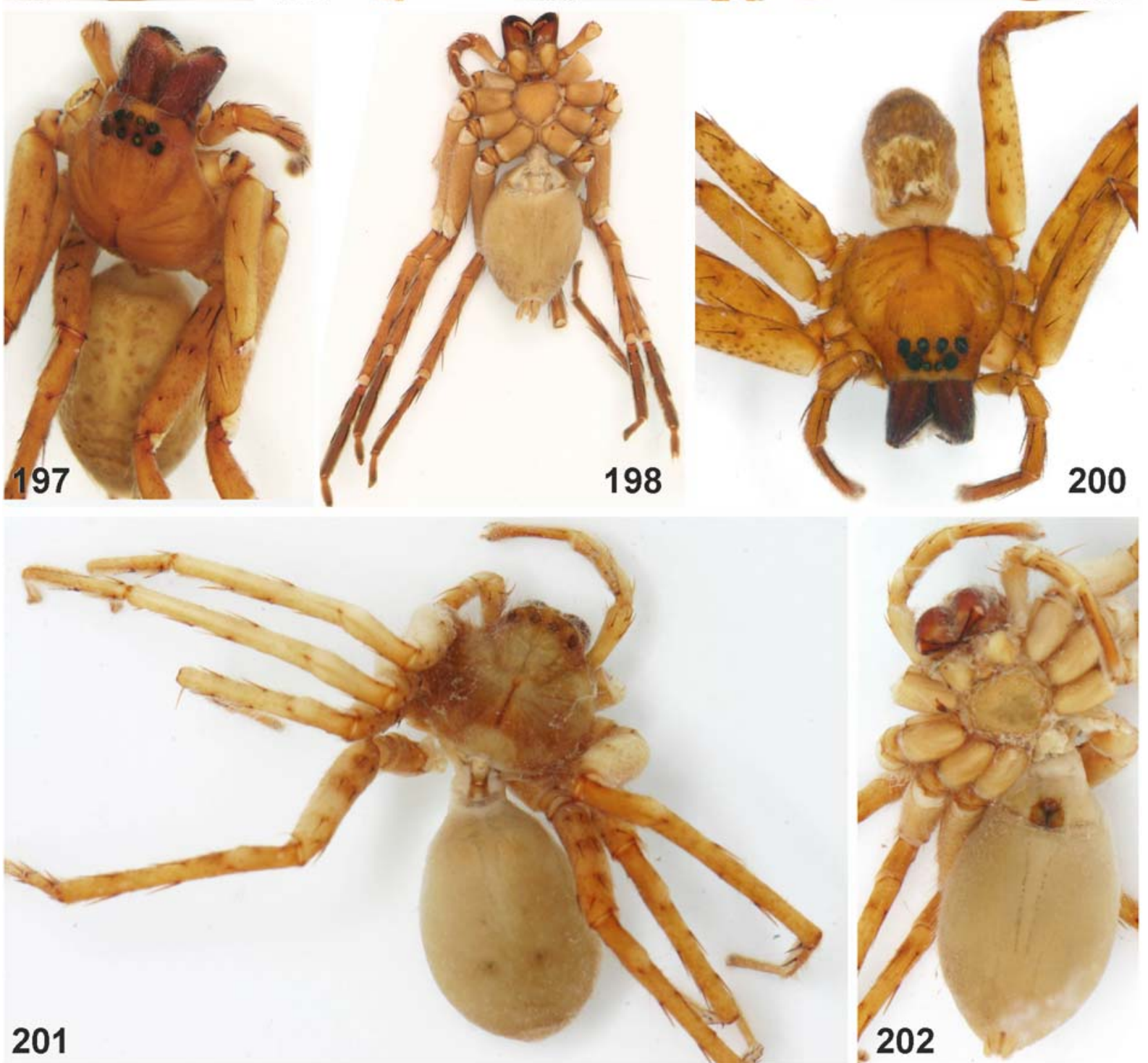

Figs 194-202. Habitus of preserved spiders. 194-196 - Heteropoda nigriventer from Sulawesi (194 — + , PJ 3203; 195 — 9 , PJ 3197; $196-0^{7}$ holotype of $H$. laurae). 197-198 - H. kabaenae from Sulawesi, 9 holotype. 199-200-H. mediocris from New Guinea (199 - + lectotype; 200 - + holotype of H. regalis). 201-202 - H. analis, + holotype from New Guinea.

Рис. 194-202. Габитус фиксированных пауков. 194-196 - Heteropoda nigriventer из Сулавеси (194 — + , РJ 3203; 195 — , РЈ 3197; 196 — голотип O’ H. laurae). 197-198 - H. kabaenae из Сулавеси, голотип ․ 199-200 — H. mediocris из Новой Гвинеи (199 лектотип $+; 200-$ голотип + H. regalis). 201-202-H. analis, голотип + из Новой Гвинеи. 


\author{
Pseudopoda shillongensis (Sethi et Tikader, 1988) \\ comb.n.
}

Heteropoda shillongensis Sethi \& Tikader, 1988: 19, f. 70-75 (description of $\sigma^{7}$ and subadult ${ }^{\circ}$; holotype subadult(?) + , India,

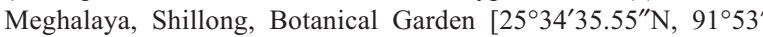
12.76"E, 1485]; $10 \sigma^{7} \sigma^{7}$ paratypes (plus 200 immatures), India, Meghalaya, Shillong, Malki [253' $46.12^{\prime \prime} \mathrm{N}, 91^{\circ} 53^{\prime} 30.30^{\prime \prime} \mathrm{E}, 1560$ $\mathrm{m}] ; 10$ + 10 paratypes, with same data as for holotype; NZSI, not examined)

NOTES. Sethi \& Tikader [1988] illustrate a palp of an adult male in prolatero-ventral view and female preepigyne from a subadult specimen. They discuss relationships in comparison with Bhutaniella sikkimensis (Gravely, 1931) (sub Meteropoda [sic!] sikkimensis). The light colouration with dark dots points to both genera, Pseudopoda and Bhutaniella. The palp with the non-filiform embolus reaching barely the distal tegulum and the medially arising RTA are clearly indicating congenerity with Pseudopoda prompta, the type species of the genus.

Pseudopoda straminiosa (Kundu, Biswas et Raychaudhuri, 1999) comb.n.

Heteropoda straminiosa Kundu et al., 1999: 98, f. A, 1-6 (description of holotype + , India, West Bengal, Jalpaiguri, Buxa Tiger Reserve, South Volka [= South Bhalka forest; $26^{\circ} 31^{\prime} 22.57^{\prime \prime} \mathrm{N}$, $89^{\circ} 50^{\prime} 29.60^{\prime \prime} \mathrm{E}, 70 \mathrm{~m}$ ], NZSI, not examined).

NOTES. From the original illustration especially of the epigyne and vulva it is clear that this species belongs to Pseudopoda, therein most likely to the prompta-group [for diagnoses see Jäger, 2001: 34 (German) or 2008a: 516 (English)]. This assumption is supported by the spotted femora [Kundu et al., 1999: fig. A], characteristic for many Pseudopoda species (although exceptional in the prompta-group) and the gross distribution range of the genus. Although the species could tentatively be assigned to a species-group no statements on the identity or phylogenetic relationship of this form can be made.

Spariolenus buxa (Saha, Biswas et Raychaudhuri, 1995) comb.n.

Heteropoda acuta Saha et al., 1994: 43, f. 1-5 (preoccupied by $H$. acuta Davies, 1994 from Australia).

Heteropoda buxa Saha et al., 1995: 16, f. 1-2 (description of holotype $\sigma^{7}$, India, West Bengal, Jalpaiguri, Buxa Tiger Reserve, South Raydak [263' $53.99^{\prime \prime} \mathrm{N}, 8^{\circ} 44^{\prime} 59.76^{\prime \prime} \mathrm{E}, 70 \mathrm{~m}$ ], NZSI, not examined)

NOTES. According to the shape and strength of the embolus, the strongly reduced conductor (both characters similar to $S$. tigris Simon, 1880), the stout shape of the RTA and the presence of five posterior cheliceral teeth this species assumingly belongs to the genus Spariolenus Simon, 1880. Moradmand \& Jäger [2011] described two more species with males known. Emboli as well as conductors of those were considerably longer than those of S. tigris and S. buxa.
Gnathopalystes denticulatus (Saha et Raychaudhuri, 2007) comb.n.

Heteropoda denticulata Saha \& Raychaudhuri, 2007: 82, f. 16 (description of holotype 9 , India, West Bengal, Jalpaiguri, Jaldapara Wildlife Sanctuary, Kunjanagar $\left[26^{\circ} 32^{\prime} 57.97^{\prime \prime} \mathrm{N}, 89^{\circ} 15^{\prime} 8.48^{\prime \prime} \mathrm{E}\right.$, $70 \mathrm{~m}$ ], EZC 0002-03, not examined).

NOTES. From the original illustrations of Saha \& Raychaudhuri [2007] it is most likely that this species belongs to Gnathopalystes Rainbow, 1899. Evidence comes from the chelicerae with two anterior teeth and denticles over entire length of cheliceral furrow, a unique character of this genus [see Jäger, 1998: fig. 3g; Jäger \& Kunz, 2005: fig. 200]. Eye arrangement does not look like the typical arrangement as known from Gnathopalystes [see Jäger, 1998: fig. 2d; Jäger \& Kunz, 2005: figs 198-199]. However, cheliceral dentition and similarity of epigynal and vulval structures with known Gnathopalystes species justify this transfer.

Olios bhattacharjeei (Saha et Raychaudhuri, 2007) comb.n.

Heteropoda bhattacharjeei Saha \& Raychaudhuri, 2007: 83, f. 7-11 (description of holotype $\sigma^{7}$, India, West Bengal, Jalpaiguri,

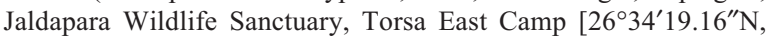
89 $15^{\prime} 19.91^{\prime \prime}$ E, 70 m], EZC 0003-03, not examined).

NOTES. Saha \& Raychaudhuri [2007] described two species (Heteropoda bhattacharjeei and Olios jaldaparaensis) which clearly belong both in the genus Olios Walckenaer, 1837. They did not mention any reason why one should belong to Heteropoda. According to the two retrolateral tibial apophyses, known in Olios tener (Thorell, 1891) or O. sanguinifrons (Simon, 1906) [see Jäger et al., 2002] both species seems to belong into this species group.

\section{Olios debalae (Biswas et Roy, 2005) comb.n.}

Heteropoda debalae Biswas \& Roy, 2005: 199, f. 1-3 (description of $q$; holotype + , India, Kolkata, Bahala near Debalay [22 $29^{\prime} 48.34^{\prime \prime} \mathrm{N}, 88^{\circ} 18^{\prime} 34.01^{\prime \prime} \mathrm{E}, 10 \mathrm{~m}$ ], at night, in room, reg. no. $5577 / 18]$ and 1 paratype + , India, West Bengal, Sunderban, Dist. South24-Paraganas, Sagar Island close to Omkarnath Ashram $\left[21^{\circ} 38^{\prime} 3.68^{\prime \prime} \mathrm{N}, 88^{\circ} 4^{\prime} 42.12^{\prime \prime} \mathrm{E}, 5 \mathrm{~m}\right.$ ], reg. no. 5581/18, NZSI 700 053, not examined).

NOTES. Illustrations given by Biswas \& Roy [2005] show clearly a female of an Olios species (group close to $O$. versicolor). Not only traits of the female copulatory organ but also illustration of the dorsal habitus (eye region dark, opisthosoma with dark margin) as well as the description of the colouration (esp. "legs ... with alternative bands of yellow and black" points to this Olios species group [see also Jäger, 2005: figs 14, and Jäger et al., 2002: figs 44-48). Unfortunately, details for a proper characterisation and recognition of this species within the diverse species group are missing. 


\section{Misplaced in Heteropoda, but of unknown systematic position:}

\section{Heteropoda camelia Strand, 1914}

Heteropoda camelia Strand, 1914: 812 (description of holotype ${ }^{\circ}$, Colombia, Angelopolis $\left[6^{\circ} 6^{\prime} 43.70^{\prime \prime} \mathrm{N}, 75^{\circ} 42^{\prime} 35.12^{\prime \prime} \mathrm{W}\right]$, La Camelia, 1820 [m], Central Cordillera, deposition unknown, not examined).

NOTES. According to the original description $H$. venatoria is not concerned in this case. The little size of $8 \mathrm{~mm}$ total length, the rhomboid shape of the epigynal median field and the fact that Strand compares the species to Sparianthina pumilla (Keyserling, 1880) are evidences that it is not $H$. venatoria and no Heteropo$d a$ species at all. Unfortunately, the textual description gives only little hints for a clear identification of the genus. The examination of the type or syntopic material is the only chance to clear the taxonomic status of this nominal species.

ACKNOWLEDGEMENTS. I would like to thank all curators of the museums and collections who sent material for this study (see list in "Material \& Methods") and all collectors providing specimens especially Steffen Bayer (SMF), Wimolwan Chotwong (Bangkok), David Court (Singapore), Louis Deharveng (MNHN), Sergei Golovatch (Moscow), Charles Haddad (Bloemfontein), Siegfried Huber (Oberuhldingen), Ondrej Kosulic (Brno), Damir Kovac (SMF), Andre Leetz (Walheim), Jochen Martens (Mainz), Wolfgang Schawaller (Stuttgart), Frank Schneider (Ludwigshafen), Peter Schwendinger (Geneva), Helmut Steiner (Hanau), Kathrin Stenchly (Kassel), Wolfgang Thielen, Remy Van Herck (Lop Buri), Jean Michel Verdez (Lievin), Thomas Ziegler (Cologne). Joachim Holstein (SMNS) gave information on the types in the museum in Stuttgart. Norm Platnick (AMNH) provided papers of Indian journals. Thomas Lehmann (SMF) helped with the translations of French descriptions of Eugene Simon. Edi Stoeckli and Urs Wuest (Basel) provided information on the Sarasin travels in $\mathrm{Su}$ lawesi, Cahyo Rahmadi (Cibinong) on coordinates of caves in the Maros Karst in Sulawesi. Thanks to Yuri Marusik (Magadan) for involving to this special issue and for his careful correcting and editing of the manuscript. Travels to the MNHN, Paris and NHM, London have been funded by the European Union program SYNTHESYS.

\section{References}

Baroni Urbani C., Stemmler O., Wittmer W., Würmli M. 1973. Zoologische Expedition des Naturhistorischen Museums Basel in das Königreich Bhutan // Verhandlungen der Naturforschenden Gesellschaft Basel. Vol.83. No.2. P.319-336.

Bayer S., Jäger P. 2009. Heteropoda species from limestone caves in Laos (Araneae: Sparassidae: Heteropodinae) // Zootaxa. No.2143. P.1-23.

Biswas B., Roy R. 2005. Description of a new species of giant crab-spider (Araneae: Heteropodidae) from India // Records of the zoological Survey of India. Vol.105. Nos.3-4. P.199-201

Biswas, V., Raychaudhuri D. 2005. Huntsman spiders of Bangladesh: genus Heteropoda Latreille and Olios Walckenaer (Ara- neae: Sparassidae) // Records of the zoological Survey of India, Vol.104. Nos.3-4. P.103-109.

Bösenberg W., Strand E. 1906. Japanische Spinnen // Abhandlungen der Senckenbergischen naturforschenden Gesellschaft. Vol.30. P.93-422.

Dierkens M. 2011. A propos d'Heteropoda belua Jäger, Sparassidae (Araneae) troglophile de Bornéo // Bulletin Mensuel de la Société Linnéenne de Lyon. Vol.80. P.119-121.

Eusemann P., Jäger P. 2009. Heteropoda tetrica Thorell, 1897 variation and biogeography with emphasis on copulatory organs (Arachnida: Araneae: Sparassidae) // Kropf C., Horak P. (eds.). Towards a natural history of arthropods and other organisms. In memoriam Konrad Thaler. Contributions to Natural History, Bern. Vol.12. P.499-516.

Fritzsche I., Zompro O. 2008. Heteropoda maxima Jäger 2001 die größte Jagdspinne // Arthropoda. Vol.16. No.1. P.74.

He S., Hu J.L. 2000. A new species of the genus Heteropoda from Hainan Province, China (Araneae: Sparassidae) // Acta arachnologica sinica. Vol.9. P.17-19.

Jäger P. 1998. First results of a taxonomic revision of the SE Asian Sparassidae (Araneae) // Selden P.A. (ed.). Proceedings of the 17th European Colloquium of Arachnology, Edinburgh, 1997. Burnham Beeches, Bucks: British Arach. Soc. P.53-59.

Jäger P. 2000. Heteropoda parva n. sp. and H. martusa n. sp. primitive or derived Heteropoda species? (Araneae: Sparassidae: Heteropodinae) // Mitteilungen des International Entomologischen Vereins, Frankfurt. Vol.25. Nos.3-4. P.195205.

Jäger P. 2001. Diversität der Riesenkrabbenspinnen im Himalaya. Über eine Radiation zweier Gattungen in den Schneetropen (Araneae: Sparassidae: Heteropodinae) // Courier Forschungsinstitut Senckenberg. Vol.232. P.1-136.

Jäger P. 2002. Heteropodinae: transfers and synonymies (Arachnida: Araneae: Sparassidae) // Acta Arachnologica. Vol.51. No.1. P.33-61.

Jäger P. 2005. New large-sized cave-dwelling Heteropoda species from Asia, with notes on their relationships (Araneae: Sparassidae: Heteropodinae) // Revue Suisse de Zoologie. T.112. Fasc.1. P.87-114

Jäger P. 2007. Spiders (Araneae) from Laos with descriptions of new species // Acta Arachnologica. Vol.56. No.1. P.29-58.

Jäger P. 2008a. Three new Pseudopoda species from northern India (Araneae: Sparassidae: Heteropodinae) // Revue Suisse de Zoologie. T.115. Fasc.3. P.515-526.

Jäger P. 2008b. Revision of the huntsman spider genus Heteropo$d a$ Latreille 1804: species with exceptional male palpal conformations (Araneae: Sparassidae: Heteropodinae) // Senckenbergiana biologica. Vol.88. No.2. P.239-310.

Jäger P. 2008c. Barylestis Simon 1910 - first record in Asia with comments on its zoogeography (Araneae: Sparassidae: Heteropodinae) // Arthropoda Selecta. Vol.17. No.1-2. P.105-110.

Jäger P., Bayer S. 2009. The male of Heteropoda ocyalina (Simon 1887) (Araneae: Sparassidae: Heteropodinae) // Bulletin of the British Arachnological Society. Vol.14. Pt.9. P.368-370

Jäger P., Gao J., Fei R. 2002. Sparassidae in China 2. Species from the collection in Changchun. (Arachnida: Araneae) // Acta Arachnologica. Vol.51. No.1. P.23-31.

Jäger P., Kunz D. 2005. An illustrated key to genera of African huntsman spiders (Arachnida, Araneae, Sparassidae) // Senckenbergiana biologica. Vol.85. No.2. P.163-213.

Jäger P., Ono H. 2000. Sparassidae of Japan. I. New species of Olios, Heteropoda and Sinopoda with remarks on known species (Arachnida: Araneae) // Acta Arachnologica. Vol.49. No.1. P.41-60.

Jäger P., Praxaysombath B. 2009. Spiders from Laos: new species and new records (Arachnida: Araneae) // Acta Arachnologica. Vol.58. No.1. P.27-51.

Jäger P., Rheims C.A., Labarque F.M. 2009. On the huntsman spider genera Sparianthina BANKS 1929 and Anaptomecus SIMON 1903 from South and Central America (Araneae: Sparassidae) // Zookeys. Vol.16. P.115-147.

Jäger P., Yin C.M. 2001. Sparassidae in China. 1. Revised list of known species with new transfers, new synonymies and type 
designations (Arachnida: Araneae) // Acta Arachnologica. Vol.50. No.2. P.123-134

Karsch F. 1881. Diagnoses Arachnoidarum Japoniae // Berliner entomologische Zeitschrift. Bd.25. S.35-40.

Kundu M., Biswas V., Raychaudhuri D. 1999. New huntsman spiders (Heteropodidae: Araneae) from Buxa Tiger Reserve, Jalpaiguri, West Bengal // Journal of the Bombay Natural History Society. Vol.96. P.98-105.

Koch C.L. 1845. Die Arachniden. Nürnberg. Zwölfter Band. S.1166.

Koch L. 1878. Japanesische Arachniden und Myriapoden // Verhandlungen der zoologisch-botanischen Gesellschaft Wien. Bd.27. S.735-798.

Li A.H. 1991. Two new species of spiders of the genus Heteropoda from China (Araneae: Heteropodidae) // Acta Agriculturae Universitatis Jiangxiensis. Vol.13. P.366-369.

Linnaeus C. 1767. Systema naturae per regna tria naturae, secundum classes, ordines, genera, species, cum characteribus differentiis, synonymis, locis. Editio duodecima, reformata. Holmiae. Vol.1. No.2. P.533-1327.

McCook H.C. 1878. Note on the probable geographical distribution of a spider by the trade winds // Proceedings of the Academy of Natural Sciences of Philadelphia. Vol.1878. P.136147.

Merian P. 1911. Die Spinnenfauna von Celebes. Beiträge zur Tiergeographie im Indo-Australischen Archipel // Zoologische Jahrbücher, Abt. Systematik. Bd.31. S.165-354.

Moradmand M., Jäger P. 2011. A review on the huntsman spider genus Spariolenus Simon 1880 (Araneae: Sparassidae: Heteropodinae) in Iran, with description of four new species // Zootaxa. No.2910. P.46-62.

Nishikawa T., Sattmann H. 2001. List of Dr. Albrecht von Roretz's collection of Japanese animals made about 120 years ago, compiled from the catalogues of Naturhistorisches Museum Wien // Bulletin of the Nagoya University Museum. Vol.17. P.33-44.

Ono H. 2009. The Spiders of Japan with keys to the families and genera and illustrations of the species. Kanagawa: Tokai University Press. 738 p.

Platnick N.I. 2013. The world spider catalog, version 14.0. American Museum of Natural History // online at http://research. amnh.org/entomology/spiders/catalog/index.html DOI: 10.5531/ db.iz.0001.

Pocock R.I. 1897. Spinnen (Araneae) // Kuekenthal. Ergebnisse einer zoologische Forschungsreise in dem Molukken und Borneo. Abhandlungen der Senckenbergischen naturforschenden Gesellschaft. Bd.23. S.591-629.

Pocock R.I. 1900. The fauna of British India, including Ceylon and Burma. Arachnida. London. 279 p.

Renner F. 1988. Liste der im Krieg vernichteten Typen des Königlichen Naturalienkabinetts in Stuttgart // Haupt J. (ed.). XI Europäisches Arachnologisches Colloquium 1988, Berlin. TUB Dokumentation Kongresse und Tagungen. Vol.38. P.319-329.

Roewer C.F. 1938. Araneae // Résultats scientifiques du Voyage aux indes orientales néerlandaises de la SS. AA. RR. le Prince et la Princesse Leopold de Belgique. Mémoires du royal Musée d'histoire naturelle de Belgique. Vol.3. No.19. P.1-94.

Saha S., Raychaudhuri D. 2007. Heteropodine spiders (Sparassidae: Araneae) from Jaldapara Wildlife Sanctuary, Jalpaiguri, West Bengal // Journal of the Bombay Natural History Society. Vol.103. P. 82-86.
Saha S., Biswas V., Raychaudhuri D. 1994. Heteropodidae and Lycosidae of Buxa Tiger Reserve, West Bengal // Acta arachnologica. Vol.43. P.43-48.

Saha S., Biswas V., Raychaudhuri D. 1995. A new name for Heteropoda acuta Saha, Biswas et Raychaudhuri, 1994 (Araneae: Heteropodidae) // Acta arachnologica. Vol.44. P.15-16.

Sethi V.D., Tikader B.K. 1988. Studies on some giant crab spiders of the family Heteropodidae from India // Records of the zoological Survey of India; Miscellaneous Publication, Occasional Paper. Vol.93. P.1-94.

Simon E. 1880. Révision de la famille des Sparassidae (Arachnides) // Actes de la Société Linnéenne de Bordeaux. Vol.34. P.223-351.

Simon E. 1887. Etude sur les arachnides de l'Asie méridionale faisant partie des collections de l'Indian Museum (Calcutta). I. Arachnides recueillis à Tavoy (Tenasserim) par Moti Ram // Journal of the Asiatic Society of Bengal. Vol.56. P.101-117.

Song D.X., Zhu M.S., Chen J. 1999. The Spiders of China. Hebei Science and Technology Publishing House, Shijiazhuang. 640 p.

Strand E. 1906. Tropisch-afrikanische Spinnen des Kgl. Naturalienkabinetts in Stuttgart // Jahreshefte des Vereins für vaterländische Naturkunde in Württemberg. Bd.62. S.13-103.

Strand E. 1907. Vorläufige Diagnosen süd- und ostasiatischer Clubioniden, Ageleniden, Pisauriden, Lycosiden, Oxyopiden und Salticiden // Zoologischer Anzeiger. Bd.31. S.558-570.

Strand E. 1909. Süd- und ostasiatische Spinnen. II. Fam. Clubionidae. Fam. Salticidae // Abhandlungen der naturforschenden Gesellschaft zu Görlitz. Bd.26. S.1-128.

Strand E. 1911a. Vorläufige Diagnosen neuer Spinnen, insbesondere aus der Südsee, des Senckenbergischen Museums // Archiv für Naturgeschichte. Bd.77. H.1-2. S.202-207.

Strand E. 1911b. Araneae von den Aru- und Kei-Inseln // Abhandlungen der senckenbergischen naturforschenden Gesellschaft. Bd.34. S.127-199.

Strand E. 1914. Spinnen der Familien: Sparassidae, Lycosidae, Sicaridae, und Pholcidae aus Kolombien // Voyage d'exploration scientifique en Columbie, par O. Fuhrmann et Eug. Mayor. Mémoires de la Société Sciences Naturelle de Neuchâtel. Vol.5. P.810-820.

Strand E. 1915. Indoaustralische, papuanische und polynesische Spinnen des Senckenbergischen Museums, gesammelt von Dr E. Wolf, Dr J. Elbert u // Wissenschaftliche Ergebnisse der Hanseatischen Südsee-Expedition 1909. Abhandlungen der senckenbergischen naturforschenden Gesellschaft. Bd.36. H.2. S.179-274.

Thorell T. 1878. Studi sui ragni Malesi e Papuani. II. Ragni di Amboina raccolti Prof. O. Beccari // Annali del Museo civico di storia naturale di Genova. T.13. P.1-317.

Thorell T. 1881. Studi sui Ragni Malesi e Papuani. III. Ragni dell'Austro Malesia e del Capo York, conservati nel Museo civico di storia naturale di Genova // Annali del Museo civico di storia naturale di Genova. T.17. P.1-727.

Thorell T. 1891. Spindlar från Nikobarerna och andra delar af södra Asien // Konglige Svenska Vetenskaps-Academiens Handlingar. Vol.24. No.2. P.1-149.

Tikader B.K. 1977. Studies on spider fauna of Andaman and Nicobar islands, Indian Ocean // Records of the Zoological Survey of India. Vol.72. P.153-212.

Yaginuma T. 1961. Spiders from the Tokara islands // Bulletin of the Osaka Museum of Natural History. Vol.13. P.82-86.

Responsible editor Yu.M. Marusik 